\title{
Forbidden islands. The absence of endemics among the insular non-volant terrestrial mammalian fauna of the Red Sea
}

\author{
Marco Masseti ${ }^{1}$, Giuseppe De Marchi ${ }^{2}$, Giorgio Chiozzi ${ }^{2,3 *}$
}

\begin{abstract}
The Red Sea is a land-locked sea that is globally significant in terms of the unique biodiversity and endemism of its marine species. In contrast, the terrestrial biodiversity on its islands is poor and mainly composed of species present also on the mainland. To profile the non-volant terrestrial mammalian fauna, we reviewed all available records in the literature and report some recent captures; in particular, we point out two additional species from the Dahlak archipelago: the Northeast African spiny mouse (Acomys cahirinus) and a still undetermined shrew (Crocidura sp.). As far as we know, the only endemic vertebrates are three species of snake (Squamata, Serpentes) and perhaps one gazelle (Gazella arabica). The composition of the insular mammalian fauna of the Red Sea is olygotypic, consisting of only a few taxa, mostly anthropochorous, that are shared with the mainland of eastern Africa and/or western Arabia, and which are repeated monotonously on the few islands inhabited by mammals. A lack of endemic mammals can be explained as the result of the only recent connection of almost all the islands with the mainland during the Last Glacial Maximum and by the harsh climatic conditions that allow the survival of only a few xeric specialists.
\end{abstract}

Key words: Commensal rodents, Crocidura, Gazella, Ichneumia albicauda, insular mammals, Nanger soemmerringii, Red Sea.

Riassunto - Isole proibite. L'assenza di endemismi tra i mammiferi terrestri insulari non volatori del Mar Rosso.

Racchiuso da terre, il Mar Rosso è un mare d'importanza globale per la sua biodiversità marina e per il numero di endemismi. Al contrario, la biodiversità terrestre insulare è scarsa e prevalentemente costituita da specie presenti anche sulla terraferma. Per descrivere la composizione della fauna terrestre a mammiferi abbiamo esaminato tutte le osservazioni rintracciabili in letteratura e riportato alcune recenti catture. In particolare, segnaliamo due ulteriori specie dall'arcipelago delle Dahlak: il topo spinoso egiziano (Acomys cahirinus) e un toporagno ancora indeterminato (Crocidura sp.). Sulle isole del Mar Rosso

\footnotetext{
${ }^{1}$ Department of Biology, University of Florence, Via del Proconsolo 12, 50122 Florence, Italia

E-mail: marco.masseti@unifi.it

${ }^{2}$ Department of Earth and Environmental Sciences, University of Pavia, Via A. Ferrata 1, 27100 Pavia, Italia

E-mail: dromasardeola@gmail.com

${ }^{3}$ Museo di Storia Naturale di Milano, Corso Venezia 55, 20121 Milano, Italia

* Corresponding author: giorgio.chiozzi@comune.milano.it

(C) 2015 Marco Masseti, Giuseppe De Marchi, Giorgio Chiozzi
}

Received: 13 July 2015

Accepted for publication: 25 September 2015 non vivono mammiferi terrestri endemici e alla luce delle conoscenze attuali, gli unici vertebrati endemici non volatori includono tre specie di serpenti (Squamata, Serpentes) e, forse, una gazzella (Gazella arabica). La composizione della fauna di mammiferi insulari del Mar Rosso è oligotipica, costituita da pochi taxa, per lo più antropocori, che sono condivisi con le faune continentali in Africa orientale e/o in Arabia occidentale, e che si ripetono con monotonia sulle poche isole abitate da mammiferi. La mancanza di mammiferi endemici può essere spiegata come conseguenza del recente collegamento di quasi tutte le isole con la terraferma durante l'ultimo massimo glaciale e come effetto delle condizioni climatiche severe che permettono solo la sopravvivenza di pochi specialisti xerofili.

Parole chiave: Crocidura, Gazella, Ichneumia albicauda, mammiferi insulari, Mar Rosso, Nanger soemmerringii, roditori commensali.

\section{INTRODUCTION}

The Red Sea is a branch of the Indian Ocean and is regarded by oceanographers as an ocean in formation. It has the shape of a large and narrow gulf, extending northsouth and separating the eastern coast of North Africa from the western Arabian Peninsula (Fig. 1). This almost land-locked sea is connected artificially to the north with the Mediterranean, via the Suez Canal, and to the south with the Gulf of Aden (Indian Ocean), via the Bab el Mandeb, a narrow strait just $30 \mathrm{~km}$ wide and only 130 metres deep at the Hanish Sill. Thus, the major currents of these connecting seas fail to enter the Red Sea, exception made for a small inward current at the northern extremity and a more complex bidirectional two- or three-layered current at the Bab el Mandeb (Sheppard et al., 1992). The tidal range changes from north to south, with greatest values at the two ends and decreasing towards the central part of the Red Sea, at about $20^{\circ} \mathrm{N}$, where tides are virtually absent (Sheppard et al., 1992). The Red Sea occupies a large part of the submerged Afro-Syrian Great Rift Valley with long, straight shorelines and narrow coastal plains (Pritchard, 1979) (Fig. 2). It has a maximum width of $355 \mathrm{~km}$, and originated from the gradual separation of the Arabian tectonic plate from Africa, which is still rotating northeastwards with an anticlockwise shift of about $5 \mathrm{~cm} /$ year. The Red Sea is the world's northernmost tropical sea and has the best-developed coral reefs in the western Indian Ocean region. It is home to more than 250 species of hard (scleractinian) corals, which is the highest diversity presently recorded in the Indian Ocean (Pilcher, 2002). 


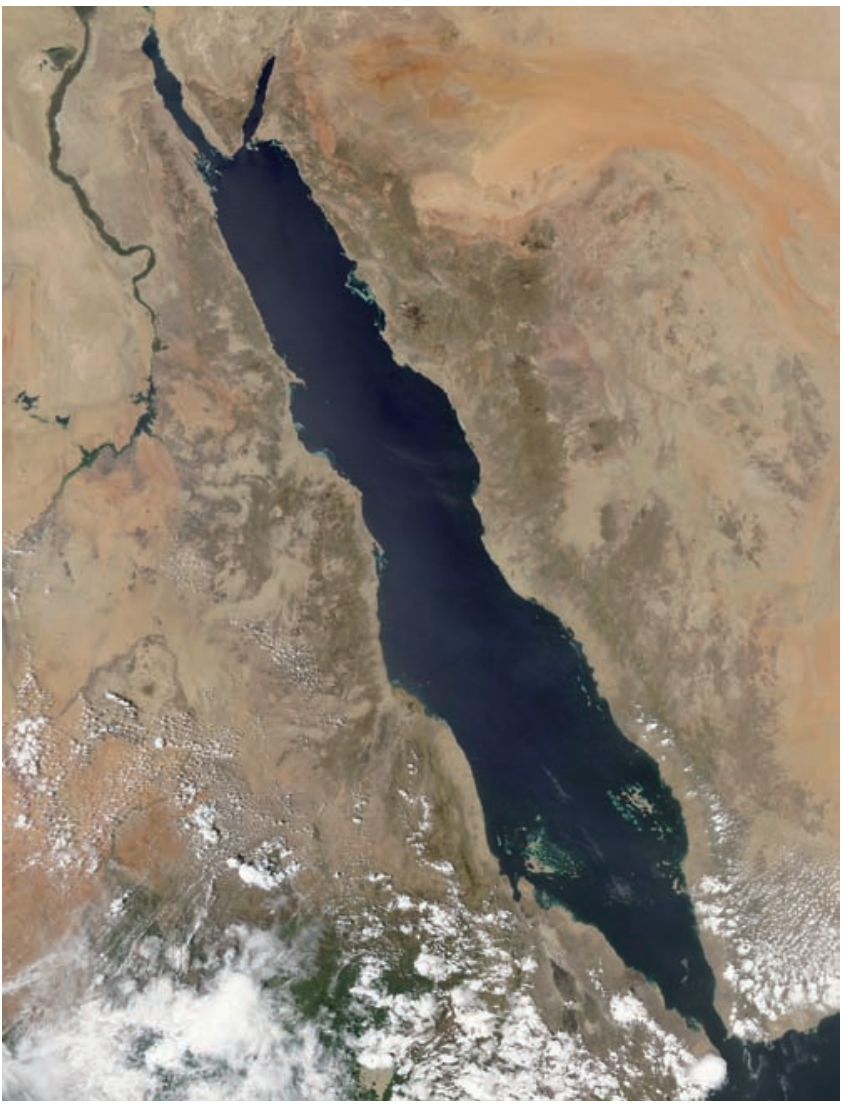

Fig. 1 - The Red Sea, as seen from space (NASA/courtesy of visibleearth.nasa.gov.)
Warm water and the lack of significant fresh water runoff from the Red Sea coasts and islands provide ideal conditions for the formation of the world's least impacted coral reefs (Pilcher, 2002).

Like stars in a clear night sky, the islands of the Red Sea seem countless. Indeed, there are more than 350 islands in the territorial waters of Eritrea alone, and over 100 in those of Yemen. The islands have different geological origins. Some new islands were formed by underwater eruptions (cf. Gass et al., 1973), as in the case of a new lava islet formed in December 2011 in the Zubayr volcanic archipelago of Yemen (Klemetti, 2011). However, only a few are volcanic in origin, such as those of the Zubayr and Hanish archipelagoes and some islands in the Howakil Bay (Eritrea) and in southern Eritrea (Coleman, 1993; De Marchi et al., 2009). Located about $50 \mathrm{~km}$ west of the Red Sea axis, between $23^{\circ}$ and $24^{\circ} \mathrm{N}$, the Egyptian Zabargad is not a volcanic island but probably an uplifted block of upper mantle and crustal rocks (Bonatti et al., 1983; Coleman, 1993). In contrast, other islands are low, flat and sandy, and consist of fossilised coral (cf. Felemban, 1995). Others are of continental origin, for example the Eritrean Dissei, which is close to the Buri Peninsula (De Marchi et al., 2009). Although the majority of the Dahlak (Eritrea) and the Farasan (Saudi Arabia) islands are coral in origin, the fact that they are quite close to mainland coasts make them appear like continental archipelagoes, too.

At the end of Pleistocene, the majority of the Red Sea islands were joined to the nearest African and Arabian mainland (cf. Macfadyen, 1930). In that epoch, the sea level dropped $130 \mathrm{~m}$ below the present level, allowing con-

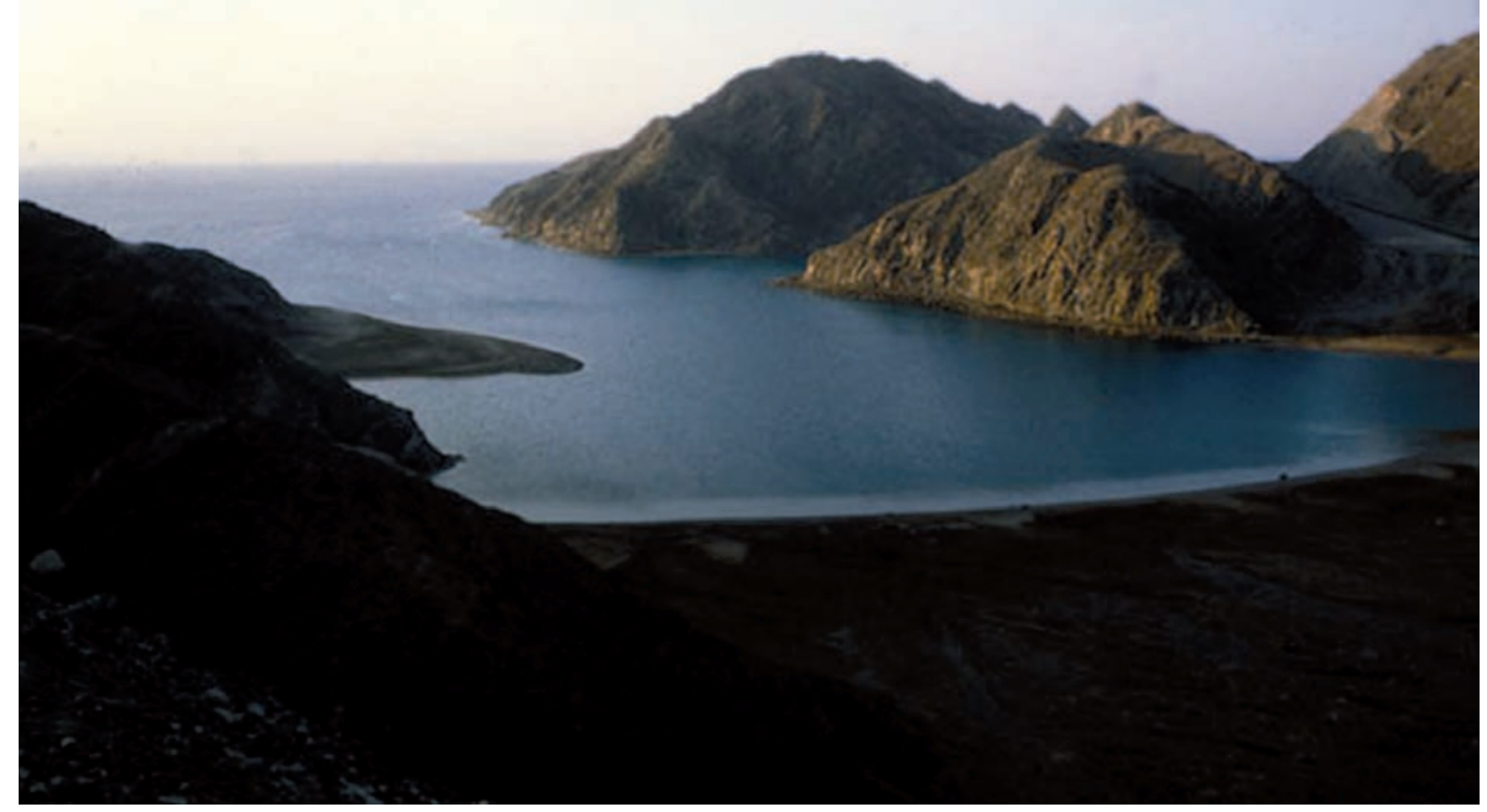

Fig. 2 - Marsá al Marākh, located 9 km south-west of Taba, near the Israeli-Egyptian border, is a small inlet of the northern Red Sea also known as the "fjord" - regarded as the geographical point at which the Afro-Syrian Great Rift Valley enters the Eurasian mainland (photo by Marco Masseti). 
tinental fauna to colonise the islands. The exceptions are a few islands surrounded by deep sea: The Brothers islands, small coral outcrops; the medium-sized Zabargad island, which originated from a tectonical upthrust of upper mantle material; and the Zubayr archipelago, a group of ten islands formed by the top of a shield volcano on the axial zone, at the spreading margin between the African and Arabian plates. Today, the Bab el Mandeb strait is about $30 \mathrm{~km}$ wide, but at the peak of the last glacial it was much narrower. Though the strait was never completely closed, there may have been islands in-between which could have been reached with rudimentary rafts (Bailey et al., 2007). The fact that many of these islands are relatively remote, with no freshwater sources, has largely prevented human settlement; thus, the terrestrial and underwater habitats remain largely undisturbed by human activity, providing a rare opportunity for faunistic and zoogeographical studies. Moreover, the opening of the Suez Canal has connected the Indian Ocean with the Mediterranean Sea since 1869. As the current flows in only one direction - from the Red Sea to the Mediterranean - it has enabled the colonisation of the Mediterranean by a large number of species from the Red Sea (Lessepsian migration), many of which have become invasive (Por, 2009; Pancucci-Papadopoulou et al., 2012). Apparently, very few species have taken the opposite route (Sheppard et al., 1992).

The complete absence of permanent fresh water on many of the Red Sea islands makes them quite difficult to colonise (Fig. 3). Some - i.e., the Egyptian Tiran (Su-
Aretz, 1979) and Zabargad (Gübelin, 1981), or the Seven Brothers islands off Djibouti (Bark Jones, 1946) - can be rightly defined as "desert islands". Many of them are fringed with mangroves (cf. Gladstone, 2000), which are at the world's northernmost limit of their geographical range along the southern Sinai coast (Lipkin, 1987; Pilcher, 2002). Rainfall is higher in the southern Red Sea, although it rarely exceeds $100 \mathrm{~mm} /$ year, allowing a more varied and extensive vegetation cover (Edwards, 1987).

The present study intends to provide a comprehensive review of the mammals living on the Red Sea islands. Knowledge of this subject is scattered over dozens of publications, and no attempt has ever been made before to summarise it, apart from a recent paper on the mammals of the Farasan archipelago (Masseti, 2010a). The present study is based on information in the literature and on direct observations of recent collections.

\section{MATERIALS AND METHODS}

The composition of the non-volant mammalian fauna of the Red Sea was based on the collections of European and North American natural history museums. We particularly focused on those kept in the countries that once colonised the regions bordering the Red Sea or that are known to keep collections of explorers and naturalists that had visited those areas. Today, most of the region is politically unstable and unsafe for scientific researchers to visit.

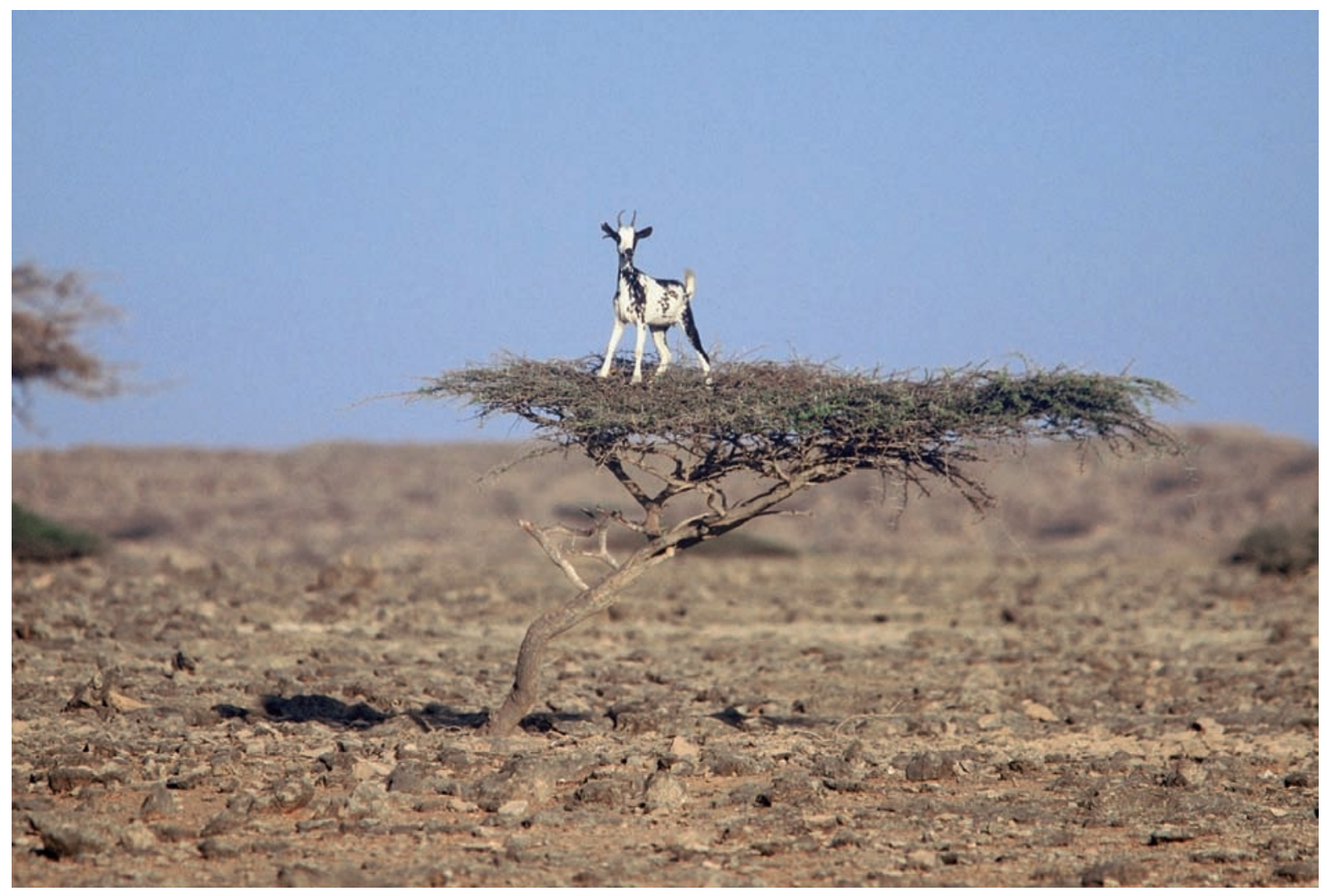

Fig. 3 - Domestic goat of the Galla Somali race climbing an Acacia tree in search of food on the island of Dahlak Kebir (Eritrea). The paucity of food and water on the Red Sea islands makes life hard for mammals (photo by Giuseppe De Marchi). 
Unfortunately, not many mammalian specimens from this area are preserved in natural history museums. Therefore, our information was completed on the basis of the scientific literature and trip reports from the end of the $16^{\text {th }}$ century (see Ramusio, 1563) to the present (Tab. 1). Further additions include a few mammal specimens collected by one of us (GDM) in the Dahlak archipelago, and now kept at the Museo di Storia Naturale di Milano (Italy), as well as field records collected during ornithological expeditions carried out in 2002-2004 by GDM and GC in the southern Eritrean Red Sea.

\section{RESULTS}

During the course of the present study, data on the nonvolant terrestrial mammals of the Red Sea archipelagoes could be obtained from only a few islands (Fig. 4). These included the Egyptian Shadwan; the Sudanese Sawākin and Debir (Er Rih); the Eritrean Massawa, Sheik Said, Dissei, Dahlak archipelago (Dahlak Kebir, Dohul Bahut, Sheik Said, NN086, Sayin, Harat, Dahret, Dur Ghella, Isratu, Entedebir, and Museri) (Fig. 5), and Fatmah; the Saudi Arabian al Hasani and Farasan archipelago (Farasan Al-Kebir, Segid, Zifaf, Dumsuq, and Qummah); and the Yemenite Sumayr and al-Hanish al-Kabir.

Tab. 1 - References dated from 1790 to 2014 reporting the occurrence of non-volant terrestrial mammal species on Red Sea islands and archipelagoes.

\begin{tabular}{|c|c|c|}
\hline Island or archipelago & Country & References \\
\hline Shadwan & Egypt & Osborn \& Helmy, 1980 \\
\hline Sawākin & Sudan & $\begin{array}{l}\text { Heuglin, 1877; Anderson \& De Winton, 1902; Kock, 1980; Evans, } \\
\text { 1987; Shobrak et al., 2003; Gladstone et al., } 2006\end{array}$ \\
\hline Debir (Er Rih) & Sudan & Heuglin, 1861 \\
\hline Massawa & Eritrea & $\begin{array}{l}\text { Cretzschmar, 1830; Rüppell, 1835; Heuglin, 1861; Brehm, 1863; } \\
\text { Heuglin \& Fitzinger, 1866; Heuglin, 1877; Anderson \& De Winton, } \\
\text { 1902; Del Prato, 1891; Sordelli, 1902; Parisi, 1917; De Beaux, 1923; } \\
\text { Mertens, 1925; Largen et al., 1974; Yalden et al., 1976; Kock, } 1980\end{array}$ \\
\hline Sheik Said & Eritrea & Heuglin \& Fitzinger, 1866 \\
\hline Dissei & Eritrea & De Marchi et al., 2006; De Marchi et al.,2009 \\
\hline $\begin{array}{l}\text { Dahlak archipelago (Dahlak } \\
\text { Kebir, Dohul Bahut, Sheik } \\
\text { Said, NN086, Sayin, Harat, } \\
\text { Dahret, Dur Ghella, Isratu, } \\
\text { Entedebir, and Museri) }\end{array}$ & Eritrea & $\begin{array}{l}\text { Bruce of Kinnaird, 1790; Annesley Mountnorris, 1811; Ehrenberg, } \\
\text { 1827; Rüppell, 1838 and 1840; Heuglin, 1861 and 1877; Heuglin } \\
\text { \& Fitzinger, 1866; Del Prato, 1891; Sclater \& Thomas, 1897-1898; } \\
\text { Sordelli, 1902; Parisi, 1917; De Beaux, 1923; Baschieri, 1954; } \\
\text { Baschieri Salvadori, 1954; Roghi \& Baschieri, 1954; Clapham, 1964; } \\
\text { Lewinsohn \& Fishelson, 1967; Largen et al., 1974; Harrison, 1965 } \\
\text { and 1972; Hayman \& Hill, 1971; Bolton, 1973; Yalden et al., 1976; } \\
\text { Kock, 1980; Kingdon, 1982; Yalden et al., 1984; Hillman, 1993; } \\
\text { Yalden et al., 1996; De Marchi, 2002; Oriani \& Castiglioni, 2003; } \\
\text { Shobrak et al., 2003; Benardelli, 2004; De Marchi, 2004; Grubb, } \\
\text { 2005; Torunsky et al., 2007; De Marchi et al., 2009; Anderson et al. } \\
\text { 2013; Gippoliti, } 2010 \text { and 2013; Chiozzi et al., 2014a }\end{array}$ \\
\hline Fatmah & Eritrea & De Beaux, 1930-31 \\
\hline $\begin{array}{l}\text { al Hasani island and the Farasan } \\
\text { archipelago (Farasan Al-Kebir, } \\
\text { Segid, Zifaf, Dumsuq, and } \\
\text { Qummah) }\end{array}$ & Saudi Arabia & $\begin{array}{l}\text { Dollman, 1927; Harrison, 1968; Kingdon, 1982; Groves, 1983, 1985; } \\
\text { Flamand et al., 1988; Jennings, 1988; Grubb, 2005; Kingdon, 1990; } \\
\text { Harrison \& Bates, 1991; Thouless, 1991; Thouless \& Al Bassri, } \\
\text { 1991; Evans, 1994; Newton, 1995; Gladstone, 2000; NCWCD, 2000; } \\
\text { Fisher 2001; Mallon and Kingswood 2001; Mallon \& Hoffmann, } \\
\text { 2008; Grubb, 2005; Torunsky et al., 2007; Masseti \& Bruner, 2009; } \\
\text { Masseti, 2010a; Torunsky et al., 2010; Bärmann et al., 2013; Lerp et } \\
\text { al.,2013; Wronski, } 2013\end{array}$ \\
\hline Sumayr (Zimmer) & Yemen & Bruce of Kinnaird, 1790 \\
\hline al-Hanish al-Kabir & Yemen & $\begin{array}{l}\text { Dollman, 1927; Haltenorth \& Diller, 1977; Nader, 1990; Harrison \& } \\
\text { Bates, 1991; Al-Jumaily, } 1998\end{array}$ \\
\hline
\end{tabular}


The species collected during recent surveys are the following:

1) A shrew of the genus Crocidura Wagler, 1832, characterised by a very flat braincase: one partial skull (Fig. 6) collected among food remains found in a small cave inhabited by a barn owl, Tyto alba (Scopoli, 1769), on Isratu Island, Dahlak archipelago, in November 1999. Although this specimen is not very well preserved, we estimated a condylobasal length of $16.5 \mathrm{~mm}$ and a zygomatic breadth of $7.8 \mathrm{~mm}$. The presence of 8 teeth in the upper dentition and the absence of the fourth small upper unicuspid suggest a representative of the genus Crocidura rather than Suncus. Based on our preliminary morphological analy- sis, the specimen could not be identified at the species level.

2) Northeast African spiny mouse, Acomys (Acomys) cahirinus (É. Geoffroy, 1803): several specimens trapped on 21 February 2010 and 7 March 2010 on Dur Ghella island (Dahlak archipelago).

3) House mouse, Mus (Mus) musculus L., 1758: a single specimen found dead on Dahret Island, Dahlak archipelago, on 8 July 2008.

The complete non-volant terrestrial mammal list recorded so far on the Red Sea islands (including the abovementioned species) is given in Tab. 2 .
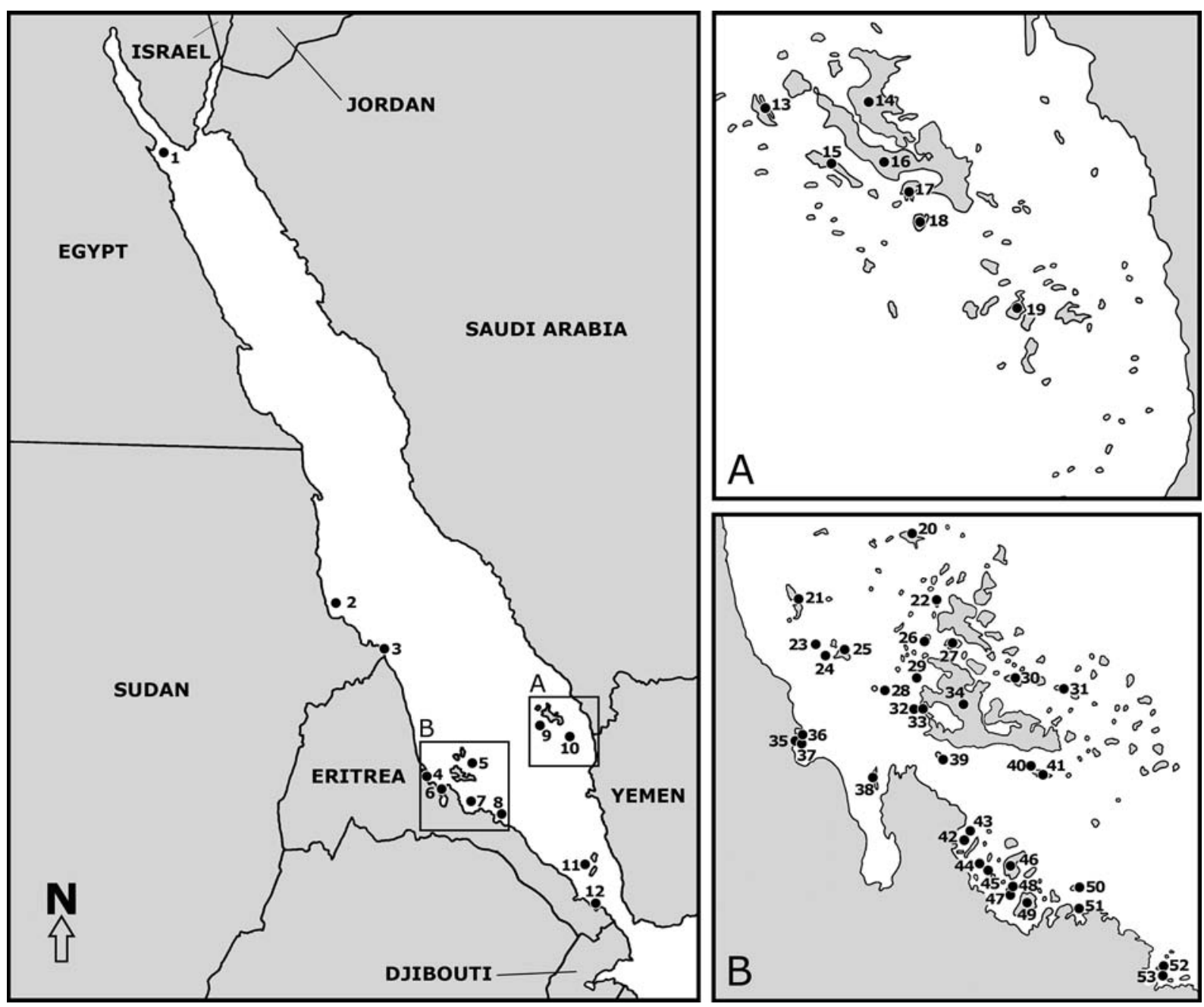

Fig. 4 - Location of the Red Sea areas and islands with reports of the presence of non-volant mammals (see Tab. 2 for recorded species and Appendix for geographical information). The map to the right shows the Red Sea in the context of its bordering countries. Maps A and B (left side) are enlargements of corresponding areas on the main map. The maps are not drawn to the same scale.

Red Sea island areas (numbers 1 to 12): 1=Shadwan island; 2=Sawākin island; 3=Debir island; 4=Massawa (Massawa, Taulud and Sheik Said islands); $5=$ Dahlak archipelago; $6=$ Dissei island; $7=$ Howakil bay; $8=$ Anfile bay; $9=$ Farasan archipelago; $10=$ Sumayr island; 11=Hanish archipelago (al-Hanish al-Kabir island); 12=Assab bay (Fatmah island).

Map A: Saudi and Yemeni islands (numbers 13 to 19): 13=Sarso; 14=Segid; 15=Zifaf; 16=Farasan Al-Kebir; 17=Qummah; 18=Dumsuq; $19=$ Sumayr.

Map B: Eritrean islands (numbers 20 to 53): 20= Isratu; 21= Harat; 22=Kad Norah; 23=Dohul Bahut; 24=Dahret; 25=Dohul; 26=Dar Solum; 27=Dhu-ladhyia; 28=Dur Ghella; 29=Sarad; 30=Sayin; 31=Gharib; 32=Entedebir; 33=Nocra; 34=Dahlak Kebir; 35=Taulud; 36=Massawa; 37=Sheik Said; 38=Dissei; 39=Shumma; 40=NN086; 41=Museri; 42=Dasetto; 43=Dase; 44=Dahaila Kebir; 45=Dahaila Seghir; 46=Howakil; 47=Umm es Seil; 48=Debel Ali; 49=Baka; 50=Umm es Sahrig; 51=NN045; 52=Handa; $53=$ Hant. 


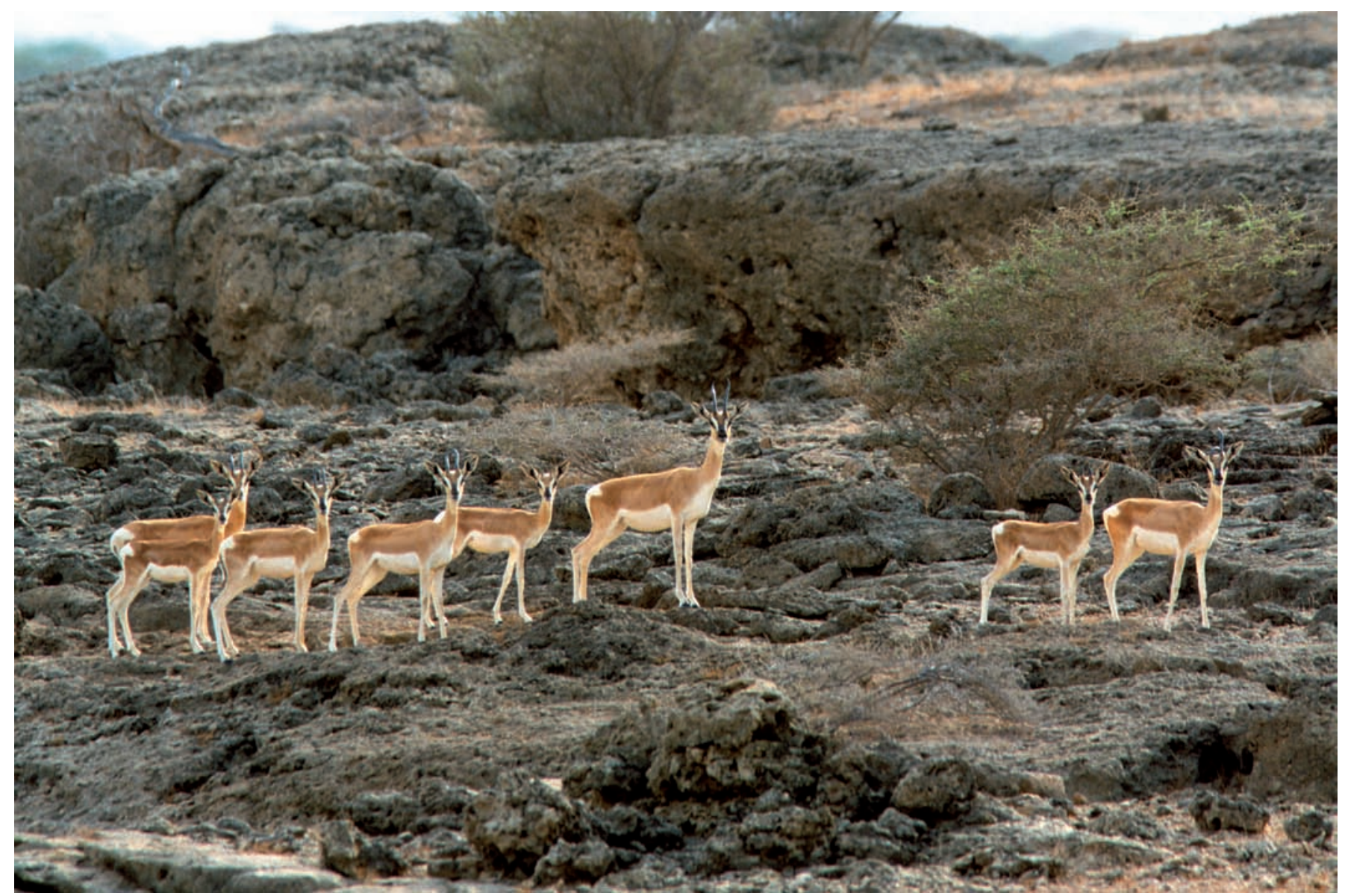

Fig. 5 - A population of Soemmerring's gazelle, Nanger soemmerringii (Cretzschmar, 1828), on the island of Dahlak Kebir (photo by Giuseppe De Marchi).

Tab. 2 - List of all known non-volant mammals of the Red Sea islands.

* ZMB 2115 (skull and skin, labelled "Type" of Gazella arabica Hemprich and Ehrenberg);

**BMNH 97.12.21.1, 14 April 1897 3 . Original label: Gazella littoralis partial skull with horns (trophy) + skin coll. Capt. C. Fleming.); ${ }^{2}$ MSNG 1458 (o ad.) and 1463 (ô iuv.) Gazella isabella isabella. It may be interesting to note that several authors have argued that Dahlak Kebir island was formerly inhabited by gazelles of a species different from that now present: Gazella gazella according to Ehrenberg (1827), or Gazella isabella Gray, 1846, according to Baschieri (1954) and Baschieri Salvadori (1954). G. isabella is a synonym of $G$. dorcas (Grubb, 2005), formerly also indicated at the subspecific level as G. dorcas isabella (Groves, 1997). According to Sclater \& Thomas (1898), the habitat of Gazella isabella isabella extended along the Red Sea coast from Sawākin southwards to Massawa and territories inland up to Bogos, Barka and the region of Taka (De Beaux, 1930-31).

$(\dagger=$ extinct; $\mathrm{BMNH}=$ British Museum Natural History; $\mathrm{MSNG}=$ Museo Civico di Storia Naturale di Genova; MSNM = Museo di Storia Naturale di Milano; MZUF = Museo di Zoologia dell'Università di Firenze; SFM $=$ Senckenberg Museum Frankfurt; ZMB $=$ Zoologischen Museum in Berlin). Systematic treatment and common names after Wilson \& Reeder (2005).

\begin{tabular}{|l|l|l|l|l|}
\hline$\#$ & Common name & Scientific name & Islands & References and museum specimens \\
\hline 1 & $\begin{array}{l}\text { Ethiopian } \\
\text { hedgehog }\end{array}$ & $\begin{array}{l}\text { Paraechinus aethiopicus } \\
\text { Ehrenberg, 1832 }\end{array}$ & Massawa & Leche, 1902; Laurent \& Laurent, 2002 \\
\hline 2 & $\begin{array}{l}\text { Undetermined } \\
\text { shrew }\end{array}$ & Crocidura sp. & Isratu & present work; MSNM Ma7901 \\
\hline 3 & $\begin{array}{l}\text { Sahelian tiny } \\
\text { shrew }\end{array}$ & $\begin{array}{l}\text { Crocidura pasha } \\
\text { Dollman, 1915 }\end{array}$ & Sawākin & Kock, 1980 \\
\hline
\end{tabular}




\begin{tabular}{|c|c|c|c|c|}
\hline \# & Common name & Scientific name & Islands & References and museum specimens \\
\hline 4 & Asian house shrew & $\begin{array}{l}\text { Suncus murinus (L., } \\
1766)\end{array}$ & $\begin{array}{l}\text { Dahlak Isls'; } \\
\text { Sawākin'; } \text { Dahlak } \\
\text { Kebir }^{3,4,5,7} \text {; } \\
\text { Massawa }^{1,2,3,4,5,6,7}\end{array}$ & $\begin{array}{l}{ }^{1} \text { Heuglin, } 1861 ;{ }^{2} \text { Heuglin, } 1877 ; \\
{ }^{2} \text { Anderson \& De Winton, 1902; }{ }^{3} \mathrm{Del} \\
\text { Prato, 1891; }{ }^{3} \text { Sordelli, 1902; }{ }^{3} \text { Parisi, } \\
\text { 1917; }{ }^{4} \text { Yalden et al., 1976; }{ }^{5} \text { Kock, } 1980 \text {; } \\
{ }^{6} \text { SFM 1334, 12516; }{ }^{7} \text { Rüppell, } 1840\end{array}$ \\
\hline 5 & Hamadryas baboon & $\begin{array}{l}\text { Papio hamadryas (L., } \\
\text { 1758) }\end{array}$ & $\begin{array}{l}\text { Massawa }^{1} \text {; Farasan } \\
\text { Al-Kebir }\end{array}$ & $\begin{array}{l}{ }^{1} \text { Rüppell, 1835; }{ }^{1} \text { Yalden et al., 1977; } \\
{ }^{2} \text { MZUF 11329; }{ }^{2} \text { Masseti \& Bruner, } \\
\text { 2009; }{ }^{2} \text { Masseti, 2010a }\end{array}$ \\
\hline 6 & Caracal & $\begin{array}{l}\text { Caracal caracal } \\
\text { (Schreber, 1776) }\end{array}$ & Sawākin & Setzer, 1956 \\
\hline 7 & Wildcat & $\begin{array}{l}\text { Felis silvestris Schreber, } \\
1777\end{array}$ & Sawākin & Setzer, 1956 \\
\hline 8 & Pale fox & $\begin{array}{l}\text { Vulpes pallida } \\
\text { (Cretzschmar, 1826) }\end{array}$ & Sawākin & Setzer, 1956 \\
\hline 9 & ? Rüppell's fox? & $\begin{array}{l}\text { ? Vulpes rueppellii } \\
\text { (Schinz, 1825)? }\end{array}$ & $\begin{array}{l}\text { Massawa }^{1} \text {; Debir } \\
(\text { Er Rih })^{2}\end{array}$ & $\begin{array}{l}{ }^{1} \text { Heuglin, } 1877 ;{ }^{1} \text { De Beaux, 1928, } \\
\text { 1930-1931; Heuglin, 1861; Heuglin \& } \\
\text { Fitzinger, } 1866\end{array}$ \\
\hline 10 & $\begin{array}{l}\text { White-tailed } \\
\text { Mongoose }\end{array}$ & $\begin{array}{l}\text { Ichneumia albicauda } \\
\text { (G. [Baron] Cuvier, } \\
\text { 1829) }\end{array}$ & $\begin{array}{l}\text { Farasan Al-Kebir }{ }^{1} \text {; } \\
\text { Dissei }^{2}\end{array}$ & $\begin{array}{l}{ }^{1} \text { Jennings, } 1988 ;{ }^{1} \mathrm{NCWCD}, 2000 ; \\
{ }^{1} \text { Fisher, 2001; }{ }^{1} \text { Masseti, } 2010 \mathrm{a} ;{ }^{2} \text { De } \\
\text { Marchi et al., 2006; }{ }^{2} \text { De Marchi et al., } \\
2009\end{array}$ \\
\hline 11 & Striped hyaena & $\begin{array}{l}\text { Hyaena hyaena }(\mathrm{L} . \\
1758)\end{array}$ & Sumayr & $\begin{array}{l}\text { Bruce of Kinnaird, 1790; cf. } \\
\text { Tuchscherer, } 2004\end{array}$ \\
\hline 12 & Aardwolf & $\begin{array}{l}\text { Proteles cristata } \\
\text { (Sparrman, 1783) }\end{array}$ & Sawākin & Setzer, 1956 \\
\hline 13 & Honey badger & $\begin{array}{l}\text { Mellivora capensis } \\
\text { (Schreber, 1776) }\end{array}$ & Sawākin & Setzer, 1956 \\
\hline 14 & $\begin{array}{l}\text { Arabian (Farasan) } \\
\text { gazelle }\end{array}$ & $\begin{array}{l}\text { Gazella arabica } \\
\text { (Lichtenstein, 1827)* }\end{array}$ & $\dagger$ Farasan Al-Kebir & $\begin{array}{l}\text { ZMB 2115; Dollman, 1927; Groves, } \\
\text { 1983, 1985; Nader, 1990; Grubb, } 2005\end{array}$ \\
\hline 15 & Dorcas gazelle & $\begin{array}{l}\text { Gazella dorcas (L., } \\
1758)\end{array}$ & $\begin{array}{l}\text { Sawākin } \\
\text { Massawa }^{2}\end{array}$ & $\begin{array}{l}{ }^{1} \text { BMNH } 97.12 .21 .1 * * ;{ }^{1} \text { Lydekker, } 1914 \text {; } \\
{ }^{1} \text { Setzer, 1956; }{ }^{2} \text { MSNG } 1458 \text { and } 1463\end{array}$ \\
\hline 16 & Mountain gazelle & $\begin{array}{l}\text { Gazella gazella (Pallas, } \\
1766 \text { ) }\end{array}$ & $\begin{array}{l}\text { Segid }{ }^{1,2,3,5}, \text { Farasan } \\
\text { Al-Kebir }^{1,2,3,4,5} \\
{ }^{8}, \text { Zifaf }^{1,2,3,5} \\
\text { Dumsuq }^{1,2,3,5} \text {, and } \\
\text { Qummah } \\
\text { Q,2,3,5, al- } \\
\text { Hanish al-Kabir } \\
\text { Sumayr }\end{array}$ & $\begin{array}{l}{ }^{1} \text { Kingdon, } 1990 ;{ }^{2} \text { Thouless \& Al Bassri, } \\
\text { 1991; }{ }^{3} \text { Masseti, } 2010 \mathrm{a} ;{ }^{4} \mathrm{MZUF} 11330 \text {, } \\
\text { 11331, 11332; }{ }^{5} \text { Cunningham \& Wronski, } \\
\text { 2011; }{ }^{6} \text { Dollman, } 1927 ;{ }^{6} \text { Haltenorth \& } \\
\text { Diller, 1977; }{ }^{6} \text { Nader, } 1990 ;{ }^{6} \text { Harrison \& } \\
\text { Bates, 1991; }{ }^{6} \text { Al-Jumaily, } 1998 ;{ }^{7} \text { Bruce } \\
\text { of Kinnaird, } 1790 ;{ }^{8} \text { Flamand } \text { et al., } 1988 ;\end{array}$ \\
\hline 17 & $\begin{array}{l}\text { Soemmerring's } \\
\text { gazelle }\end{array}$ & $\begin{array}{l}\text { Nanger soemmerringii } \\
\text { (Cretzschmar, 1828) }\end{array}$ & $\begin{array}{l}\text { Sawākin'1; Dahlak } \\
\text { Kebir }^{2}\end{array}$ & $\begin{array}{l}{ }^{1} \text { Lydekker, 1914; }{ }^{1} \text { Haltenorth \& Diller, } \\
1977 ;{ }^{2} \text { Bruce of Kinnaird, 1790; } \\
{ }^{2} \text { Annesley Mountnorris, 1811; }{ }^{2} \text { Rüppell } \\
\text { 1838; }{ }^{2} \text { Heuglin, 1861; }{ }^{2} \text { Bolton, 1973; } \\
\text { Kingdon, 1982; }{ }^{2} \text { Yalden et al., 1984; } \\
{ }^{2} \text { Hillman, 1993; }{ }^{2} \text { Yalden et al., 1996; } \\
{ }^{2} \text { De Marchi, 2004; }{ }^{2} \text { BMNH 69.783, ZD } \\
\text { 1993.56- ZD 1993.59; }{ }^{2} \text { MSNM Ma7634- } \\
\text { Ma7663 }\end{array}$ \\
\hline 18 & $\begin{array}{l}\text { Lesser Egyptian } \\
\text { gerbil }\end{array}$ & $\begin{array}{l}\text { Gerbillus (Gerbillus) } \\
\text { gerbillus (Olivier, 1801) }\end{array}$ & Massawa & Laurent \& Laurent, 2002 \\
\hline
\end{tabular}




\begin{tabular}{|c|c|c|c|c|}
\hline \# & Common name & Scientific name & Islands & References and museum specimens \\
\hline 19 & Brown rat & $\begin{array}{l}\text { Rattus norvegicus } \\
\text { (Berkenhout, 1769) }\end{array}$ & $\begin{array}{l}\text { Massawa }^{1} ; \\
\text { Fatmah }^{2} \text {, Assab } \\
\text { bay isls (Eritrea) }\end{array}$ & $\begin{array}{l}{ }^{1} \text { Rüppell, 1842; }{ }^{1} \text { Laurent \& Laurent, } \\
\text { 2002; }{ }^{2} \text { De Beaux, 1930-1931; }{ }^{2} \text { Laurent } \\
\text { \& Laurent, } 2002\end{array}$ \\
\hline 20 & Black rat & Rattus rattus (L., 1758) & 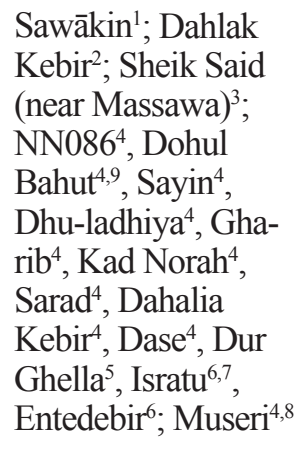 & $\begin{array}{l}{ }^{1} \text { Evans, 1987; }{ }^{1} \text { Shobrak et al., } 2003 ; \\
{ }^{1} \text { Gladstone } \text { et al., 2006; }{ }^{2} \text { Rüppell, } 1838 ; \\
{ }^{2} \text { Harrison, 1972; }{ }^{2} \text { Yalden et al., 1976; } \\
\text { Heuglin, 1861; }{ }^{3} \text { Heuglin \& Fitzinger, } \\
\text { 1866; }{ }^{3} \text { present work (De Marchi, January } \\
\text { 2010); }{ }^{4} \text { De Marchi et al., 2006; }{ }^{5} \text { Heuglin } \\
\text { \& Fitzinger, 1866; }{ }^{6} \text { Clapham, 1964; } \\
7 \text { present work (De Marchi, December } \\
\text { 2009); }{ }^{8} \text { The Second Israel South Red Sea } \\
\text { Expedition to the Dahlak Archipelago, } \\
\text { 1965; }{ }^{9} \text { Anderson } \text { et al., } 2013\end{array}$ \\
\hline 21 & House mouse & $\begin{array}{l}\text { Mus (Mus) musculus L., } \\
1758\end{array}$ & $\begin{array}{l}\text { Shadwan island }{ }^{1} \text {; } \\
\text { Sawākin'²; } \\
\text { Massawa }^{2,3}, \\
\text { Dahlak Kebir }{ }^{3}, \text { Dur } \\
\text { Ghella }^{3}, \text { Dahret }^{4}\end{array}$ & $\begin{array}{l}{ }^{1} \text { Osborn \& Helmy, } 1980 ;{ }^{2} \text { Anderson \& } \\
\text { de Winton }(1902) ; \text { Cretzschmar, } 1830 ; \\
\text { 'Heuglin, 1861; }{ }^{3} \text { Brehm, } 1863 ;{ }^{3} \text { Heuglin } \\
\text { \& Fitzinger, 1866; }{ }^{3} \text { Mertens, } 1925 ; \\
{ }^{3} \text { Laurent \& Laurent, 2002; }{ }^{4} \text { Baschieri, } \\
\text { 1954; }{ }^{4} \text { Baschieri Salvadori, } 1954\end{array}$ \\
\hline 22 & $\begin{array}{l}\text { Northeast African } \\
\text { spiny mouse }\end{array}$ & $\begin{array}{l}\text { Acomys (Acomys) cahiri- } \\
\text { nus (E. Geoffroy, 1803) }\end{array}$ & Dur Ghella & De Marchi et al., 2013; present work \\
\hline 23 & $\begin{array}{l}\text { Eastern spiny } \\
\text { mouse }\end{array}$ & $\begin{array}{l}\text { Acomys (Acomys) dimidia- } \\
\text { tus (Cretzschmar, 1826) }\end{array}$ & Farasan Al-Kebir & Masseti, 2010a \\
\hline
\end{tabular}

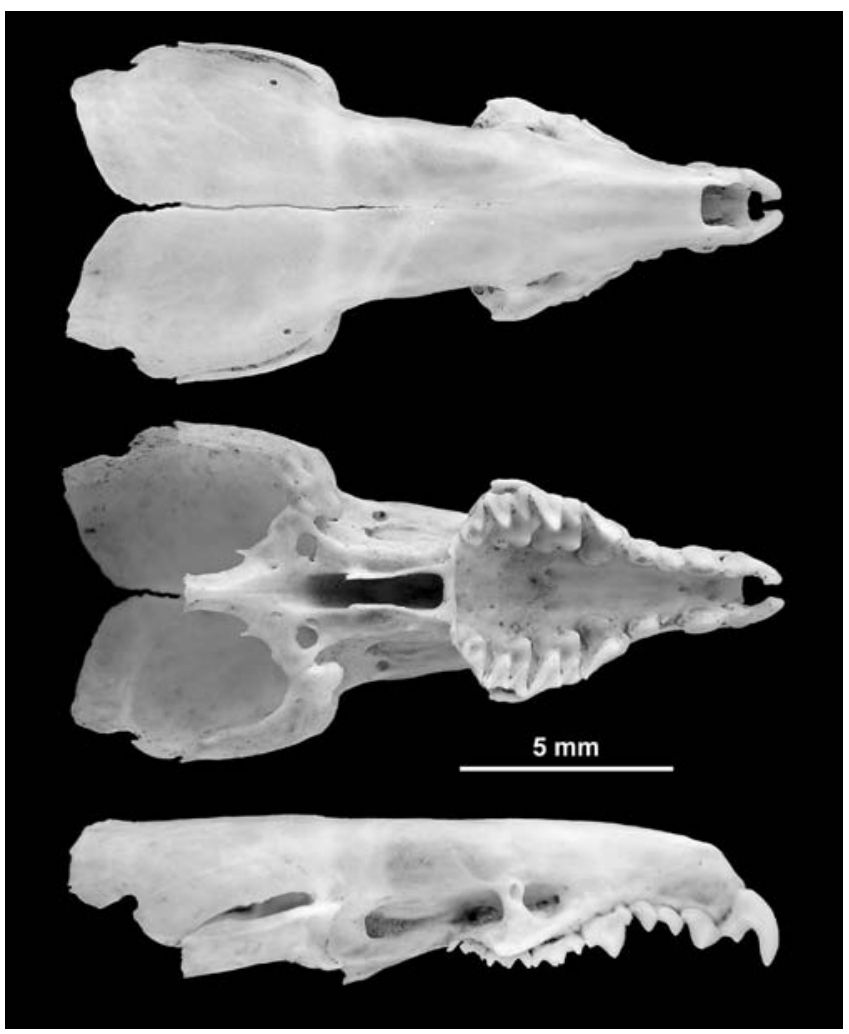

Fig. 6 - The skull of a small soricid (Crocidura sp.), characterised by a flat braincase, found in a pellet from a barn owl, Tyto alba (Scopoli, 1769), in a cave on Isratu island, Dahlak archipelago, in 2009 (photo by Michele Zilioli; Museo di Storia Naturale di Milano).

\section{DISCUSSION}

\section{The extant fauna}

Whereas several islands located very close to the mainland coast feature the occurrence of species such as the brown rat, Rattus norvegicus (Berkenhout, 1769), and the Asian house shrew, Suncus murinus (L., 1766), unexpected additional species have been reported in Sawākin (Sudan) and Massawa (Eritrea). On Massawa, the dorcas gazelle, Gazella dorcas (L., 1758), and the hamadryas baboon, Papio hamadryas (L., 1758), have been reported (Tab. 2). The aardwolf, Proteles cristata (Sparrman, 1783), the caracal, Caracal caracal (Schreber, 1776), the wildcat, Felis silvestris Schreber, 1777, the honey badger, Mellivora capensis (Schreber, 1776), the pale fox, Vulpes pallida (Cretzschmar, 1826), as well as Soemmerring's gazelle, Nanger soemmerringii (Cretzschmar, 1828), have been reported from Sawākin (Setzer, 1956). The subspecies Proteles cristatus pallidior (Cabrera, 1910) was described based on one specimen from Sawākin (Cabrera, 1910). However, both towns are connected to the coast by "artificial land bridges". Sawākin, a round island at the end of a long inlet, is linked to the mainland by a causeway $(90 \mathrm{~m})$ built in 1877 . Mammals likely reached Massawa islands (Taulud and Massawa) by walking along the causeways that link the mainland to Taulud $(1030 \mathrm{~m})$, and Taulud to Massawa $(200 \mathrm{~m})$, both built in the 1870s. Even more likely, the findings were inaccurately geolocalised, being referred to the nearby mainland rather than to Massawa and Sawākin islands. It appears rather unlikely that 
these species settled on such densely inhabited islands. As for other mammals that are officially said to have been collected from Sawākin, we are more inclined to believe that they had been brought to Henry W. Setzer from the mainland during his stay on the Sudanese island.

The hamadryas baboon was recorded for the first time on the Red Sea island of Massawa by Rüppell (1835). However, Rüppell's text 'Ungemein häufig in ganz Abyssinien, von der Meeresküste bei Massaua bis zu ...' [= 'Very frequent throughout Abyssinia, by the seashore at Massawa up to...'] is unclear about the location of the finding and might well refer to the mainland of Massawa rather than to the island itself. Many decades later, in April 1984, a complete skull with mandible of a subadult female was discovered in a temporary burial on Farasan Al-Kebir, and since then has been kept in the collections of the Zoological Section "La Specola" of the Museum of Natural History of the University of Florence, under the catalogue number MZUF 11329 (Masseti \& Bruner, 2009; Masseti, 2010a) (Fig. 7). This species is not to be regarded a true Red Sea island mammal, since it has been recorded only twice based on remains of single specimens (Masseti, 2010a). They were most likely pets, introduced by humans to Farasan Al-Kebir (Masseti \& Bruner, 2009) and Massawa: indeed, live baboons are regularly kept as pets by Eritreans, mainly children. Moreover, hamadryas are often commensals with humans in their Saudi Arabian and East African continental ranges (Lackman-Acrenaz, 1998).

Worth noting is the almost complete absence of records of Erinaceidae. So far, only one species, the desert hedgehog, Paraechinus aethiopicus Ehrenberg, 1832, has been reported from Massawa (Leche, 1902; Laurent \& Laurent, 2002): it might have arrived at the island via the causeways or might have been actually observed on the mainland, as has occurred for other species. In contrast, erina-

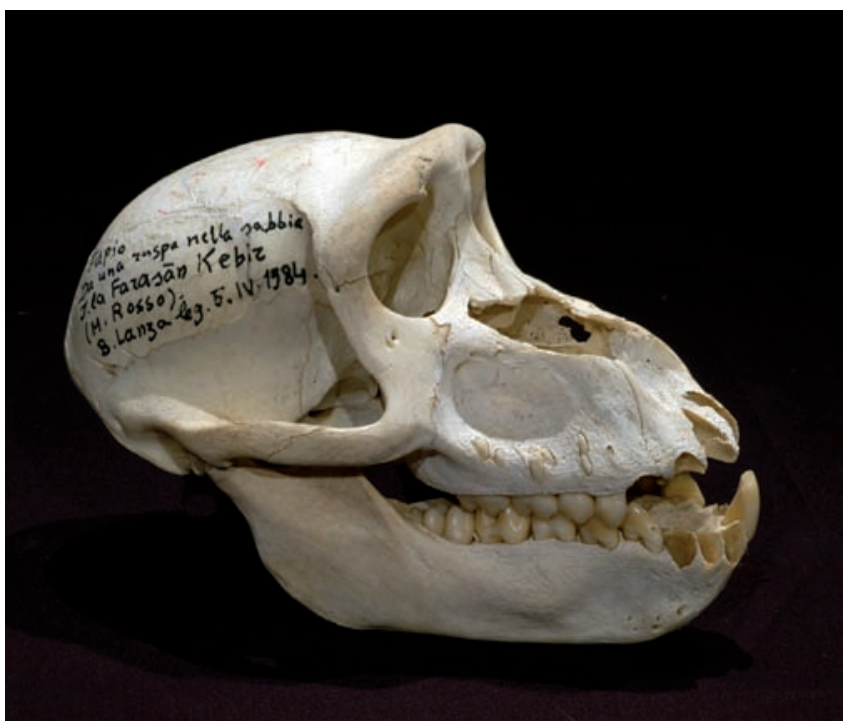

Fig. 7 - Skull of a subadult female of Arabian hamadryas baboon, Papio hamadryas arabicus Thomas, 1900, found on the island of Farasan Kebir in April 1984 (photo by Saulo Bambi; courtesy of the Museo di Storia Naturale dell'Universita di Firenze, Sezione di Zoologia "La Specola"). ceids are widespread on the islands of the Persian Gulf: the long-eared hedgehog, Hemiechinus auritus (Gmelin, 1770), is reported on Bahrein (Hill \& Webb, 1984), together with the desert hedgehog (Harrison, 1972), which has also been recorded from Tanb island (Harrison, 1981; Nader, 1990).

\section{Carnivores}

The carnivore record includes three species: the whitetailed mongoose, Ichneumia albicauda (G. [Baron] $\mathrm{Cu}-$ vier, 1829), a not better-identified fox, and possibly the striped hyena, Hyaena hyaena (L., 1758). The occurrence of the hyena was noted by Bruce of Kinnaird (1790) on the island of Zimmer (Jazirat Sumayr), which is located south of the Farasan archipelago, but already in Yemenite territorial waters: 'Although Zimmer is said to be without water, yet there are antelopes upon it, as also hyaenas in number, and it is therefore probable that there is water in some subterraneous caves or clefts of the rocks, unknown to the Arabs or fishermen, without which these animals could not subsist. It is probable the antelopes were brought over from Arabia for the Sherriffe's pleasure, or those of his friends, if they did not swim from the main, and an enemy afterwards brought the hyaena to disappoint that amusement. Be that as it will, though I did not myself see the animals, yet I observed the dung of each of them upon the sand, and in the cisterns; so the fact does not rest wholly upon the veracity of the boatman' (Bruce of Kinnaird, 1790: I, p. 351). Tuchscherer (2004) also mentioned these carnivores on the Red Sea islands: 'La faune sauvage, gazelles et hyènes surtout, est assez limitée' [= 'Wild fauna, gazelles and hyenas above all, is fairly limited'].

According to the National Commission for Wildlife Conservation and Development (2000), on the Farasan islands 'Foxes [unspecified at the species level] used to occur but no longer do so [...]. Feral cats and rats competing for the same food may be driving them back'. Indeed, a variety of fox has been reported by Heuglin (1861, 1877), and Heuglin \& Fitzinger (1866), from the island of Debir, which is located off the Sudanese coast, south of Sawākin. On that island, formerly also known as Eiro, are the ruins of the Ptolemaic city of Epitheras, or Theros, cited in the Periplus of the Erythraean Sea (Periplus Maris Erythraei), which dates to 70 A.D. (cf. Schoff, 1912; Casson, 1989). Heuglin (1861) referred the Debir fox to the taxon Canis niloticus (É. Geoffroy Saint Hilaire, 1803). The scientific name of this canid, reminiscent of a jackal, is actually an old synonym for Vulpes vulpes aegyptia$c a$ (Sonnini, 1816), the Egyptian red fox or Nile red fox, which is distributed in the Sinai peninsula, Egypt, as well as to the western Mediterranean coastal desert (Waterhouse, 1838; Osborn \& Helmy, 1980). Since Heuglin (1861) noted that the fox species he reported from Debir was also present in Arabia, this would effectively rule out the above-mentioned $V$. vulpes aegyptiaca, but also the pale fox, Vulpes pallida (Cretzschmar, 1826), which are both unknown in the Arabian Peninsula. The distribution of the red fox does not extend to sub-Saharan Africa: it is actually limited to the north of this continent and the Arabian Peninsula, as well as the remaining Palaearctic region (cf. Wozencraft, 2005). V. pallida, on the other hand, is 
dispersed in the semi-arid Sahelian region of Africa bordering the Sahara, from Mauritania and Senegal through Nigeria, Cameroon and Chad to the Red Sea (Sillero-Zubiri, 2004). Hence Heuglin (1861) likely reported another species, perhaps Rüppell's fox, Vulpes rueppelli (Schinz, 1825), whose range encompasses a large part of the Saharo-Sindian deserts, as well as semi-desert areas, from western North Africa to Saudi Arabia and the Middle East, including Afghanistan and Pakistan (Corbet, 1978; Gasperetti et al., 1985; Mendelssohn \& Yom-Tov, 1999; cf. Wozencraft, 2005). In Africa, this carnivore is found from the northern deserts down south to Sudan and Somalia. The confusion between the different taxa may have stemmed from the fact that, as observed by Cuzin \& Lenain (2004), following Osborne (1992), Rüppell's fox '... may be confused with the red fox [...] which has dark markings to the back of the ears, especially by European observers who may be unfamiliar with the sleekness, pallor and long ears of local red foxes'. Sillero-Zubiri (2004: p. 202) observes that the taxon Canis pallidus Cretzschmar, 1827, has indeed been used to indicate the Rüppell's fox, quoting Rüppell's Atlas zu der Reise im nördlichen Afrika (Rüppell, 1826: p. 34, pl 11), in which the type locality was referred to as "Kordofan", Sudan (see also Merriam, 1898). Thomas (1918) associated V. pallida with Rüppell's fox and also with the fennec fox, Vulpes zerda (Zimmermann, 1780). Also Clutton-Brock et al. (1976) support this grouping, suggesting that these desert foxes are closely related to the Indian fox, $V$. bengalensis (Shaw, 1800), and to the Cape fox, V. chama (A. Smith, 1833). In any case, it would appear that Heuglin (1861) was well aware of the difference between his "Canis niloticus" and the African Vulpes pallida. In his Reise in NordostAfrika, Heuglin (1877) refers to this fox, which he found amidst Avicennia bushes along the coast and on some of the islands of the Red Sea; he tried to compare it with a small, sand-coloured jackal with long legs and ears, described by Blanford (1870) as Canis pallidus Ruepp. The identification of Heuglin's Canis niloticus with another representative of the Canidae family, namely Blanford's fox, Vulpes cana Blanford, 1877, appears more unlikely. This species inhabits the cliffs of the Near Eastern deserts, where it is recorded from the Iranian plateau to the Levant and the southern Arabian Peninsula (Ilani, 1983; Ginsberg \& Macdonald, 1990; Harrison \& Bates, 1991; Abu Baker et al., 2004; Shalmon, 2004; Masseti, 2009b). Peters \& Rödel (1994) first recorded this fox from the western Red Sea shore of Egypt, expanding the canid's known distributional range even into Africa. However, it seems that neither Canis niloticus nor $C$. pallidus have ever been used as synonyms of Vulpes cana. The canid observed on Debir island by Heuglin (1861) may also be attributed to the Arabian red fox, $V$. vulpes arabica Thomas, 1902, which, according to Gasperetti et al. (1985), is ubiquitous in Arabia, being present in large numbers even in the western part of the peninsula. Nor can it be ruled out that individuals of this subspecies may have been introduced by man from Arabia onto the islands off the Red Sea coast of Africa: they may have been pets or used to prevent damage produced by small rodents, such as mice and rats, to human larders (cf. Masseti, 2012). Indeed, in most of the Mediterranean area, $V$. vulpes was the object of particular human attention throughout prehistory since the early Neolithic period, when the canid might have been important symbolically and as food (Masseti, 2012). Alternatively, the fox could have simply walked to Eiro: images from Google Earth (2014) show the presence of mud flats joining the south-eastern corner of the island to the mainland, which suggests that the water there is very shallow and could be crossed during low tide by people, camels, and possibly also foxes.

As far as is presently known, apart from cats and dogs the only carnivore which certainly occurs nowadays on some of the Red Sea islands is the white-tailed mongoose. It has been reported from Dissei, an island off the Buri Peninsula in central Eritrea (De Marchi et al., 2006), and from Farasan Al-Kebir (Jennings, 1988; NCWCD, 2000; Fisher, 2001; Masseti, 2010a). This medium-sized carnivore is the only species of the genus Ichneumia I. Geoffroy Saint-Hilaire, 1837 (Taylor, 1972). It is widespread in sub-Saharan Africa, from Senegal to Sudan and South Africa, and, beyond the Red Sea, to Saudi Arabia (Wozencraft, 2005) (Fig. 8). Scattered records have also been obtained from the Nile valley in Sudan (CloudsleyThompson, 1968) and the southern Arabian Peninsula (Harrison, 1968). It is a very adaptable species of carnivore, which occurs in different habitats, from woodlands to semi-desert, but is not found in swamps, tropical rain forest (Coetze, 1967), nor on mountains above $4000 \mathrm{~m}$ (Taylor, 1972). Man is probably the major predator of white-tailed mongooses, though the young may be subjected to limited predation by large birds of prey (Taylor, 1972). The species could have been imported to the two Red Sea islands by humans, considering that man has often deliberately introduced several species of mongoose onto a number of islands off the coasts of Africa. Populations believed to be originated by introductions are those of the slender mongoose, Galerella sanguinea (Rüppell, 1835), of Zanzibar (Lydekker, 1896; Madon \& Gundevia, 1952; Haltenorth \& Diller, 1977); the small Asian mongoose, Herpestes javanicus (É. Geoffroy Saint-Hilaire, 1818), of the not distant island of Mafia (British Museum Natural History [BMNH] No. 8.6.19.2; Corbet, 1978; Corbet \& Hill, 1992; Wozencraft, 2005; Kock \& Stanley, 2009), and Mauritius (Lever, 1985); and the marsh mongoose, Atilax paludinosus (G. [Baron] Cuvier, 1829), of Pemba (Haltenorth \& Diller, 1977). The Egyptian mongoose, Herpestes ichneumon (L., 1758), has been reported from Madagascar (Corbet, 1978; Lever, 1985; Long, 2003), whereas the Indian grey mongoose, H. edwardsi (É. Geoffroy Saint-Hilaire, 1818), occurs on Mauritius (Hinton \& Dunn, 1967; Corbet, 1978; Wozencraft, 2005). These carnivores are often regarded as efficient predators of poisonous snakes (cf. Masseti, 2009b), but ethnozoological enquiry also documents that they have been utilised to combat the wild and commensal rodents that constitute a serious threat in agricultural and urban areas (cf. Kauhala, 1996; see also Hinton \& Dunn, 1967). They are generally considered to be among the worst invasive species at world level. The white-tailed mongoose is probably the principal factor preventing ground-nesting seabirds from using certain Red Sea islands (Shobrak et al., 2003). On 


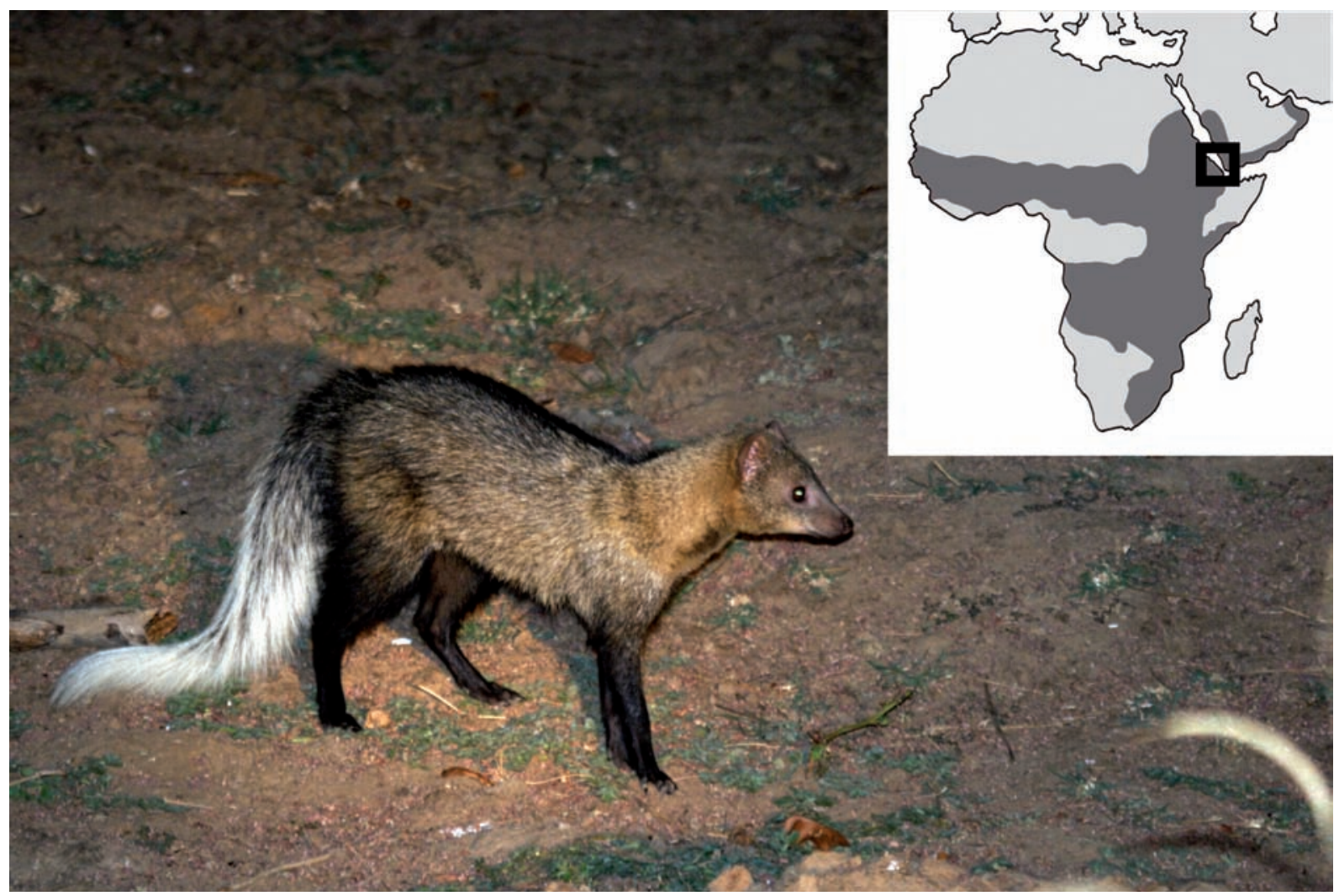

Fig. 8 - A white-tailed mongoose, Ichneumia albicauda, G. [Baron] Cuvier, 1829 (photo by MCSchaeffer, https://creativecommons. org/licenses/by-sa/3.0/, modified) and map showing the geographical location of the Dahlak and Farasan archipelagoes in the context of the general distribution of the species (from Taylor, 2013, modified).

the Farasan archipelago, for example, it has been shown to have a severe adverse effect on the breeding success of the osprey (Fisher, 2001). Furthermore, De Marchi et al. (2006) and De Marchi et al. (2009) suggested a possible relation between the occurrence of this carnivore and the absence of colonies of the crab plover, Dromas ardeola Paykull, 1805, on the Eritrean island of Dissei. The presence of the white-tailed mongoose on the latter island, as well as on Farasan Kebir, can be probably explained as the result of human-mediated introduction. Similarly, the introduction of the small Indian civet, Viverricula indica (É. Geoffroy Saint-Ilaire, 1803) and feral cats to the island of Socotra, off the Horn of Africa, caused the disappearance of all ground-nesting seabird species except for a small number of Saunder's tern, Sterna saundersi Hume, 1877 (Al-Saghier 2000; PERSGA/GEF 2004).

\section{Rodents}

Rodents are exclusively represented by four species commensal with man. The black rat, Rattus rattus (L., 1758), is the most widespread mammal, being reported from at least 19 islands (Rüppell, 1838; Heuglin, 1861; Fitzinger, 1866; Clapham, 1964; The Second Israel South Red Sea Expedition to the Dahlak Archipelago, 1965; Harrison, 1972; Yalden et al., 1976; Evans, 1987; Shobrak et al., 2003; De Marchi et al., 2006; Gladstone et al., 2006; Anderson et al., 2013; present work), and perhaps also from another 8 (the Eritrean islands of Handa, Hant, Dar Solum, Dahaila Seghir, Dasetto, Debel Ali, NN045,
Umm es Sahrig and Umm es Seil: De Marchi et al., 2006; present work) (see: Tab. 2). Reports quote generically the presence of rats on the Farasan archipelago (Gladstone, 2000; NCWCD, 2000; Syed Rafatullah, pers. comm.). The black rat is one of the most adaptable species of rodent and one of the most destructive predators that has ever existed. Today, it is distributed throughout most of the world thanks to human mediation (Atkinson 1985; Cuthbert \& Hilton, 2004; Towns et al., 2006; Howald et al., 2007). It is the most successful island colonist (Martin et al., 2000; Masseti, 2009a), also invading mangrove areas (Mendelssohn \& Yom-Tov, 1999). On the Red Sea islands, the black rat is known to prey upon the eggs and chicks of marine birds (Evans, 1987; De Marchi et al., 2006; Clapham, 1964). It is a water-dependent, omnivorous species (Wranik, 2003), and is also an excellent swimmer that can feed on fish and snails (Bath-Sheba, 1932; Harrison, 1972). Consequently, it cannot be excluded that black rats avoid territories without a permanent fresh water supply. However, reduced availability of fresh water does not appear to prevent the diffusion of the rodent. The uninhabited island of Darsah $\left(5.412 \mathrm{~km}^{2}\right)$, for example, in the Yemenite archipelago of Socotra, about $300 \mathrm{~km}$ off the Horn of Africa in the Indian Ocean, is a dry rock, apparently without any permanent fresh water supply (Eike Neubert, pers. comm.). It is known, however, to be inhabited by an enormous population of black rats (Massa'a al Jumaily and Abdul Karim Nasher, pers. comm.). The intense infestation of these rodents has cau- 
sed serious mortality of sooty gulls, Ichthyaetus hemprichii (Bruch, 1853), and desertion of the breeding colony (Gladstone et al., 2006).

House mice appear to be less dispersed than black rats, having been recorded from a distinctly smaller number of islands (Cretzschmar, 1830; Heuglin, 1861; Brehm, 1863; Heuglin \& Fitzinger, 1866; Osborn \& Helmy, 1980; present work). In the Dahlak archipelago, the species was recently recorded by one of the authors (GDM), who found only a recently dead specimen on the tiny island of Dahret in 2010 (Fig. 9). Extensive research carried out on

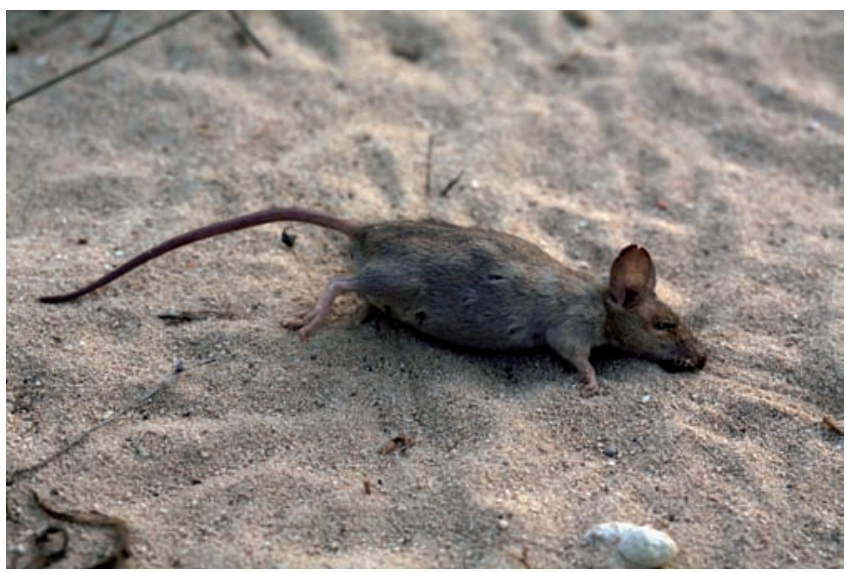

Fig. 9 - A dead house mouse, Mus musculus L., 1758, photographed on the island of Dahret, in the Dalhak archipelago, in 2010 (photo by Giuseppe De Marchi).
Dahret did not find any other specimen of this rodent, not even prints on the largely dusty surface of the island, suggesting that the species possibly went extinct. The house mouse is evidently a commensal of man which has considerably extended its distribution through human agency, but on semi-desert islands it can hardly survive outside anthropogenic settlements. Its extinction on Dahret island might be an example of this.

Eastern spiny mice, Acomys dimidiatus (Cretzschmar, 1826), were trapped by Iyad A. Nader for the first time on the Red Sea island of Farasan Kebir, on 18 November 1983 (Masseti, 2010a). About 30 years later, in February and March 2010, several representatives of another spiny mouse species, the Northeast African spiny mouse, Acomys cahirinus (É. Geoffroy, 1803), were collected by one of the authors (GDM) on the island of Dur Ghella in the Dahlak archipelago (Fig. 10).

The brown rat has been recorded only once, by De Beaux (1930-31) from the island of Fatmah, which is located in the bay of Assab, in southern Eritrea. According to Al-Jumaily (1998), this species does not occur within the Yemenite political borders either, from where only $R$. rattus has been recorded to date. The brown rat is much more dependent on freshwater than the black rat, and the extreme dryness of the Red Sea islands may be among the main causes of the absence of this species from the majority of these. Yalden et al. (1976) observed that the species is restricted in Ethiopia '... to coastal areas and probably dependent upon shipping for its continued occurrence in this country'.

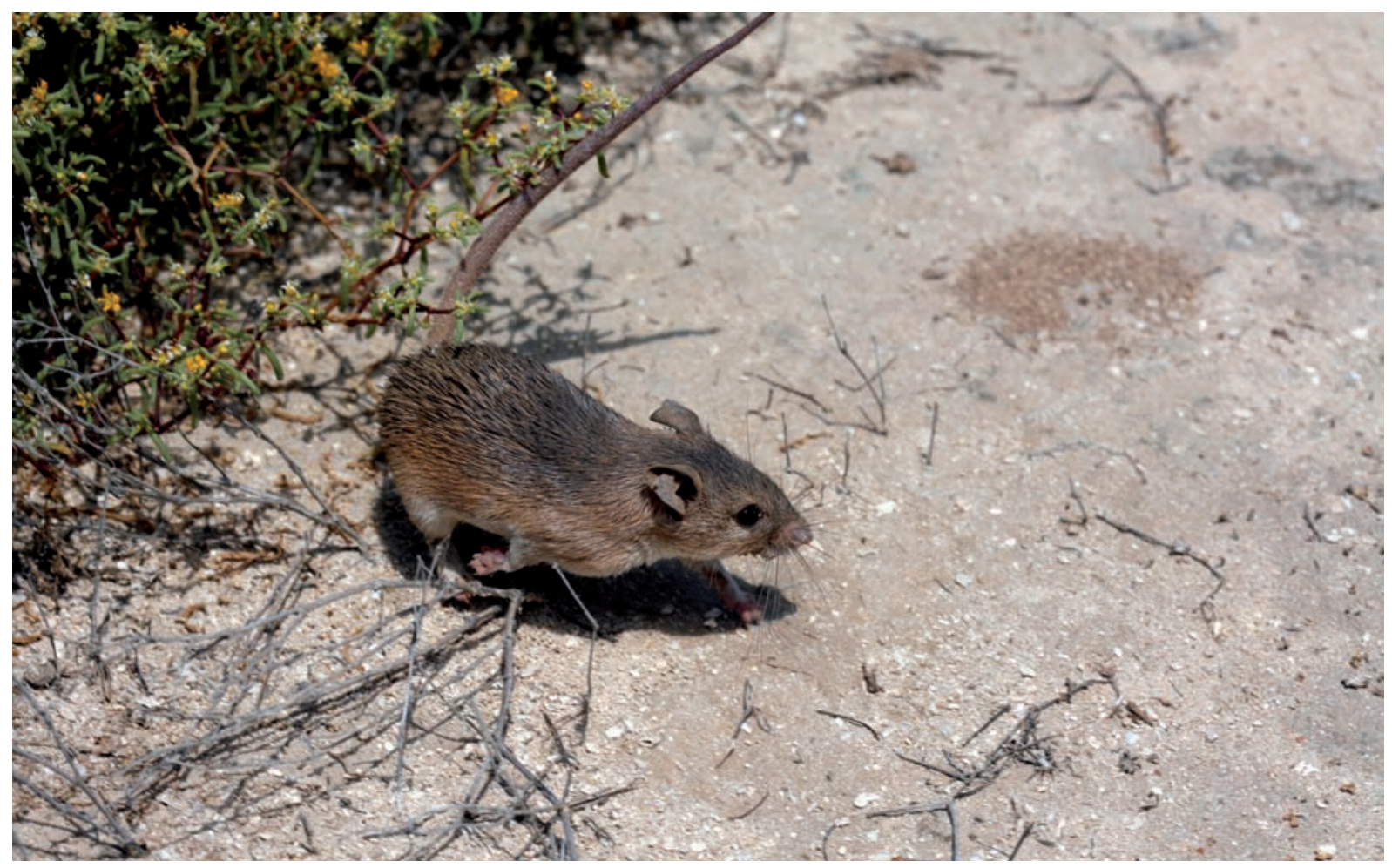

Fig. 10 - Northeast African spiny mouse, Acomys cahirinus (É. Geoffroy, 1803), photographed on Dur Ghella island (Dahlak archipelago, Eritrea). The range of this species is basically west of the distribution of the morphologically similar Eastern spiny mouse, $A$. dimidiatus (Cretzschmar, 1826), which is distributed from the Sinai peninsula and the Levant to the Middle East (photo by Giuseppe De Marchi). 
Jesse C. Hillman reported the occurrence of an unidentified 'very pale rodent' on Dohul, in the same Eritrean group of islands (unpublished report: 12 February 1993)

\section{Shrews}

To date, known representatives of the Soricidae family are very few in number on the Red Sea islands. The tiny Sahelian shrew, Crocidura pasha Dollman, 1915, was reported by Kock (1980) from Sawākin. This shrew is distributed to Sudan and the Sahelian savannah of Sudan and Mali, with a single record from Ethiopia (Hutterer, 2005). The Asian house shrew, Suncus murinus (L., 1766), has been recorded on Sawākin (Heuglin, 1877; Anderson \& De Winton, 1902; and Kock, 1980), on the Dahlak islands (Heuglin, 1861), where it was observed to be quite common, on Massawa and Dahlak Kebir (Rüppell, 1840; Del Prato, 1891; Sordelli, 1902; Parisi, 1917; Yalden et al., 1976; Kock, 1980), and on Massawa (Heuglin, 1861; Parisi, 1917), where both authors identified the soricid with the former taxonomic name of Crocidura (Pachyura) crassicaudata (Lichtenstein, 1834).

A last addition, the skull of a small soricid (Crocidura sp.), now kept at the Museo di Storia Naturale di Milano (MSNM Ma 7901), was found by GDM in 1999 in a barn owl pellet in a cave on Isratu island, Dahlak archipelago.

\section{Gazelles}

Gazelles are the only wild ungulates occurring on the Red Sea islands. These gazelles essentially belong to two taxonomic groups: Gazella de Blainville, 1816, and Nanger Lataste, 1885. Three species of the genus $G a-$ zella have been recorded to date: the dorcas gazelle, $G$. dorcas (L., 1758), on Sawākin (BMNH 97.12.21.1) and Massawa (MSNG 1458 and 1463); the mountain gazelle, G. gazella (Pallas, 1766), in the Farasan archipelago (Thouless, \& Al Bassri, 1991; Masseti, 2010a; Lerp et al., 2013; Wronski, 2013) as well as on al-Hanish alKabir (Dollman, 1927; Al-Jumaily, 1998), and possibly Sumayr (cf. Bruce of Kinnaird, 1790) (Fig. 11); and the enigmatic $G$. arabica, once seemingly found in the $\mathrm{Fa}$ rasan archipelago, but also on the nearby Arabian coast (ZMB MAM 2115).

In contrast, Soemmerring's gazelle (genus Nanger) occurs only on Dahlak Kebir (Fig. 12). The earliest record of gazelles from the Dahlak archipelago was by Bruce of Kinnaird (1790) during his visit to Dahlak Kebir in September 1769 (cf. Benardelli, 2004). Later, Henry Salt (in Annesley Mountnorris, 1811) reported the killing of a gazelle on Dahlak Kebir at the beginning of the $19^{\text {th }}$ century (sometime between 1804 and 1806): 'It was eleven o'clock before we got away we saw many deer [sic!] on the road and by accident caught a doe big with young that

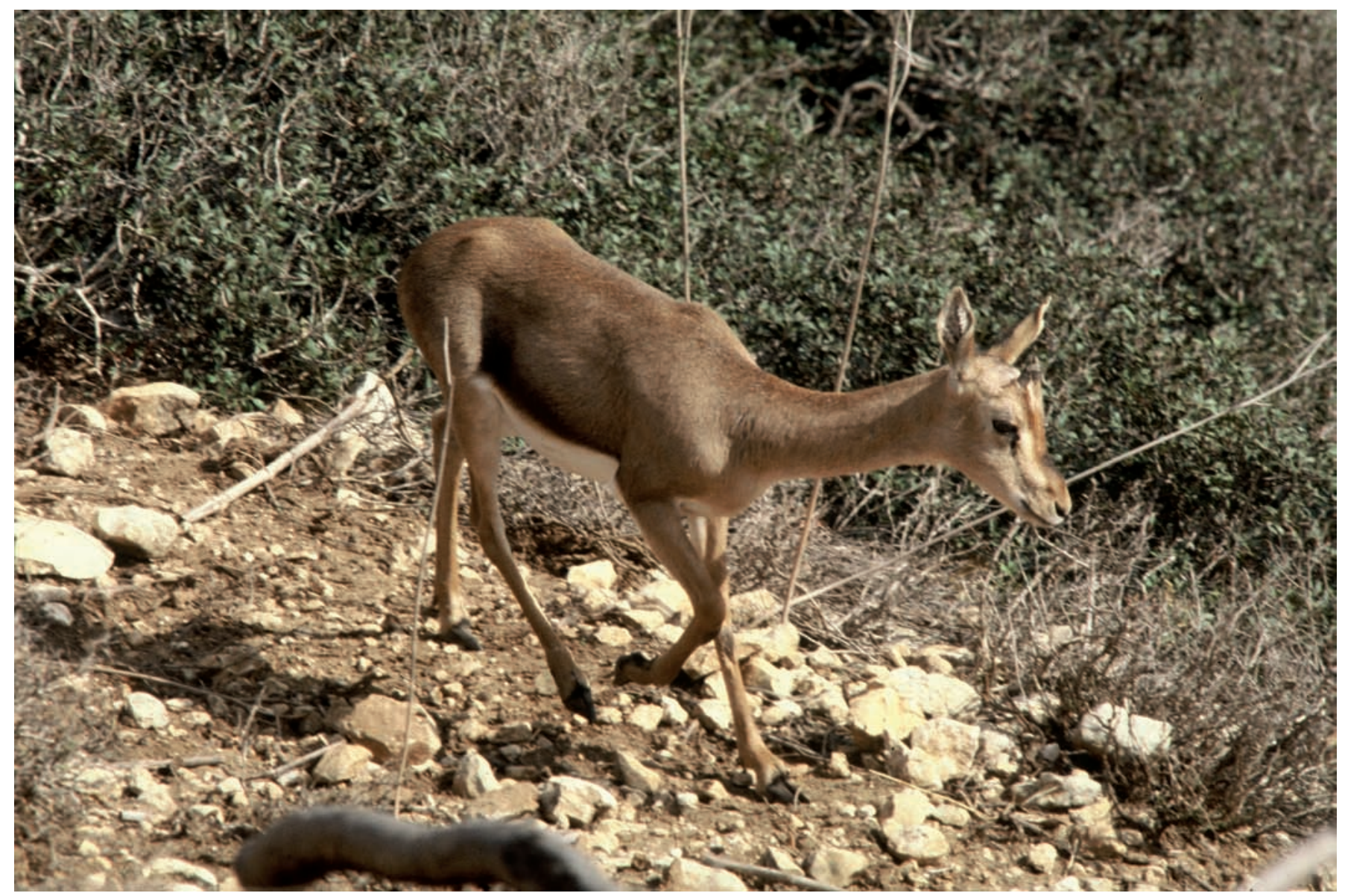

Fig. 11 - Populations of mountain gazelle, Gazella gazella (Pallas, 1766), still occur on several islands of the Farasan archipelago (Farasan Al-Kebir, Segid, Zifaf or Sarso, Qummah, and perhaps Dumsuq), as well as al-Hanish al-Kabir and, possibly, Sumayr (photo by Marco Masseti). 


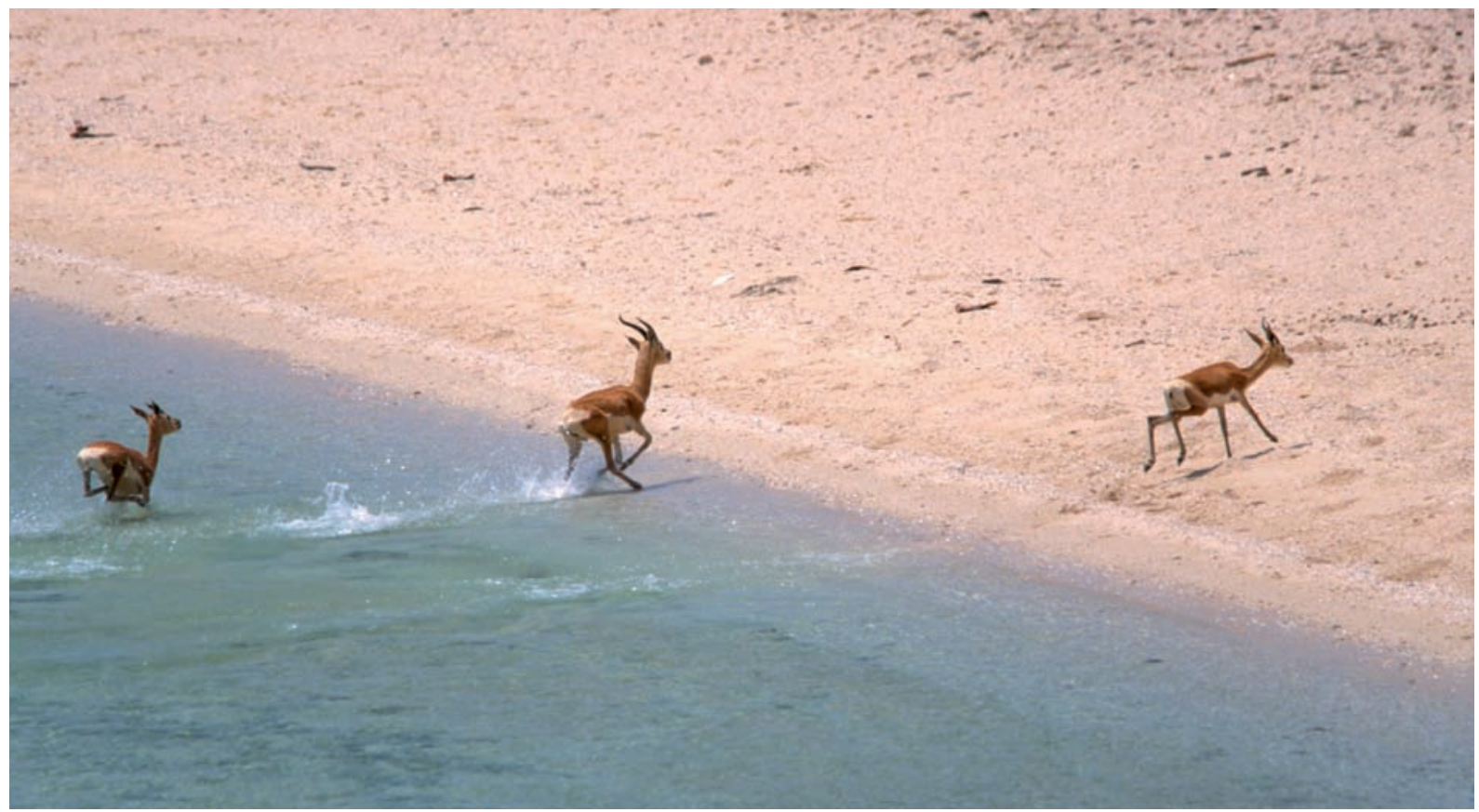

Fig. 12 - In the Dahlak archipelago, Soemmering's gazelle, Nanger soemmerringii (Cretzschmar, 1828), is found only on the larger island, Dahlak Kebir (photo by Giuseppe De Marchi).

had been previously wounded. She was large of a light dun colour white on the belly and rump with small black horns which were circled with rings'. Ehrenberg (1827) reported that the hunters who accompanied him in 1825 thought the ungulates that occurred there were mountain gazelles. The occurrence of Soemmerring's gazelle on Dahlak Kebir was first recorded by Rüppell (1838) and then by Heuglin (1861) (cf. Chiozzi et al. 2014b). However, Baschieri Salvadori, the zoologist of the 1953 Spedizione Subacquea Italiana nel Mar Rosso (Baschieri 1954; Baschieri Salvadori, 1954), considered them to be Gazella isabella Gray, 1846, a synonym of G. dorcas (see Grubb, 2005). It was formerly also classified at the subspecific level of the latter species: G. dorcas isabella (Groves, 1997). The dorcas gazelle extended from North Africa to the Levant. However, he did not collect a specimen to support his claim (Yalden et al., 1996). We cannot exclude that the species in the gazelle population changed between 1861 and 1953, or that Baschieri Salvadori's report is inaccurate. Torunsky et al. (2007) initially suggested that the gazelles of Dahlak Kebir may also be more closely related to the Saudi gazelle, Gazella saudiya Carruthers and Schwarz, 1935, a species originally endemic to the western parts of the Arabian Peninsula, but recently (2008) declared extinct. However, the same authors later rejected the assumption, confirming the occurrence of $N$. soemmerringii on Dahlak Kebir (Torunsky et al., 2010).

More recently, reports on the island of Dahlak Kebir refer the local gazelles to $N$. soemmerringii, albeit to a dwarf variety very likely arising from the "island rule" effect (Bolton, 1973; Chiozzi et al., 2014a; Kingdon, 1982; Yalden et al., 1984; Yalden et al., 1996; De Marchi, 2004) (Fig. 13). The unsettled issues concerning the specific identification of the extant gazelles of Dahlak Kebir com-

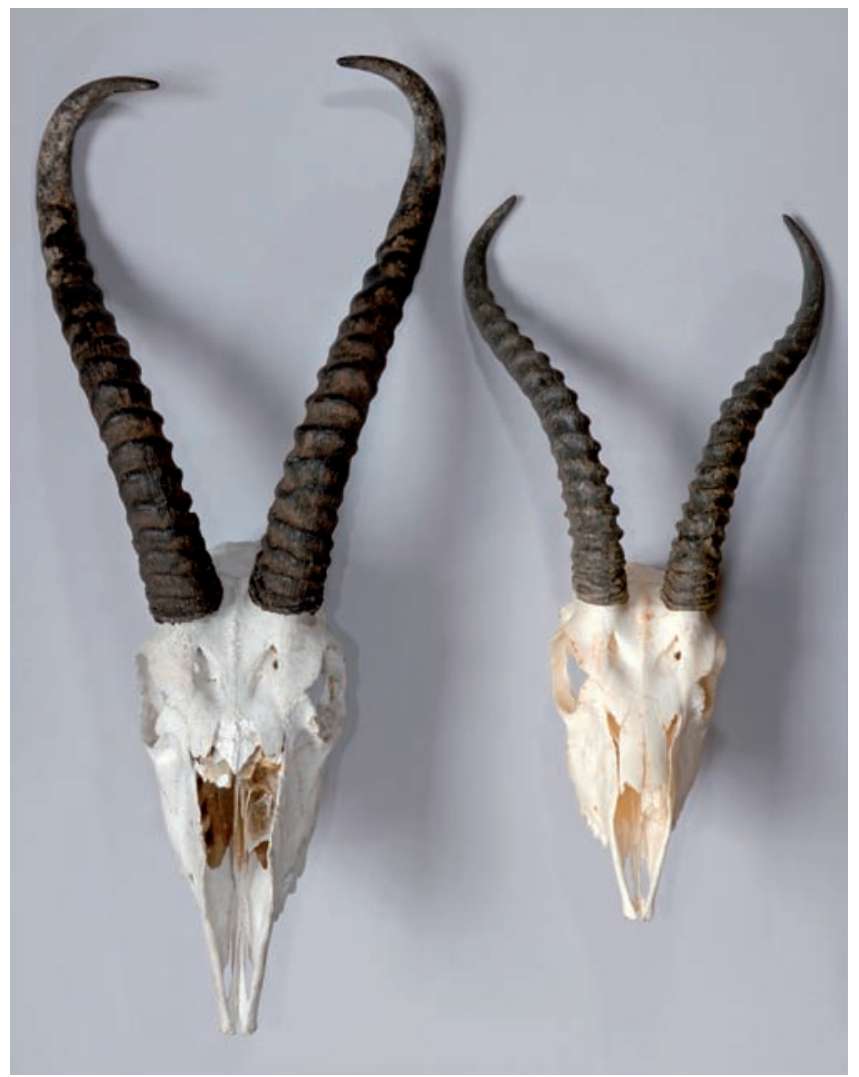

Fig. 13 - Soemmerring's gazelle, Nanger soemmerringii (Cretzschmar, 1828 ), is present on the island of Dahlak Kebir with a variety of reduced dimensions, very likely caused by the "island rule" effect. The size difference between a continental subspecies (N. s. berberana Matschie, 1893) and the insular population is clearly shown here by the skulls of two adult males of comparable age (photo by Giorgio Bardelli; Museo di Storia Naturale di Milano). 
pared with those that may have inhabited the island in the past could be partly solved based on historical grounds. In a recent interview conducted by one of the authors (GDM, 6 July 2010), the last governor of the Dahlak archipelago, Taha Siraj - who was in office for some years until 1991 and was the son of the previous governor - asserted that Dahlak Kebir's population of gazelles had faced serious problems of survival during the years of his service. Furthermore, at the time of his father's tenure, the ungulates seemed to have become extinct, or had become extremely rare on the island, so much so that the governor decided to import other gazelles from the mainland coast. Taha Siraj recalls that some stocks were also introduced to other islands, perhaps Shumma and Dur Ghella, but unsuccessfully, as they failed to survive. He does not remember, however, when the introductions actually occurred. Consequently, it cannot be ruled out - as suggested by Kingdon (1990) for the ambiguous origin of the extant Farasan gazelles - that the original population of Dahlak Kebir has also been replaced by new stocks and new species from the mainland, or that crossings took place with the new introductions even over recent historical times. Indeed, the nearby Farasan islands, off the southern Saudi Arabian coast, are today characterised by an endemic subspecies of gazelle, the Farasan mountain gazelle, $G$. g. farasani Thouless \& Al Bassri, 1991 (Flamand et al., 1988; Thouless \& Al Bassri, 1991; Masseti, 2010a), but with phenotypical patterns somewhat different from the ungulate originally reported from the archipelago and previously designated as the Farasan gazelle, Gazella arabica (Lichtenstein, 1827). The latter, enigmatic ungulate was in fact indicated as a separate species restricted to the Farasan insular range (Dollman, 1927; Groves, 1983). According to Kingdon (1990), it cannot be excluded that the original population has been replaced by new stocks from the mainland, or that crossings occurred with new introductions over the last 160 years. The taxonomic status of the gazelles now present on Dahlak Kebir has raised an extensive debate within the international scientific community, which has been summarised in Yalden et al. (1996). A dwarf subspecies of $N$. soemmerringii had been already identified by A.W. Gentry, based on a single specimen from Dahlak Kebir (Bolton, 1973; Yalden et al. 1996). This insular population may likely form a yet undescribed subspecies (Gippoliti, 2013). Based on photographs (De Marchi, 2002, 2004) and careful morphometric comparisons (Chiozzi et al., 2014a), it is quite small sized, and with horns in the male similar to those of the already mentioned Somali subspecies, $N$. s. berberana (Matschie, 1893) (Fig. 14), but with the tips only slightly curved inwards and without the characteristic hook (Oriani \& Castiglioni, 2003). Sequences of cytochrome b mitochondrial DNA also confirmed that these gazelles are a dwarf variant of the larger mainland Soemmerring's gazelle, suggesting that this island population may have been established not long ago from a small subset of

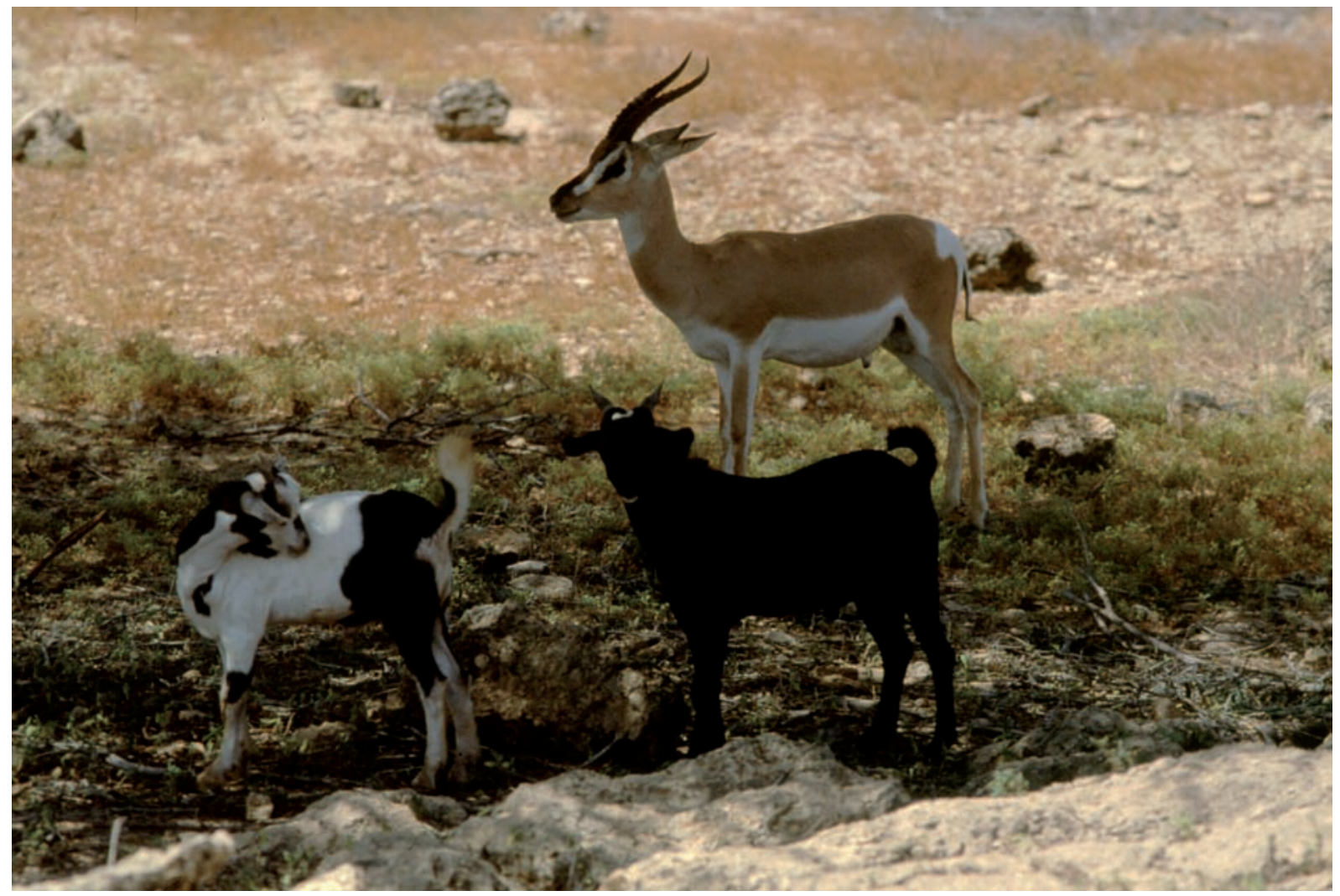

Fig. 14 - In the foreground, two sub-adult domestic Somali goats, once widely known also as Galla (male, black; female, spotted). Both seem not to exceed $70 \mathrm{~cm}$ at the withers. This is approximately the height also of the Soemmerring's gazelle, Nanger soemmerringii (Cretzschmar, 1828), in the background, which is in contrast with the range of the species (between $81 \mathrm{~cm}$ and $98 \mathrm{~cm}$ ) (see: Dorst \& Dandelot, 1969; Funaioli, 1971; Haltenorth \& Diller, 1977; and Kingdon, 2004) (photo by Giuseppe De Marchi). 
mainland animals (Torunsky et al., 2007; Torunsky et al., 2010; Kamal M. Ibrahim, 2010; pers. comm.). On Dahlak Kebir, this arid-adapted gazelle has practically no predator. Ospreys occasionally use the ungulate bones for the construction of their nests where, according to Roghi \& Baschieri (1954), osteological remains of the gazelles have sporadically been found (Fig. 15). The local abundance of gazelles and the presence of villages also allows local persistence of a population of winged scavengers, such as the Egyptian vulture, Neophron percnopterus (L., 1758) and the hooded vulture, Necrosyrtes monachus (Temminck, 1823) (De Marchi et al., 2009).

Another enigma is the past presence of the above-mentioned gazelle on the Farasan archipelago. So far, the only endemic mammal known on the Red Sea islands is the Arabian gazelle, G. arabica (Lichtenstein, 1827), which was originally reported from the Farasan islands (Masseti, 2010a). This intriguing ungulate is known only from a single male specimen preserved in the Berlin Museum (ZMB MAM 2115, skull and skin labelled: "Type" of $G a-$ zella arabica Hemprich and Ehrenberg) (Lydekker, 1914; Masseti, 2010a) (Fig. 16). It was apparently collected by Hemprich and Ehrenberg in 1825 (Neumann, 1906; Harrison, 1968; Groves, 1983, 1985), but the specimen may not actually come from the Farasan. Therefore, its former di- stribution and status may never be known (Groves, 1983; Mallon \& Kingswood, 2001; Mallon \& Hoffman, 2008). Originally described as Antilope arabica by Lichtenstein (1827-1834), it was later indicated as the type of G. arabi$c a$ by Neumann (1906), who in stating that the specimen was from Farasan may have had information now unavailable to us (Groves, 1983). This male was indicated as the type of a distinct species restricted to the Farasan insular range (Dollman, 1927). In fact, the skull dimensions and horn shape of the male lectotype of G. arabica are very different from all other known gazelle species (Groves, 1983; cf. Grubb, 2005). It was even suggested that its unique skull morphology was the result of pathological deformation (Groves, 1983). On the other hand, some suggest a possible analytical error in the origin of the Berlin gazelle. On 30 April, 1825, C.G. Ehrenberg wrote to H. Lichtenstein from Massawa that, together with F.G. Hemprich, he had collected a gazelle on Farasan Kebir, but he failed to indicate the sex or any other data (Groves, 1983). Later, Hemprich \& Ehrenberg (1828) included this Arabian specimen with two others from the Sinai, but without distinguishing the specimens from the two localities. Neumann (1906) was the first to query the inclusion of the Hemprich and Ehrenberg specimens in the same taxon. He identified the type of Gazella arabica as 'an old buck

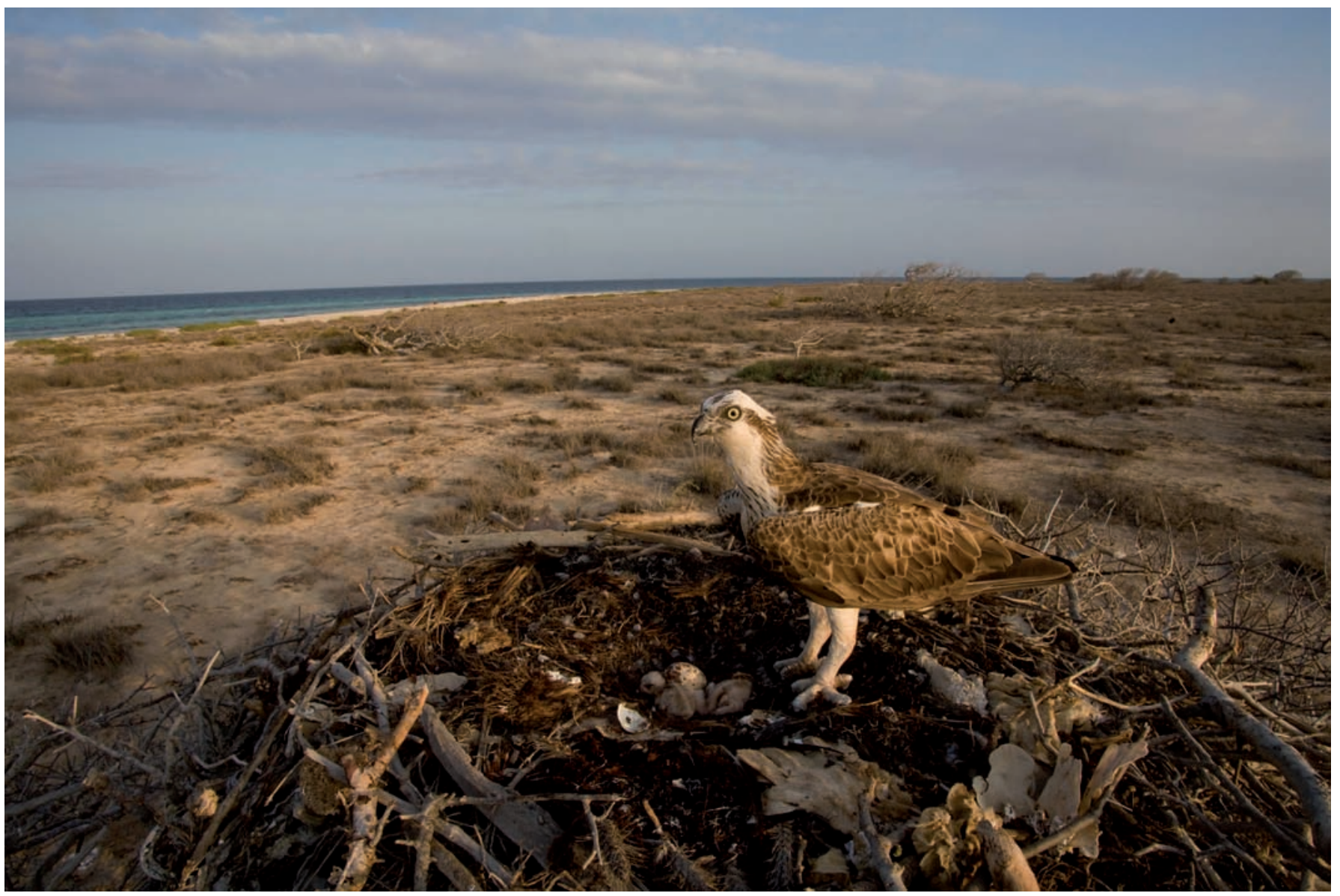

Fig. 15 - Soemmerring's gazelles, Nanger soemmerringii (Cretzschmar, 1828), have practically no predator on the island of Dahlak Kebir. However, because ospreys, Pandion haliaetus (L., 1758), sometimes use their bones as building material for their nests, some authors have hypothesised that these birds, which are notoriously piscivorous, can occasionally prey upon the gazelles (see Roghi \& Baschieri, 1954) (photo by Giuseppe De Marchi). 
from Farasan Island, no. 2115, in the Berlin Museum'. Surprisingly, in a recent study of the skull and skin of the lectotype - which had so far been considered belonging to a single individual - the two items were found to come from different specimens (Bärmann et al., 2013). The skull sequence is nested within the clade of northern G. gazel$l a$, and likely comes from Israel (Bärmann et al. 2013) or Syria (Bärmann et al., 2014), while the skin sequence is nested within the southern (or Arabian) G. gazella; the latter matches the genetics of the gazelles now inhabiting the Farasan archipelago, which are regarded as a distinct subspecies, G. g. farasani Thouless \& Al Bassri, 1991, of the mountain gazelle (Wronski et al., 2010) (Fig. 17). Therefore, we have no evidence supporting that other gazelle species inhabited the Farasan archipelago except the present G. g. farasani. In fact, if we exclude the lectotype, no other specimens were ever confidently assigned to $G$.

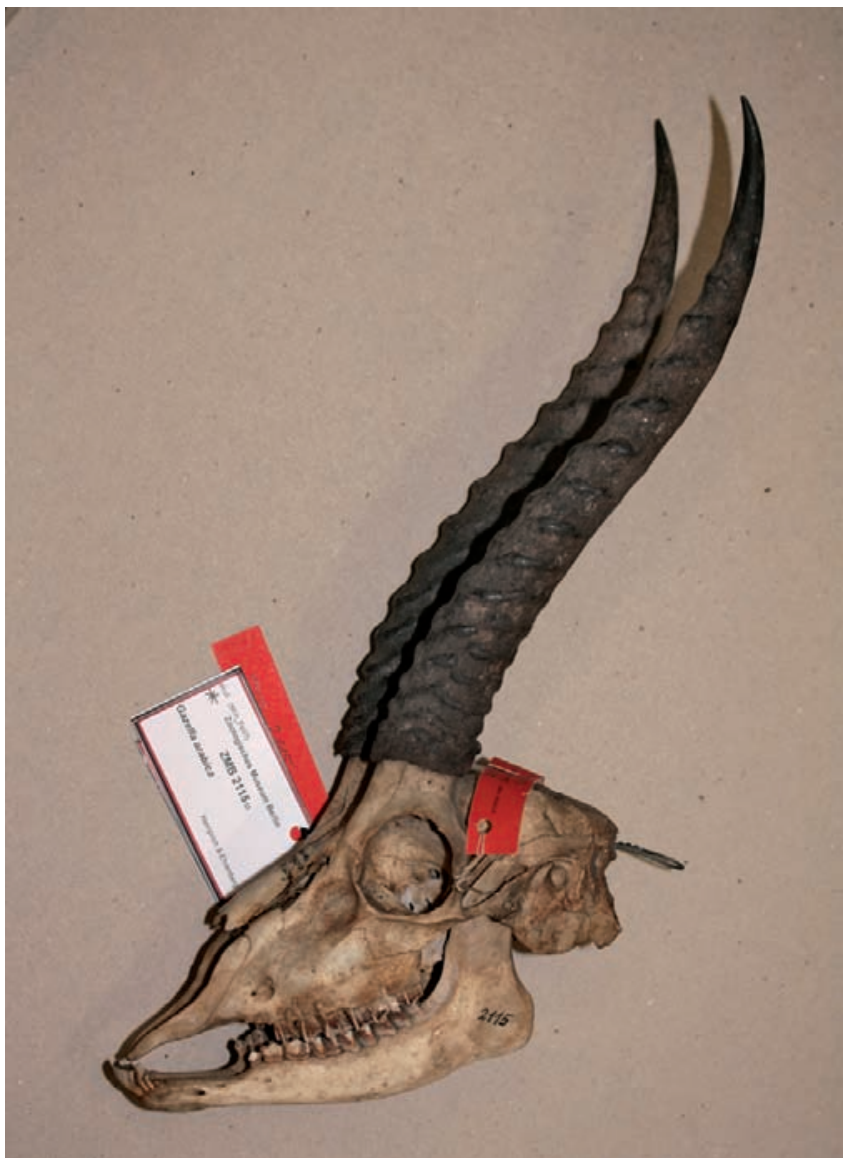

Fig. 16 - The type of the misterious Arabian gazelle, Gazella arabica (Lichtenstein, 1827), includes this skull and a skin, both designated with catalogue number ZMB_MAM_2115 (Museum für Naturkunde, Berlin). The German explorers Hemprich and Ehrenberg seemingly collected the specimen in the Farasan islands in 1825 . However, recent genetic evidence suggests that while the skin comes from a Farasan gazelle, the skull is that of an Israeli or Syrian mountain gazelle. Probably, there was a mistake in the past in assigning skull and skin to the same individual. This combination of specimens from different sources originated the type now preserved in Berlin. Recently, Bärmann et al. (2014) proposed to consider only the skin of ZMB_MAM_2115 as the lectotype of Antilope arabica Lichtenstein, 1827 (courtesy of Museum für Naturkunde Leibniz Institut for Research on Evolution and Biodiversity at the Humboldt University, Berlin). arabica. Therefore, the taxonomic status, distribution and phylogenetic relationships of this enigmatic species is likely to remain unknown (Bärmann et al., 2013). On the other hand, as might have happened on Dahlak Kebir, we cannot rule out that the Farasan gazelle population may have been restocked by humans with different species over time.

\section{Insular dwarfism}

Interestingly, the gazelles presently found on Dahlak Kebir and on the Farasan archipelago are dwarf compared with their mainland counterparts (Thouless \& AlBassri, 1991; Wronski \& Cunningham, 2010; Chiozzi et al., 2014a, 2014b). Insular dwarfism is a very common phenomenon in large mammals, possibly due to genetic isolation from continental populations, quantitative and qualitative reduction in food supply, alteration of intraspecific competition, and absence of large carnivores (cf. Masseti \& Mazza 1996; Masseti, 2009a). Dwarfism appears to be the only evolutionary option available to largesized animals to lower selective pressure when they move into insular settings (Mazza, 2007 and references therein). In ungulates, reduction of size and simplified horn development have often been interpreted as the consequence of prolonged isolation in restricted areas of low trophic production, combined with the effects of genetic bottlenecks and of continuous consanguinity (Lister, 1989; cf. Masseti \& Zava, 2002).

On islands, body size reduces quite rapidly. According to Azzaroli (1977), size can drop in just a few millennia, but it can occur in an even shorter time. For example, when the small red deer, Cervus elaphus hispanicus Hilzmeier, 1909, of the Marismas of the river Guadalquivir, in southern Spain, was transferred to areas with higher food availability - such as the Asturias, the Sierra of Cadiz, or the Sierra Morena - individuals of definitively larger dimensions and a more complex antler architecture developed in just a few years (cf. Delibes de Castro et al., 1990).

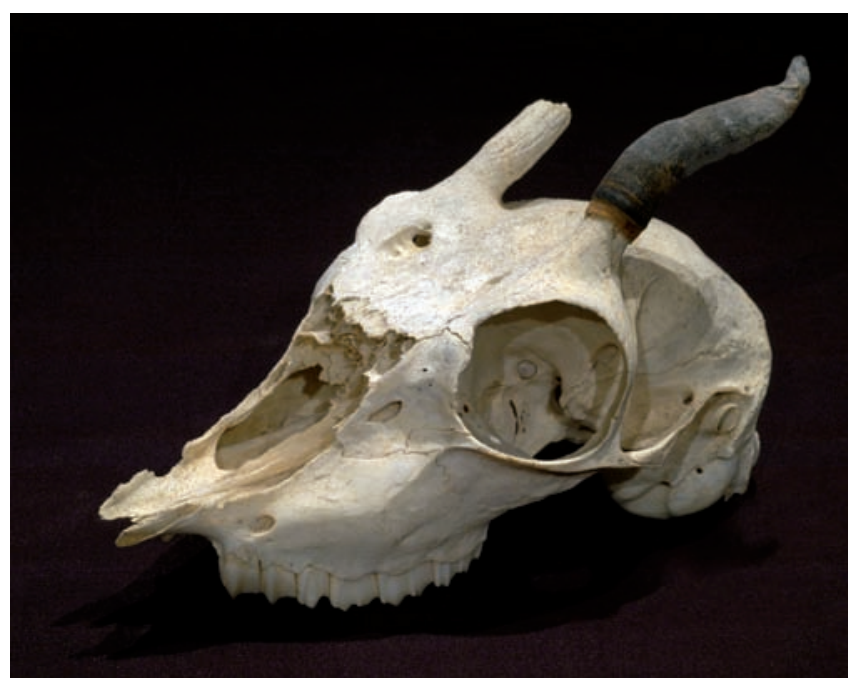

Fig. 17 - Skull of an adult female of the extant Farasan gazelle, Gazella gazella farasani Thouless \& Al Bassri, 1991 (catalogue number: MZUF 11330, Zoological Museum, University of Florence) (photo Saulo Bambi; courtesy of the Museo di Storia Naturale dell'Universita di Firenze, Sezione di Zoologia "La Specola", Florence). 
The fossil record from the Island of Jersey suggests that the populations of red deer that had been newly introduced from the mainland became adapted shortly after isolation (Lister, 1989, 1996). Research on the European mouflon Ovis orientalis Gmelin, 1774, from the Kerguelen Islands (Bousses \& Reale, 1996) and on the feral domesticated sheep from Santa Cruz Island, California, (Van Vuren \& Bakker, 2009) also indicated that some morphological traits (body mass and wool traits) may have changed in just 25-90 years, which correspond to an extraordinarily low number of generations in these large animals (cf. Chiozzi et al., 2014a). The woolly mammoth, Mammuthus primigenius (Blumenbach, 1799), turned dwarf between 7000 and $4000 \mathrm{yr} \mathrm{BP}$ on Wrangel islands, in the Arctic Ocean (Lister, 1993, Vartanyan et al., 1993).

The geological history and the geographical location of many of the islands considered in the present study suggest that gazelles may have been already present on the Farasan islands and on Dahlak Kebir when the Holocene eustatic rise in sea level detached these islands from the mainland. However, in the absence of a fossil record, we consider more likely that the extant insular populations are the result of human introduction. Gazelles were very likely introduced to most of these islands for hunting and to provide a source of fresh meat (Masseti, 2009b, 2010b). Examples of this type of game management are known in the Arabian area since prehistoric times (cf. Karami \& Groves, 1993; Tomé, 2003). Indeed, animals the size of a deer can be shipped long distances quite easily, even on small, primitive boats (cf. Clutton-Brock, 1981). Once released into the new territories, the continental Soemmerring's gazelles originated a free-ranging population, the descendants of which still live there today. Once back in the wild, the phenotypical patterns of their continental ancestors were modified and they became dwarf. The gazelles have survived only on Dahlak Kebir, perhaps because it is large enough to maintain sufficiently numerous herds and, thus, avoid the effect of fluctuations induced by human exploitation (cf. Rüppell, 1838), recurrent droughts (cf. Chiozzi et al., 2014b), genetic drifts, as well as the unpredictable spread of epidemics.

\section{Biogeography of the Red Sea islands}

Altogether, very few endemic terrestrial vertebrate taxa are known to date on the Red Sea islands. For example, no endemic species is present on these archipelagoes, based on the checklist of the additional data on the insular mammalian species of the world proposed by Alcover et al. (1998). The same can be said for local sea birds. The only near-endemic avian species is the white-eyed gull, Larus leucophthalmus Temminck, 1825, which, however, is also found in the Gulf of Aden, and could have colonised the Red Sea from there after the Last Glacial Maximum, when the Red Sea was unsuitable for marine life because of its increased salinity (Braithwaite, 1987; De Marchi et al., 2009).

The relative paucity of endemic terrestrial vertebrates from the Red Sea archipelagoes is quite surprising indeed. As far as is presently known, there are only three endemic species of snake, and, perhaps - as we have seen above one gazelle, the already mentioned Gazella arabica. The
Sarso island racer, Platyceps insulanus Mertens, 1965, is known only from a single specimen captured by W. Kost along the coast of the island of Sarso, a low-lying coral atoll of the Farasan archipelago, in November 1964 during the "Meteor" Expedition launched by the SenckenbergMuseum in the Indian Ocean (Mertens, 1965) (Fig. 18). The holotype specimen is now preserved at the Senckenberg Museum in Frankfurt (SMF 60027: 1 male adult, W. Kost, Saudi Arabia, 26/11/1964) (Fig. 19). Based on Kost's report, but also on the subsequent taxonomic description by Mertens (1965), the snake has never been seen again since, either on Sarso or on other nearby islands (Masseti, 2014). Hence, the endemic Sarso island racer is known only from the holotype and a sloughed skin. Its unclear status, however, has led several authors, such as Leviton et al. (1992) and Egan (2007), to omit it from their checklists of Arabian herpetofauna. Some doubts

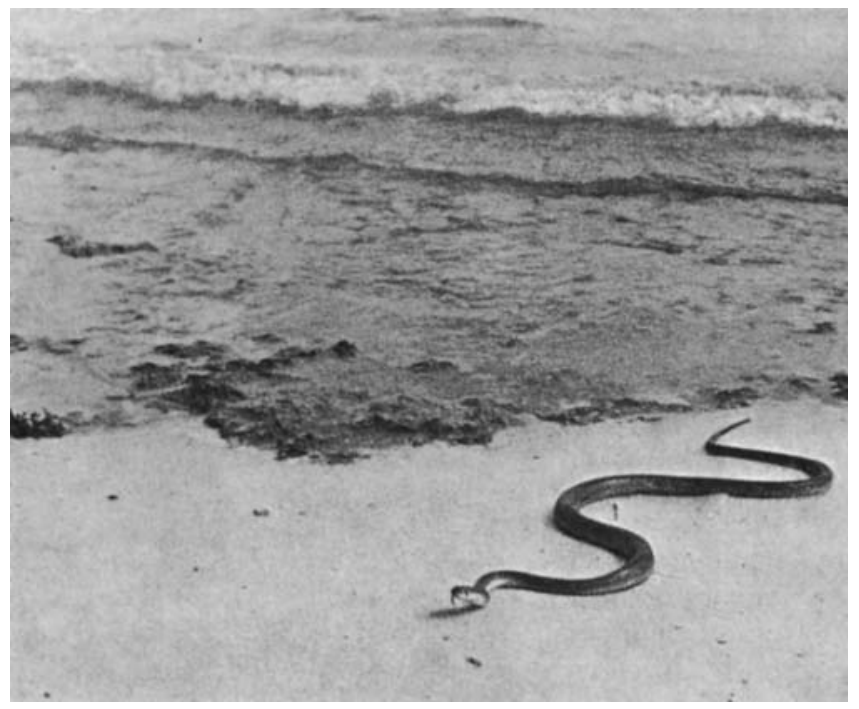

Fig. 18 - The Sarso island racer, Platyceps insulanus (Mertens, 1965), photographed in November 1964 on the namesake island of the Farasan archipelago during the "Meteor" Expedition in the Indian Ocean launched by the Senckenberg-Museum (from Mertens, 1965).

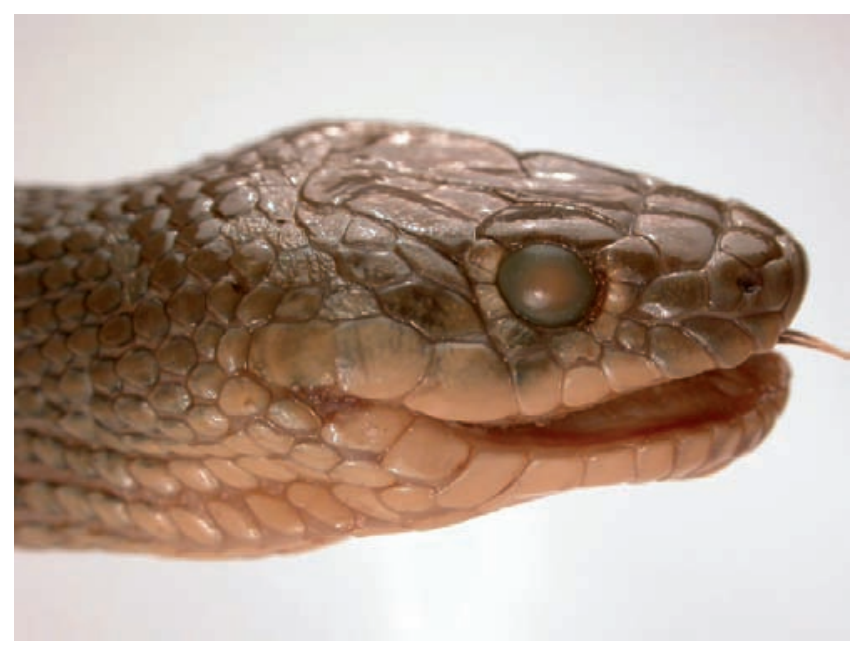

Fig. 19 - The holotype of Platyceps insulanus (Mertens, 1965) (catalogue number: SMF 60027, Senkenberg Museum, Frankfurt) (photo by Michael Franzen; courtesy of Senkenberg Museum, Frankfurt). 
have also been raised on where the Sarso island racer had actually been collected. For example, Gasperetti (1988) observed that Mertens (1965) reported P. insulanus from what he believed to be Sarso, i.e., an island of the Dahlak archipelago, whereas in fact it is part of the Farasan islands. Moreover, the fact that a specimen of the same species was captured during an expedition in the Indian Ocean raises further doubt upon the real locality of its provenance. Alternatively, P. insulanus really does inhabit Sarso island, and the lack of additional findings is just due to the difficulty in catching this snake.

Another endemic [?] representative of the genus Platyceps, the Dahlak racer, Platyceps largeni (Schätti, 2001), has been described from the small islands of Andeber, Nocra, and Sarad in the Dahlak archipelago (Schätti, 2001; Largen \& Spawls, 2010). According to Schätti (2001), however, the species is probably more widespread in the archipelago than is presently known. The recent identification of a sixth specimen among the material collected on Museri Island in 1965 during the Second Israel South Red Sea Expedition and kept at the Natural History Collections of Tel-Aviv University (labelled TAU-R.16164), confirms Schätti's prediction (Maza et al., 2015). The holotype of the species, a female (collected by M. J. Largen on January 7, 1970), is kept at the Natural History Museum of London (labelled BMNH 1973.3211). Yet another endemic species from the southern Red Sea is a variety of viper, the bigheaded carpet viper, or Cherlin's saw-scaled viper, Echis megalocephalus Cherlin, 1990 (Cherlin, 1990; McDiarmid et al., 1999; Schätti, 2001; Largen \& Spawls, 2010). This snake is known only from four specimens collected in its type locality, originally indicated by Cherlin (1990) as 'an island in the southern Red Sea'. It is supposedly the island of Nocra (Joger, 2010) or, perhaps, Dissei (Largen, 1997). Its type series was obtained by a Soviet Navy surgeon (Schätti, 2001). Most probably, the type locality of $E$. megalocephalus is just Nocra, a former Soviet naval base (Borkin \& Cherlin, 1995). Remarkably, no endemic lizard is known from this region (Schätti, 2001).

The Red Sea islands have undoubtedly homogeneous continental mammalian faunas. This suggests a common origin of the communities from the mainland of eastern Africa and/or the western Arabian Peninsula, apparently depending on the distance of the islands from the two shores. Acomys dimidiatus and Gazella gazella colonised the islands close to the Arabian coast, whereas Acomys cahirinus and Nanger soemmerringii colonised the islands close to the African coast. Other widespread species are present on the islands on both sides of the Red Sea. This is the case, for example, of the white-tailed mongoose, the black rat and the house mice. The biodiversity is low; in fact, the communities include very few species. Whereas the absence of some groups can be easily explained by the lack of a suitably large habitat (e.g., ungulates) or by human interference (e.g., medium-sized carnivores), the complete absence of smaller species well represented in the nearest coastal areas, such as hedgehogs (Erinaceidae), hares (Leporidae), gerbils (Muridae, Gerbillinae), jerboas (Dipodidae), gundis (Ctenodactylidae), and ground squirrels (Sciuridae, Xerini), remains inexplicable. The extant non-flying terrestrial mammalian fauna on the Red Sea islands appears to be essentially characterised by species that are somehow connected with human subsistence (e.g., gazelles) or with voluntary (e.g., the mongoose) or involuntary (e.g., shrews and murids) introduction.

\section{Anthropochorous fauna?}

Humans have exploited the natural resources of the Red Sea since prehistory; indeed. archaeological evidence indicates that this basin has attracted human settlement since very remote times. Rather than acting as a barrier, it has been an important centre of cultural and population dispersal between Africa and Arabia. In fact, during the sea level lowstand, the Bab el Mandeb strait shrunk into a narrow, shallow channel, aiding human migration even without the need for seafaring vessels (Bailey et al., 2007). The first use of seafood dates to the Middle Palaeolithic, followed in Neolithic times by the cultural diffusion of pre-pottery elements in the northern Arabian areas (Horton, 1987). Archaeological research has revealed approximately 1000 sites, mostly shell mounds formed during the past 6000 years, in the Farasan archipelago alone (Bailey et al., 2007).

The Red Sea has been a trade route from the earliest recorded history. More than 5000 years ago, rafts or simple boats ventured forth upon its waters to bring obsidian - a black volcanic glass that yields sharp blades - from the Arabian Peninsula to Egypt, where it has been found in pre-dynastic archaeological sites. Over 3500 years ago, Egypt's pharaohs sent fleets into the Red Sea to visit copper and turquoise mines in the Sinai peninsula and to sail much farther south, probably through the Bab el Mandeb, to the fabled Land of Punt (see Kitchen, 1993) (Fig. 20). Millennia later, Roman ships regularly left ports, such as Berenike, bound for India (Ingrams, 1966; see also André-Salvini et al., 2010). In this sense, the most ancient and vivid historical account showing the importance of this trade route is the Periplus of the Erythraean Sea (Periplus Maris Erythraei), dating to $70 \mathrm{AD}$. Indian and Chinese seamen also took advantage of the northern monsoon in spring to cross the Gulf of Aden and then sail on to the Red Sea (Debelius, 1998). Not only was the Red Sea the preferential route for trade between India, the Near East, the Mediterranean and Europe, but its islands were also centres for the production of rare and precious goods, such as peridotites from Zabargad (Bonatti et al., 1983), pearls from Dungunâb, north of Sawākin, and from the Dahlak Archipelago, but also ambergris, excreted by the sperm whale, Physeter macrocephalus L., 1758, along the beaches of the Farasan archipelago (Tuchscherer, 2004). The Turks began sailing the western Indian Ocean in the $16^{\text {th }}$ century, and the Ottoman empire was the largest market for goods imported from India and the Moluccas, spreading them throughout the Muslim world. As the global economy strengthened, Arabian merchants exchanged precious coffee for imported Chinese porcelain, fabrics and spices brought by Dutch, English and Indian ships to Mocha. By linking the Red Sea with the Mediterranean, the opening of the Suez canal in 1869 finally allowed ships to travel between Europe and Asia without circumnavigating Africa, permanently altering the times and means of world maritime trade (see Galil, 2006). 


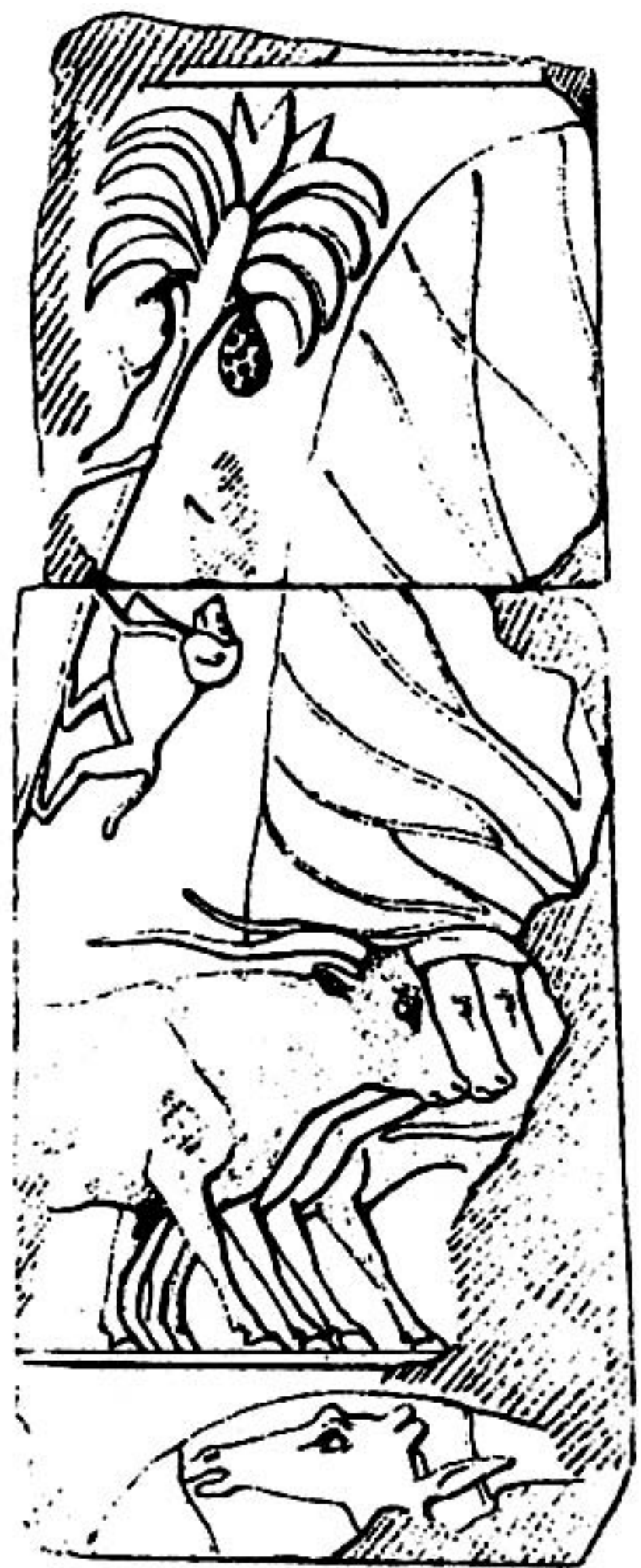

Fig. 20 - Fragment of decoration on a memorial temple to the Egyptian queen Hatshepsut $\left(15^{\text {th }}\right.$ century BC) of the $18^{\text {th }}$ Dynasty (Deir el-Bahari, Upper Egypt). It shows a baboon climbing a doum palm, Hyphaene thebaica (L.) Mart., 1838; a herd of long-horn cattle; and the head of a sub-adult giraffe, Giraffa camelopardalis L., 1758, from the mythical Land of Punt.
All this commercial trade and human movement must have had profound repercussions on the natural resources, which were already depleted by poor rainfall and an aridity that had been increasing since ancient times, especially in the southern- and western-most territories of the Red Sea. New ecological equilibria caused significant alterations in the natural distribution of several biological elements, but also the extinction of many others. Allochthonous vertebrates also began to be introduced - both deliberately and involuntarily - by man to the islands (Fig. 21). Although, for example, the earliest literary evidence of the occurrence of gazelles on the Red Sea islands goes back only to Ottoman times (Bruce of Kinnaird, 1790; Annesley Mountnorris, 1811; Rüppell, 1838; Heuglin, 1861; Benardelli, 2004; Tuchscherer, 2004), different species of these ungulates must have been introduced since very early times to the most inhospitable islets along the ancient routes across the Red Sea to ensure a supply of fresh meat. Gazelles are, in fact, the medium-sized mammalian species best adapted to the particular environmental conditions of the small and barren islands of this sea. On the islands, the ungulates, released by man in a free-ranging state, could be easily hunted for meat (Masseti, 2010). Moreover, islands are natural enclosures that allow the ungulates to derive their food supply directly from the carrying capacity of the environment, and this could have been a simple way to solve management problems (Masseti,

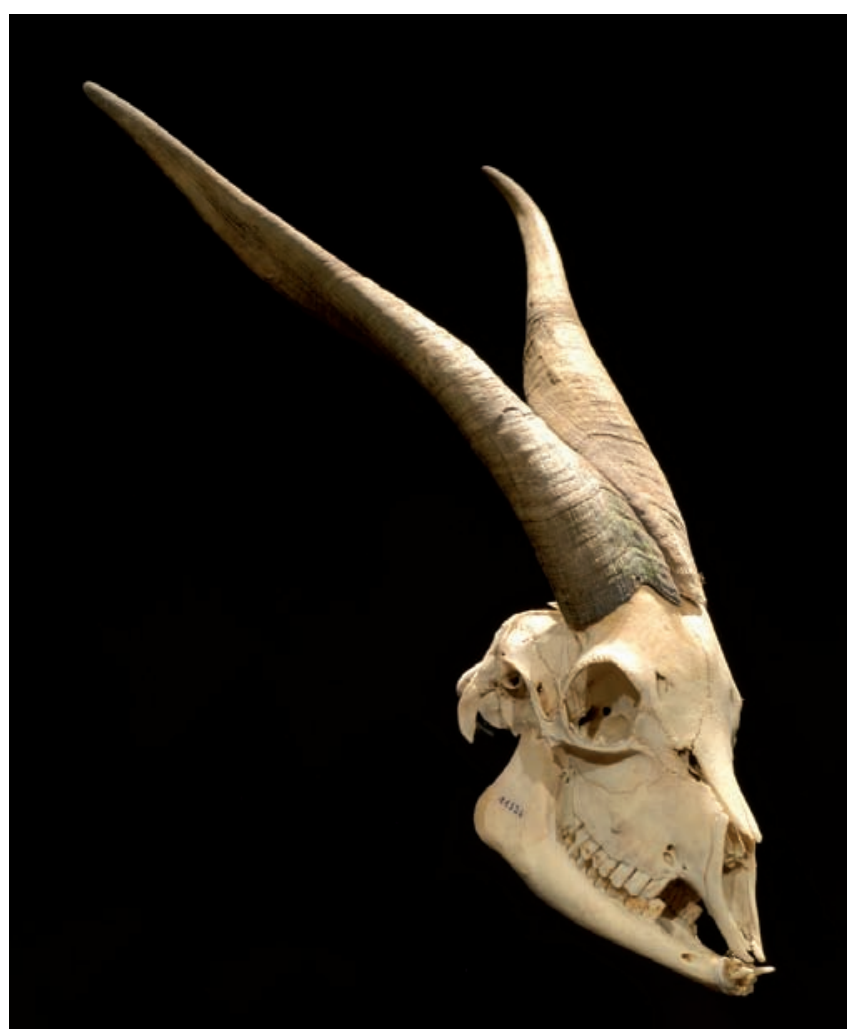

Fig. 21 - Skull of an adult male domestic goat collected on the island of Dumsuq (Farasan archipelago, Saudi Arabia) in 1984. It is evidence of the deliberate introduction of mammals by man to the Red Sea islands. It is another specimen of the Somali ethnic group, but in this case a primitive type, with straight, involute horns (photo by Saulo Bambi, courtesy of the Museo di Storia Naturale dell'Universita di Firenze, Sezione di Zoologia "La Specola"). 
1998; cf. Masseti \& Zava, 2002). This was apparently the only way to exploit marginal territories that were, otherwise, generally unattractive economically for humans (cf. Masseti, 2009c, 2012). Whatever happened in the past, the gazelles of Dahlak Kebir island are not hunted today by the local people; rather, they are protected for religious reasons (Hagos Yohannes, pers. comm.). Indeed, gazelles might have had a long and prominent history in northeastern African cultures, such as Ancient Egypt, where $N$. soemmerringii was associated with Anuket, goddess of the River Nile and of water in the Nubian (Sudanese) tradition. Anuket herself was sometimes represented as a gazelle (Strandberg, 2009; Chiozzi et al., 2014).

Excluding Sawākin and Massawa - which have been connected to the mainland by causeways since the $19^{\text {th }}$ century and have been frequented by a large human population - the non-volant mammals dispersed on the Red Sea islands include only a dozen taxa (Tab. 1). The hypothesis that all these species might have colonised the islands through human mediation is supported by the specific homogeneity of the different insular faunal communities. The exclusive dispersal on the islands of a very limited number of continental species is an undeniable fact. Noteworthy is that, of all the species that could potentially survive on the islands (e.g., gerbils and jerboas), only anthropocorous species (shrews, murids, mongooses and gazelles) are present today. However, the possibility that some species may have reached the islands without human intervention, possibly during sea level lowstands and/or through the so-called sweepstake routes, cannot be ruled out. The fox reported by Heuglin (1861) and Fitzinger (1866) from Debir (Er Rih) may have reached the island by walking across the mudflats during low tide or by swimming. The presence of humans with drinking water tanks and of commensal rodents may have allowed the survival of the fox, at least for a limited span of time. Natural colonisation from the mainland by a pair of golden jackals, Canis aureus L., 1758, occurred in 2004 on the island of Umm al-Gorm, Iran, but the local wildlife authorities soon eradicated them (Behrouzi-Rad, 2013).

\section{CONCLUSIONS}

The absence of endemic mammalian species from the Red Sea islands is so far attested by the lack of fossil and sub-fossil findings. However, very little research has been carried out on these territories compared with that conducted on the islands in the Mediterranean Sea. We suspect that islands such as Howakil and Baka in the Howakil Bay of Eritrea, which have never been explored, may disclose unexpected findings. Furthermore, a significant number of complete specimens of Crocidura from Isratu Island in the Dahlak archipelago should be investigated to establish the taxonomic status of this taxon.

The depth of the sea along the coast in the southern portion of the Red Sea, which has always been fairly shallow (today max. $-130 \mathrm{~m}$ ), together with the vertical movements of the underlying salt domes of Miocene origin, created a great number of islands, mostly made of coral rocks. The youngest islands were formed 110,000-140,000 years ago, when the sea level was the same as it is today
(Braithwaite, 1987). In the light of this, we cannot exclude that these territories were originally unsuitable for colonisation by non-volant vertebrates. Furthermore, during the Last Glacial Maximum, the negative water balance of the basin - caused by an elevated evaporation rate not compensated by an equivalent influx of water - increased the salinity of the Red Sea, creating conditions similar to those present nowadays in the Dead Sea (Braithwaite, 1987) that could have hampered the colonisation of the islands by non-flying terrestrial vertebrates. With the end of the last glacial period, about 15,000 years ago, the sea level gradually rose, reaching its present level around 7000-5000 years ago and shaping the Red Sea and its islands as we see them today. The recent formation of the islands perhaps explains the limited insular endemicity of non-flying terrestrial vertebrates (De Marchi et al., 2009). The recent origin of the islands together with their short distance from the nearest mainland, the relatively shallow depth of the surrounding seafloor, the lack of permanent fresh water bodies, and the sparse vegetation on many of them may have prevented the endemisation of mammals.

\section{Acknowledgements}

Among the many friends and colleagues who helped us as we were preparing this paper, we would like to express our appreciation and gratitude in particular to Paolo Agnelli and Saulo Bambi, Natural History Museum of the University of Florence, Zoological Section; Massa'a al Jumaily and Abdul Karim Nasher, University of Sana'a; Giovanni Amori, CNR - Institute of Ecosystem Studies, Rome; Petr Benda, Department of Zoology, National Museum (Natural History), Praha; Giuliano Doria, Museo Civico di Storia Naturale "Giacomo Doria", Genova; Katrin Krohmann, Senckenberg Forschungsinstitut Mammalogie, Frankfurt/Main; Reiner Hutterer, Zoologisches Forschnungsmuseum Alexander König, Bonn; Kamal M. Ibrahim, Southern Illinois University, Carbondale; Benedetto Lanza, Department of Biology of the University of Florence; Iyad A. Nader, Zoological Society of London/ King Khalid Wildlife Research Centre/National Commission for Wildlife Conservation and Development; Armando Nappi, Associazione Vivara Amici delle Piccole Isole, Napoli; Eike Neubert, Naturhistorisches Museum Bern; Syed Rafatullah, King Saud University, Riyhad; Eileen Westwig, American Museum of Natural History, New York; Torsten Wronski, Zoological Society of London, Conservation Programs, London, and Faculty of Veterinary Medicine, Umutara Polytechnic, Nyagatare, Rwanda; Futsum Hagos and the late Hagos Yohannes, Forestry and Wildlife Authority of Eritrea; and Frank E. Zachos, Naturhistorisches Museum Wien, Vienna. Special thanks are due to the late Derek Yalden, University of Manchester, for his help in the taxonomic identification of the mouse of Dahret, and to Nora Lange and Frieder Mayer, Museum für Naturkunde Leibniz Institut for Research on Evolution and Biodiversity at the Humboldt University Berlin, for having set at our disposal the photograph of the unique specimen of Gazella arabica still existing. Finally, we would greatly like to thank an anonymous reviewer for comments and help, which allowed us to greatly improve the original manuscript. 


\section{REFERENCES}

Abu Baker M.A., Al Omari K., Qarqaz M., Khaled Y., Yousef M. \& Amr Z.S., 2004 - On the current status and distribution of Blanford'fox, Vulpes cana Blanford, 1877, in Jordan (Mammalia: Carnivora: Canidae). Turkish Journal of Zoology, 28: 1-6.

Alcover J.T., Campillo X., Macias M. \& Sans A., 1998 Mammal species of the world: additional data on insular mammals. American Museum Novitates, 3248: $1-29$.

Al-Jumaily M.M., 1998 - Review of the mammals of the Republic of Yemen. Fauna of Saudi Arabia, 17: 477502.

Al-Saghier O., 2000 - Complete Report on the Bird Fauna of Socotra Archipelago. BirdLife International and Environmental Protection Council, UNDP/GEF/ UNOPS and Socotra Biodiversity Project.

Anderson J. \& de Winton W.E., 1902 - Zoology of Egypt. Mammalia. Hugh Rees Pub., London.

Anderson J., Abraha S. \& Berhane D., 2013 - Birdwatching in Eritrea. Dahlak Islands. <http://ibis.atwebpages. com/birdwatching in eritrea/dahlak.htm> (retrieved on $9^{\text {th }}$ February 2015 ).

André-Salvini B., Demange F., Juvin C. \& Cotty M., 2010Routes d'Arabie. Archaéologie et histoire du Royame d'Arabie Saoudite. Somogy Editions d'Art and Louvre editions, Paris.

Annesley Mountnorris G. [Viscount Valencia], 1811 Voyages and travels to India, Ceylon, the Red Sea, Abyssinia and Egypt, in the years 1802, 1803, 1804, 1805, and 1806. Vol. II. India, Read Sea, Abyssinia. F., $C$., and J. Rivington, London.

Atkinson I.A.E., 1985 - The spread of commensal species of Rattus to oceanic islands and their effects on island avifaunas. In: Conservation of island birds: case studies for the management of threatened island species. Moors P.J. (ed.). International Council for Bird Preservation, Cambridge: $35-81$

Azzaroli A., 1977 - Considerazioni sui mammiferi fossili delle isole mediterranee. Bollettino di Zoologia, 44: 201-211.

Bailey G., Al Sharekh A., Flemming N., Lambeck K., Momber G., Sinclair A. \& Vita-Finzi C., 2007 - Coastal prehistory in the southern Red Sea basin, underwater archaeology, and the Farasan islands. Proceedings of the Seminar for Arabian Studies, 37: 1-16.

Bark Jones R., 1946 - An account of a visit to the Brothers (Jebel Teir) islands in the Gulf of Aden. The Ibis, 88: 228-232.

Bärmann E.V., Börner S., Erpenbeck D., Rössner G.E., Hebel C. \& Wörheide G., 2013 - The curious case of Gazella arabica. Mammalian Biology, 78: 220-225.

Bärmann E.V., Gentry A.W. \& Gentry A., 2014 - Case 3660 Antilope arabica Lichtenstein, 1827 (currently Gazella arabica; Mammalia, Ruminantia): proposed conservation of part of the lectotype designated by Neumann (1906). Bulletin of Zoological Nomenclature, 71 (2): 88-94.

Baschieri F., 1954 - Appendice. In: Dahlak. Con la Spedizione Nazionale Subacquea in Mar Rosso. Roghi G. \& Baschieri F. (eds.). Garzanti, Milano: 229-276.
Baschieri Salvadori F.B., 1954 - Spedizione subacquea italiana: note biologiche sugli uccelli delle Isole Dahlak. Rivista Italiana di Ornitologia, 24: 98-124.

Bath-Sheba A., 1932 - Die Muriden von Palästina und Syrien. Zeitschrift für Säugetierkunde, 11: 161-240.

Behrouzi-Rad B., 2013 - Census and Phenology of Breeding waterbirds on the Islands of Khan, Tahmadon, Om-Al-Gorm and Nakhiloo in the Persian Gulf, Iran. International Journal of Marine Science, 3: 193-200.

Benardelli M., 2004 - La storia del paradiso: le Dahlak. Affari Sociali Internazionali, 32: 139-152.

Blanford W.T., 1870 - Observations on the Geology and Zoology of Abyssinia made during the progress of the British Expedition in that country in 1867-69. Macmillan, London.

Bolton M., 1973 - Notes on the current status and distribution of some large mammals in Ethiopia (excluding Eritrea). Mammalia, 37 (4): 562-586.

Bonatti E., Clocchiatti R., Colantoni P., Gelmini R., Marinelli G., Ottonello G., Santacroce R., Taviani M., Abdel-Meguid A.A., Assaf H.S. \& El Tahir M.A., 1983 - Zabargad (St. John's) Island: an uplifted fragment of sub-Red Sea lithosphere. Journal of the Geological Society, 140: 677-690.

Borkin L.J. \& Cherlin V.A., 1995 - On the validity of the name Echis coloratus and the type locality of Echis megalocephalus. Zoologichesky Zhurnal, 74 (9): 134136. In Russian.

Bousses P. \& Reale D. 1996 - Syndrome d'insularité dans une population récente de mouflons (Ovis musimon) des îles Kerguelen. Vie Milieu, 46: 285-290.

Braithwaite C.J.R., 1987 - Geology and paleongeography of the Red Sea Region. In: Key environments. Red Sea. Edwards A.J. \& Head S.M. (eds.). Pergamon Press, Oxford (UK): 22-44.

Brehm A.E., 1863 - Ergebnisse einer Reise nach Habesch. O. Meissner, Hamburg.

Bruce of Kinnaird J., 1790 - Travels to Discover the Source of the Nile, in the years $1768,1769,1770$, 1771, 1772 and 1773. J. Ruthen, Edinburgh.

Cabrera A., 1910 - On two new Carnivora from north-east Africa. The Annals and Magazines of Natural History, ser. 8, 6: 461-465.

Casson L., 1989 - The Periplus Maris Erythraei. Princeton University Press, Guildford.

Cherlin V.A., 1990 - Taxonomic revision of the snake genus Echis (Viperidae). II. An analysis of taxonomy and description of new forms. In: Reptiles of mountain and arid territories: systematics and distribution. Borkin L.J. (ed.). Proceedings of the Zoological Institute, Academy of Sciences of the USSR, Leningrad, 207: 193-223. [in Russian, with English abstract].

Chiozzi G., Bardelli G., Ricci M., De Marchi G. \& Cardini A., 2014a - Just another island dwarf? Phenotypic distinctiveness in the poorly known Soemmerring's Gazelle, Nanger soemmerringii (Cetartiodactyla: Bovidae), of Dahlak Kebir Island. Biological Journal of the Linnean Society, 111: 603-620.

Chiozzi G., Bardelli G., Ricci M., De Marchi G. \& Cardini A., 2014b - Le piccole gazzelle insulari di Dahlak Kebir. Natura, 104 (1): 7-15. 
Clapham C.S., 1964 - The birds of the Dahlac Archipelago. Ibis, 106: 376-388.

Cloudsley-Thompson J.L., 1968 - The Merkhyat Jebels: a desert community. In: Desert biology. Brown J.W. (ed.). Academic Press, New York: 1-20.

Clutton-Brock J., 1981 - Domesticated animals from early times. Heinemann/British Museum (Natural History), London.

Clutton-Brock J., Corbet G.B. \& Hills M., 1976 - A review of the family Canidae, with a classification by numerical methods. Bulletin of the British Museum (Natural History), Zoology, 29:119-199.

Coetze C.G., 1967 - Carnivora. In: Preliminary identification manual for African mammals. Meester J.A.J. (ed.). Smithsonian Inst., Washington D.C., 7: 1-70.

Coleman R.G., 1993 - Geological evolution of the Red Sea. Oxford Monographs on Geology and Geophysics. Oxford University Press, New York.

Corbet G.B., 1978 - The mammals of the Palaearctic Region: a taxonomic review. British Museum (Natural History)/Cornell University Press, London and Ithaca.

Corbet G.B. \& Hill J.E., 1992 - A world list of mammalian species. Natural History Museum Publications/ Oxford University Press, Oxford and New York.

Cretzschmar J., 1830 - Säugetiere. In: Atlas zu der Reise in Nördlichen Afrika. Rüppel E. (ed.). Zoologie, Frankfurt am M., Abth. 1. Part. 1.

Cunningham P.L. \& Wronski T., 2011 - Twenty years of monitoring of the Vulnerable Farasan gazelle Gazella gazella farasani on the Farasan Islands, Saudi Arabia: an overview. Oryx, 45 (1): 50-55.

Cuthbert R. \& Hilton G., 2004 - Introduced house mice Mus musculus: a significant predator of threatened and endemic birds on Gough Island, South Atlantic Ocean? Biological Conservation, 117: 483-489.

Cuzin M. \& Lenain M. 2004 - Rüppell's fox Vulpes rueppellii (Schinz, 1825). In: Status Survey and Conservation Action Plan Canids: Foxes, Wolves, Jackals and Dogs. Sillero-Zubiri C., Hoffmann M. \& Macdonald D.W. (eds.). IUCN/SSC Canid Specialist Group. IUCN, Gland, Switzerland and Cambridge, UK: 201-205.

De Beaux O., 1923 - Di alcuni chirotteri africani del Museo Civico di Milano. Atti della Società Italiana di Scienze Naturali e del Museo Civico di Storia Naturale di Milano, 62: 91-101.

De Beaux O., 1928 - Risultati zoologici della missione inviata dalla R. Società Geografica Italiana per l'esplorazione dell'oasi di Giarabub (19261927). Annali del Museo Civico di Storia Naturale "Giacomo Doria", 53: 39-76.

De Beaux O., 1930-31 - Spedizione del Barone Raimondo Franchetti in Dancalia. Mammiferi. Annali del Museo Civico di Storia Naturale "Giacomo Doria", 60: 183-217.

Debelius H., 1998 - Red Sea reef guide. Egypt, Israel, Jordan, Sudan, Saudi Arabia, Yemen, Arabian Peninsula (Oman, UAE, Bahrain). IKAN Unterwasserarchiv, Frankfurt.

Delibes de Castro M., de Aizpuro J. \& León Jiménez F., 1990 - Los venados de nuestras sierras. RAYCAR, S.A. Impresores, Madrid.
Del Prato A., 1891 - I vertebrati raccolti nela colonia Eritrea dal Capitano Vittorio Bòttego. Boll. Sez. fiorentina Soc. afr, ital, 7: 19-77.

De Marchi G., 2002 - Le isole Dahlak. Natura, 92 (1): 18.

De Marchi G., 2004 - Dahlak. Perle di corallo del Mar Rosso. Museo di Storia Naturale di Milano/Libreria Cortina, Milano.

De Marchi G., Chiozzi G. \& Semere D., 2009 - Wings over the Red Sea. The birds of the Eritrean islands. Natura, 99 (2): 1-128.

De Marchi G., Chiozzi G., Semere D., Galeotti P., Boncompagni E. \& Fasola M., 2006 - Nesting, overwintering, and conservation of the Crab Plover Dromas ardeola in central Eritrea. Ibis, 148 (4): 753-564.

De Marchi G., Montesanto G. \& Traverso G., 2013 - Isole Dahlak. Un arcipelago del Mar Rosso eritreo. Erga edizioni, Genova.

Dollman J.G., 1927 - A new race of Arabian Gazelle. Proceedings of the Zoological Society of London, LXVI: 1005.

Dorst J. \& Dandelot P., 1969 - A field guide to the larger mammals of Africa. Collins, London (UK).

Edwards F.J. 1987 - Climate and Oceanography. In: Key environments. Red Sea. Edwards A.J. \& Head S.M. (eds.). Pergamon Press, Oxford.

Egan D., 2007 - Snakes of Arabia. Motivate Publishing, Dubai.

Ehrenberg C.G., 1827 - Vorläufige Bemerkungen über eine, noch unbekannte grössere Insel im rothen Meere, von den Insularen Farsan genannt. Hertha, Zeischrift für Erd-, Völker- und Staatenkunde, 9: 312-319.

Evans M.I. (ed.), 1994 - Important bird areas in the Middle East. BirdLife International, Cambridge.

Evans P.G.H., 1987 - Sea birds of the Red Sea. In: Key Environments: Red Sea. Edwards A.J. \& Head S.M. (eds.). Pergamon Press, Oxford.

Felemban H.M., 1995 - Trapping of spring migrants on Qummah Island, Farasan archipelago in the Red Sea. OSME Bulletin, 35: 1-13.

Fisher P.R., 2001 - Ecology and behaviour of osprey Pandion haliaetus on the Farasan Islands, Red Sea, Saudi Arabia. Manchester Metropolitan University, Manchester.

Flamand J.B.R., Thoulless C.R., Tatwany H. \& Asmode J.-F., 1988 - Status of the gazelles of the Farasan Islands, Saudi Arabia. Mammalia, 52: 608-610.

Funaioli U., 1971 - Guida breve dei mammiferi della Somalia. Istituto Agronomico per l'Oltremare, Roma.

Galil B.S., 2006 - The Suez Canal. The Marine Caravan. The Suez Canal and the Erythrean Invasion. In: Bridging Divides. Maritime Canals as Invasion Corridors. Gollash S., Galil B.S. \& Cohen A.N. (eds.). Springer, Dordrecht (The Netherlands).

Gasperetti J., 1988 - Snakes of Arabia. Fauna of Saudi Arabia, 9: 169-450.

Gasperetti J., Harrison D.L. \& Büttiker W., 1985 - The Carnivora of Arabia. Fauna of Saudi Arabia, 7: 397-461.

Gass I.G., Mallick D.I.J. \& Cox K.G., 1973 - Volcanic islands of the Red Sea. Journal of the Geological Society, 129 (3): 275-309. 
Ginsberg J.R. \& Macdonald D.W., 1990 - Foxes, wolves, jackals and dogs: an action plan for the conservation of Canids. IUCN, Gland.

Gippoliti S., 2010 - La Giungla di Villa Borghese. I cento anni del Giardino Zoologico di Roma. Edizioni Belvedere, Latina.

Gippoliti S., 2013 - Luigi Fossati e le conoscenze mammalogiche eritree degli italiani. Natura, 103 (1): 123134.

Gladstone W., 2000 - The ecological and social basis for management of a Red Sea marine-protected area. Ocean \& Coastal Management, 4: 1015-1032.

Gladstone W., Facey R. \& Hariri K., 2006 - State of the Marine Environment. Report for the Red Sea and Gulf of Aden: 2006. PERSGA (The Regional Organization for the Conservation of the Environment of the Red Sea and Gulf of Aden), Jeddah.

Google Earth 7.1. 2014. El Rih Island. 18'58.18”N, $38^{\circ} 28^{\prime} 4.87^{\prime}$ 'E. Downloaded on 11/01/2014.

Groves C.P. 1983 - Notes on gazelles IV. The Arabian gazelles collected by Hemprich and Ehrenberg. Zeitschrift für Säugetierkunde, 48: 371-381.

Groves C.P., 1985 - An introduction to the gazelles. Chinkara, 1: 4-10.

Groves C.P., 1997 - The taxonomy of Arabian gazelles. In: The gazelles of Arabia. Habibi K., Abuzinada A.H. \& Nader I.A. (eds.). National Commission for Wildlife Conservation and Development. Riyadh (Saudi Arabia), 29.

Grubb P., 2005 - Order Artiodactyla. In: Mammal species of the world. A taxonomic and geographic reference. Wilson D.E. \& Reeder D.-A.M. (eds.). Third Edition. The Johns Hopkins University Press, Baltimore, .1

Gübelin E., 1981 - Zabargad: the ancient peridot island in the Red Sea. Gems \& gemology, Spring 1981: 17 (1): 2-8.

Haltenorth T. \& Diller H., 1977 - Säugetiere Afrikas und Madagaskars. BLV Verlagsgesellschaft $m b H$, München.

Harrison D.L., 1965 - Remarks on some Trident Leafnosed bats (genus Asellia Gray, 1838) obtained by the Israel south Red Sea Expedition, 1962, Rep. No. 5. Bulletin of the Sea Fisheries Research Station, Haifa, 38: 23-25.

Harrison D.L. 1968 - The mammals of Arabia. Volume II. Carnivora - Artiodactyla - Hyracoidea. Ernest Benn Ltd., London.

Harrison D.L., 1972 - The mammals of Arabia. Volume III. Lagomorpha - Rodentia. Ernest Benn Ltd., London.

Harrison D.L., 1981 - Mammals of the Arabian Gulf. George Allen \& Unwin, London.

Harrison D.L. \& Bates P.J.J., 1991 - The Mammals of Arabia. Harrison Zoological Museum, Sevenoaks (UK).

Hayman R.W. \& Hill J.E., 1971 - Order Chiroptera. In: The mammals of Africa. An identification manual. Meester J. \& Setzer H.W. (eds.). Part 2. Smithsonian Institution Press, Washington.

Hemprich F.G. \& Ehrenberg C.G., 1828 - Symbolae Physicae. Pars Zoologica I. Officine Academica, Berlin.
Heuglin T. von, 1861 - Forschungen über die Fauna des Rothen Meeres und der Somáli-Küste. Ein systematisches Verzeichnis der Säugethiere und Vögel, welche in diesen Regionen bisher beobachtet worden sind, mit Rücksicht auf ihre geographische Verbreitung in horizontaler und vertikaler Ausdehnung. Petermanns Geographische Mittheilungen, 1861: 11-32.

Heuglin T. von, 1877 - Reise in Nordost-Afrika. Schilderungen aus dem Gebiete der Beni Amer und Habab nebst zoologischen Skizzen und einem Führer für Jagdreisende. 1. George Westermann, Braunschweig.

Heuglin T. von \& Fitzinger L.J., 1866 - Systematische Übersicht der Säugethiere Nordost-Afrika's mit Einschluß der arabischen Küste, des rothen Meeres, der Somáli- und der Nilquellen-Länder, südwärts bis zum vierten Grade nördlicher Breite. Von Dr Theodor v. Heuglin. Nach brieflichen Mittheilungen und den Original-Exemplaren des Herrn Verfassers ergänzt und mit Zusätzen versehen von dem w. M. Dr Leopold Joseph Fitzinger. Sitzungsberichte der Kaiserlichen Akademie der Wissenschaften, Abt. 1. MathematischNaturwissenschaftliche Klasse 54: 537-611.

Hill M. \& Webb P., 1984 - An introduction to the wildlife of Bahrain. Ministry of Information, Bahrain.

Hillman J.C., 1993 - Trip notes (UNDP GEF Mission) Dahlak Islands. Unpublished report. Wildlife Conservation International. New York Zoological Society, New York.

Hinton H.E. \& Dunn A.M.S., 1967 - Mongooses: their natural history and behaviour. Oliver \& Boyd, London and Edinburgh/University of California Press, Berkeley.

Horton M., 1987 - The human settlement of the Red Sea. In: Key Environments: Red Sea. Edwards A.J. \& Head S.M. (eds.). Pergamon Press, Oxford (UK).

Howald G., Donlan C.J., Galván J.P., Russell J.C., Parkes J., Samaniego A., Wang Y., Veitch D., Genovesi P., Pascal M., Sauders A. \& Tershy B., 2007 - Invasive Rodent Eradication on Islands. Conservation Biology, 21: $1258-1268$.

Hutterer R., 2005 - Order Soricomorpha. In: Mammal Species of the World. A Taxonomic and Geographic Reference. Wilson D.E. \& Reeder D.M. (eds.). Third Edition. The Johns Hopkins University Press, Baltimore, 1: 220-311.

Ilani G., 1983 - Blanford's fox, Vulpes cana Blanford, 1877, a new species to Israel. Israel Journal of Zoology, 32: 150 .

Ingrams H., 1966 - Arabia and the isles. $3^{\text {rd }}$ edition. John Murray, London.

Jennings M.C., 1988 - A note on the birds of the Farasan Islands, Red Sea, Saudi Arabia. Fauna of Saudi Arabia, 9: 457-467.

Joger U., 2010 - Echis megalocephalus. In: IUCN 2013. IUCN Red List of Threatened Species. Version 2013.1. $<$ www.iucnredlist.org $>$ (retrieved on $9^{\text {th }}$ February 2015).

Karami M. \& Groves C. P., 1993 - A mammal species new for Iran: Gazella gazella Pallas, 1766 (Artiodactyla, Bovidae). Journal of Sciences of the Islamic Republic of Iran, 4: 81-89. 
Kauhala K., 1996 - Introduced carnivores in Europe with special reference to central and northern Europe. Wildlife Biology, 2 (3): 197-204.

Kingdon J., 1982 - East African Mammals: an atlas of evolution in Africa. Volume IIID bovids. The University of Chicago Press, Chicago.

Kingdon J., 1990 - Arabian mammals. A natural history. Academic Press, London/New York/Tokyo/ Sydney.

Kingdon J., 2004 - The Kingdon Pocket Guide to African mammals. $A \& C$ Black, London.

Kitchen K.A., 1993 - The land of Punt. In: The archaeology of Africa. Food, metals and towns. Shaw T., Siclair P., Andah B. \& Okpoko A. (eds.). Routledge, London and New York.

Klemetti E., 2011 - Potential eruption off the coast of Yemen. Wired Science Blog-Eruptions. <http://www. wired.com/2011/12/potential-eruption-off-the-coastof-yemen/ $>$ (Retrieved $9^{\text {th }}$ February 2015).

Kock D., 1980 - Wimperspitzmaus an der afrikanischen Roten Meer-Küste (Mammalia: Insectivora: Soricidae). Senckenbergiana Biologica, 60 (3/4): 137139.

Kock D. \& Stanley W.T., 2009 - Mammals of Mafia Island, Tanzania. Mammalia, 73: 339-352.

Lackman-Acrenaz I., 1998 - Le commensalisme du babouin hamadryas (Papio hamadryas hamadryas) en Arabie Saoudite. PhD dissertation. Museum National d'Histoire Naturelle, Paris.

Largen M.J., 1997 - An annotated checklist of the amphibians and reptiles of Eritrea, with keys for their identification. Tropical Zoology, 10: 63-115.

Largen M.J. \& Spawls S., 2010 - Amphibians and Reptiles of Ethiopia and Eritrea. Edition Chimaira, Frankfurt.

Largen M.J., Kock D. \& Yalden D.W., 1974 - Catalogue of the mammals of Ethiopia. 1. Chiroptera. Monitore Zoologico Italiano, Suppl. 5: 221-298.

Laurent A. \& Laurent D., 2002 - Djibouti au rythme du vivant. Les mammifères d'hier à aujourdhui pour demain. Editions Beira CFP, Toulouse.

Leche W., 1902 - Zur Entwicklungsgeschichte des Zahnsystems der Säugetiere, zugleich ein Beitrag zur Stammesgeschichte dieser Thiergruppe. II. Phylogenie. 1. Die Familie der Erinaceide. Zoologica - Original Abhandlungen dem gesamtgebiete der Zoologie. Erwin Nagele, Stuttgart.

Lerp H., Wronski T., Butynski T.M. \& Plath M., 2013 Speciation of Arabian gazelles. In: Speciation: Natural Processes, Genetics and Biodiversity. Michalak P. (ed.). Nova Science, Hauppauge.

Lever C., 1985 - Naturalized mammals of the world. Longman, London/New York.

Leviton A. E., Anderson S.C., Adler K. \& Minton S.A., 1992 - Handbook to Middle East Amphibians and Reptiles. Society for the Study of Amphibians and Reptiles, Oxford, Ohio, Contributions to Herpetology, 8: $1-252$.

Lewinsohn C. \& Fishelson L., 1967 - The Second Israel South Red Sea Expedition, 1965. Israel Journal of Zoology, 6 (2): 59-68.
Lichtenstein H., 1827-1834 - Darstellung neuer oder wenig bekannter Säugethiere in Abbildungen und Beschreibungen von Fünf und Sechzig Arten. C.G. Lüderitz, Berlin.

Lipkin Y., 1987 - Marine vegetation of the Museri and Entedebir islands (Dahlak archipelago, Red Sea). Israel Journal of Botany, 36 (2): 87-99.

Lister A.M., 1989 - Rapid dwarfing of red deer on Jersey in the Last Interglacial. Nature, 342: 539-542.

Lister A.M., 1993 - Mammoths in miniature. Nature, 362: 288-289.

Lister AM., 1996 - Dwarfing of island elephants and deer: processes in relation to time and isolation. Symposium of the Zoological Society of London, 69: 277292.

Long J.L., 2003 - Introduced mammals of the world. Their history, distribution and influence. CABI Publishing, Oxon.

Lydekker R., 1896 - A handbook to the Carnivora. Part I. Cats, civets, and mongooses. Edward Lloyd Ltd., London.

Lydekker R., 1914 - Catalogue of the ungulate mammals in the British Museum (Natural History). Vol. III. Artiodactyla, Families Bovidae, Subfamilies Aepycerontinawe to Tragephalinae, Antilocapridae, and Giraffidae. Longmans, Green \& Co, B. Quaritch, Dulau \& Co., London, British Museum (Natural History), London.

Macfadyen W.A., 1930 - The Geology of the Farasan Islands, Gizan and Kamaran Island, Red Sea. The Geological Magazine, 67: 310-315.

Madon K.S. \& Gundevia E.N. (eds.), 1952 - A Guide to Zanzibar. Government Printer, Zanzibar.

Mallon D.P. \& Hoffmann M. , 2008 - Gazella arabica. In: The IUCN Red List of Threatened Species, 2008. $<$ http://dx.doi.org/10.2305/IUCN.UK.2008.RLTS. T8981A12946441.en> (Retrieved 18 October 2015).

Mallon D.P. \& Kingswood, S.C., 2001 - Antelopes. Part 4: North Africa, the Middle East, and Asia. Global Survey and Regional Action Plans. SSC Antelope Specialist Group. IUCN, Gland and Cambridge.

Martin J., Thibault J. \& Bretagnolle V., 2000 - Black rats, island characteristics and colonial nesting birds in the Mediterranean: consequences of an ancient introduction. Conservation Biology, 14: 1452-1466.

Masseti M., 1998 - Holocene endemic and anthropochorous wild mammals of the Mediterranean islands. Anthropozoologica, 28: 3-20.

Masseti M. 2009a - Mammals of the Mediterranean islands: homogenisation and the loss of biodiversity. Mammalia, 73: 169-202.

Masseti M., 2009b - Carnivores of Syria. ZooKeys, 31: 229-252.

Masseti M., 2009c - The wild goats, Capra aegagrus Erxleben, 1777, of the Mediterranean Sea and the Eastern Atlantic Ocean islands. Mammal Review, 39: 141-157.

Masseti M., 2010a - The mammals of the Farasan archipelago, Saudi Arabia. Turkish Journal of Zoology, 34: 359-365. 
Masseti M., 2010b - Islands as natural enclosures II: porcupines and gazelles. In: ICAZ 2010. $11^{\text {th }}$ International Conference of Archaeozoology. Vigne J.-D., PatouMathis M. \& Lefèvre C. (eds.). Muséum National d'Histoire Naturelle, Paris: 184-185.

Masseti M., 2012 - Atlas of terrestrial mammals of the Ionian and Aegean islands. De Gruyter, Berlin.

Masseti M., 2014 - Herpetological enigmas from the Arabian seas, with particular reference to the Sarso island racer, Platyceps insularis Mertens, 1965 (Farasan archipelago, Saudi Arabia). In: Scripta Herpetologica. Studies on Amphibians and Reptiles in honour of Benedetto Lanza. Capula M. \& Corti C. (eds.). Societas Herpetologica Italica/Edizioni Belvedere, Latina: 99-116.

Masseti M. \& Bruner E., 2009 - The primates of the western Palaearctic: a biogeographical, historical, and archaeozoological review. JASS Journal of Anthropological Sciences, 87: 33-91.

Masseti M. \& Mazza P., 1996 - Is there any paleontological "treatment" for the "insular syndrome"? Vie Milieu, 46 (3/4): 355-363.

Masseti, M. \& Zava B., 2002 - The red deer of Lampedusa (Pelagian islands, Italy): literary references and osteological evidence. Archives of Natural History, 29: 51-66.

Maza E., Feldman A., Fishelson L. \& Meiri S., 2015 Platyceps largeni (Schätti, 2001) - sixth specimen and a distribution extension. CheckList, 11 (1): 1517.

Mazza P., 2007 - Understanding elephant dwarfism on Sicily (Italy) and Flores (Indonesia): still a long way to go. Human Evolution, 22 (1-2): 89-95.

McDiarmid R.W., Campbell J.A. \& Touré T., 1999 Snake Species of the World: A Taxonomic and Geographic Reference. Herpetologists' League, Washington DC, 1.

Mendelssohn H. \& Yom-Tov Y., 1999 - Fauna palaestina. Mammalia of Israel. The Israel Academy of Sciences and Humanities, Jerusalem.

Merriam C.H., 1898 - New names for Spermophilus brevicaudus, Canis pallidus and Sorex cautadus Merriam. Science N.S., 8 (205): 782.

Mertens R., 1925 - Verzeichnis der Säugetier-Typen des Senckenbergischen Museums. Senckenbergiana, 7: 18-37.

Mertens R., 1965 - Eine neue Natter von einer Insel des Rotes Meeres. Senkenbergiana biologica, 46 (1): 5-9.

Nader I.A., 1990 - Checklist of the mammals of Arabia. Fauna of Saudi Arabia, 11: 329-381.

National Commission for Wildlife Conservation and Development (NCWCD), 2000 - Farasan Islands Protected Area Master Management Plan, Riyadh (Saudi Arabia).

Neumann O., 1906 - Über einige Gazellen und Kuh-Antilopen. Sitzungsberichte der Gesellschaft Naturforschender Freunde zu Berlin, 1906: 237-247.

Newton S.F., 1995 - Kingdom of Saudi Arabia. In: A Directory of Wetlands in the Middle East. Scott D.A. (ed.). IUCN, Gland and IWRB, Slimbridge: 1-51.

Oriani A. \& Castiglioni R., 2003 - Gli ungulati del Museo Civico di Storia Naturale di Milano: Perissodactyla ed Artiodactyla. Natura, 93 (1).
Osborn D.J. \& Helmy I., 1980 - The contemporary land mammals of Egypt (including Sinai). Fieldiana Zoology, 5.

Osborne P.E., 1992 - Preliminary field survey of the Houbara Bustard in Abu Dhabi, United Arab Emirates. Phase 2. Survey of potential breeding habitat in Abu Dhabi. Interim report to the Scientific Advisory Panel of the National Avian Research Center. National Avian Research Center, Abu Dhabi.

Pancucci-Papadopoulou M.A., Raitsos D.E. \& CorsiniFoka M., 2012 - Biological invasions and climatic warming: implications for south-eastern Aegean ecosystem functioning. Journal of the Marine Biological Association of the United Kingdom, 92 (4): 777-789.

Parisi B., 1917 - Catalogo dei mammiferi eritrei del Museo di Milano. Atti della Società italiana di Scienze naturali, 56: 320-330.

PERSGA/GEF, 2004 - Regional Action Plan for the Conservation of Breeding Seabirds and their Habitats in the Red Sea and Gulf of Aden. PERSGA, Jeddah.

Peters G. \& Rödel R., 1994 - Blanford's fox in Africa. Bonner zoologische Beiträge, 45 (2): 99-111.

Pilcher N.J., 2000 - Corals and human disturbance in the Red Sea and Gulf of Aden. Al-Sambouk, 12: 10-13.

Por F.D., 2009 - Tethys returns to the Mediterranean: Success and limits of tropical re-colonization. BioRisk, 3: 5-19.

Pritchard J.M., 1979 - Landform and landscape in Africa. Edward Arnold, London.

Ramusio G.B., 1563 - Delle navigazioni et viaggi. Primo volume, et Terza editione. Stamperia de Giunti, Venezia: 176-189.

Roghi G. \& Baschieri F., 1954 - Dahlak. Con la Spedizione Nazionale Subacquea in Mar Rosso. Garzanti, Milano.

Rüppell E., 1826 - Atlas zu der Reise im nördlichen Afrika. Erste Abteilung. Zoologie. Lüdwig Brönner, Frankfurt am Mein.

Rüppell E., 1835 - Neue Wirlbeltiere zu der Fauna von Abyssinien gehörig. Säugetiere. Siegmund Schmerber, Frankfurt am Mein.

Rüppell E., 1838 - Reise in Abyssinien. Vol. 1. Siegmund Schmerber, Frankfurt a. Mein.

Rüppell E., 1840 - Reise in Abyssinien. Vol. 2. Atlas mit Karten und Abb. Siegmund Schmerber, Frankfurt a. Mein.

Rüppell E., 1842 - Säugetiere aus der Ordnung der nager, beobacthet in Nord-Estlichen Afrika. Museum Senckenbergianum, 3: 99-116.

Schätti B., 2001 - A new species of Coluber (sensu lato) from the Dahlak islands, Eritrea, with a review of the herpetofauna of the archipelago. Russian Journal of Herpetology, 8 (2): 139-148.

Schoff W.H., 1912 - The Periplus of the Erythraean Sea. Travel and trade in the Indian Ocean by a merchant of the first century. Longmans, Green, and Co., New York.

Sclater P.H. \& Thomas O., 1897-1898 - The book of antelopes, III. R. H. Porter, London.

Setzer H.W., 1956 - Mammals of the Anglo-Egyptian Sudan. Proceedings of the United States National Museum, 106: 447-587. 
Shalmon B., 2004 - Mammals. In: The Red Book of the Vertebrates in Israel. Dolev A. \& Perevolotsky A. (eds). The Israel Nature and Parks Authority and the Society for the Protection of Nature in Israel, Jerusalem: 211-289.

Sheppard C., Price A. \& Roberts C., 1992 - Marine ecology of the Arabian region: patterns and processes in extreme tropical environments. Academic Press, London.

Shobrak M., Alsuhaibany A. \& Al-Segheir O., 2003 - Regional Status of Breeding Seabirds in the Red Sea and the Gulf of Aden. The Regional Organization for the Conservation of the Environment of the Red Sea and Gulf of Aden (PERSGA).

Sillero-Zubiri C., 2004 - Pale fox Vulpes pallida (Cretzschmar, 1827). In: Status Survey and Conservation Action Plan Canids: Foxes, Wolves, Jackals and Dogs. Sillero-Zubiri C., Hoffmann M. \& Macdonald D.W. (eds.). IUCN/SSC Canid Specialist Group. IUCN, Gland and Cambridge: 199-200.

Sordelli F., 1902 - Materiali per la conoscenza della fauna Eritrea, raccolti dal Dott. Paolo Magretti. Atti della Società italiana di Scienze naturali, 41: 49-99.

Strandberg A., 2009 - The gazelle in ancient Egyptian art: image and meaning. Unpublished $\mathrm{Ph} \mathrm{D}$ Thesis, Uppsala Universitet, Uppsala (Sweden). <http://uu.divaportal.org/smash/get/diva2:232265/FULLTEXT01. pdf $>$ (retrieved on $15^{\text {th }}$ February 2015).

Su-Aretz S., 1979 - Spoonbills on Tiran island. Israel Land and Nature, 4 (4): 170.

Taylor M.E., 1972 - Ichneumia albicauda. Mammalian species, 12: 1-5.

Taylor M.E., 2013 - Ichneumia albicauda White-tailed Mongoose. In: The Mammals of Africa. V. Carnivores, Pangolins, Equids and Rhinoceroses. Kingdon J. \& Hoffmann M. (eds.). Bloomsbury, London: 342-346.

Thomas O., 1900 - On the mammals obtained in Southwestern Arabia by Messrs. Percival and Dodson. Proceedings of the Zoological Society of London, 7: 95-104.

Thomas O., 1918 - Some notes on the small sand-foxes of North Africa. Annals of the Magazine of Natural History, 9: 243-245.

Thouless C., 1991 - Conservation in Saudi Arabia. Oryx, 25: $222-228$.

Thouless C.R. \& Al Bassri K., 1991 - Taxonomic status of the Farasan Island gazelle. Journal of Zoology, 223: 151-159.

Tomé C., 2003 - Les Mammifères et les Oiseaux dans l'économie des sociétés protohistoriques et historiques du golfe Arabo-Persique (III ${ }^{\mathrm{e}}$ millénaire avant J.-C. -VII ${ }^{\mathrm{e}}$ siècle après J.-C.). PhD thesis, Université AixMarseille.

Torunsky R., Ghebremariam F. \& Ibrahim K., 2007 Conservation genetics of isolated gazelle populations on the Dahlak archipelago, Red Sea. In: Abstracts V European Congress of Mammalogy. Siena, Italy. 2126 September 2007. Abstracts: oral \& poster presentations. Prigioni C. \& Sforzi A. (eds.). University of Siena/University of Pavia/University of Rome. Hystrix The Italian Journal of Mammalogy (N.S.), 2, supp. 2007: 432.
Torunsky R., Ibrahim K.M., Ghebremariam F., 2010 Conservation genetics of gazelle populations on the Dahlak archipelago. 2010 Midwest Ecology \& Evolution Conference: Poster Session. Iowa State University, Ames (Iowa) 26-28 March 2010: 38.

Towns D.R., Atkinson I.A.E. \& Daugherty C.H., 2006 Have the harmful effects of introduced rats on islands been exaggerated? Biological Invasions, 8: 863-891.

Tuchscherer M., 2004 - Îles et insularité en mer Rouge à l'époque ottomane $\left(\mathrm{XVI}^{\mathrm{e}}\right.$ - début $\mathrm{XIX}^{\mathrm{e}}$ siècle). In: Insularités ottomanes. Vatin N. \& Veinstein G. (eds.). Maisonneuve \& Larose/Institut Français d'Etudes Anatoliennes, Paris: 203-219.

Van Vuren D.H. \& Bakker V.J., 2009 - Rapid morphological change in an insular population of feral sheep. Journal of Zoology, 277: 221-231.

Vartanyan S.L., Garutt V.E. \& Sher A.V., 1993 - Holocene dwarf mammoths from Wrangel Island in the Siberian Arctic. Nature, 362: 337-340.

Wilson D.E. \& Reeder D.M. (eds.), 2005 - Mammal Species of the World. A Taxonomic and Geographic Reference. Third Edition. The Johns Hopkins University Press, Baltimore.

Wozencraft W., 2005 - Order Carnivora. In: Mammal Species of the World. A Taxonomic and Geographic Reference. Third Edition. Volume 1. Wilson DE, Reeder DM (eds.). The Johns Hopkins University Press, Baltimore (USA): 532-628.

Wranik W., 2003 - Fauna of the Socotra archipelago: field guide. With contributions by Al-Saghier O.S., Aspinall S., Porter R.F. \& Rösler H. Universität Rostock, Rostock.

Wronski T., 2013 - Population development of Arabian gazelles (Gazella arabica) on the Farasan Islands, Saudi Arabia (Mammalia: Bovidae). Zoology in the Middle East, 59 (3): 189-195.

Wronski T. \& Cunningham P., 2010 - The island gazelle: News from the largest known idmi population on the Arabian Peninsula. Gnusletter, 28 (2): 19-22.

Wronski T., Wacher T., Hammond R.L., Winney B., Hundertmark C.J., Blacket M.J., Mohammed O.B., Flores B., Omer S.A., Macasero W., Plath M., Tiedemann R. \& Bleidorn C., 2010 -Two reciprocally monophyletic mtDNA lineages elucidate the taxonomic status of Mountain gazelles (Gazella gazella). Systematics and Biodiversity, 8 (1): 119-129.

Yalden D., Largen M.J. \& Kock D., 1976 - Catalogue of the mammals of Ethiopia. 2. Insectivora and Rodentia. Monitore zoologico italiano, N.S., supplemento 8, 1: 1-118.

Yalden D., Largen M.J. \& Kock D., 1977 - Catalogue of the mammals of Ethiopia. 3. Primates. Monitore zoologico italiano, N.S., supplemento 9, 15: 1-52.

Yalden D., Largen M.J. \& Kock D., 1984 - Catalogue of the mammals of Ethiopia. 5. Artiodactyla. Monitore zoologico italiano, N.S., supplemento 19, 4: 67-221.

Yalden D.W., Largen M.J., Kock D. \& Hillman J.C., 1996 Catalogue of he mammals of Ethiopia and Eritrea. 7. Revised checklist, zoogeography and conservation. Tropical Zoology, 9: 73-164. 


\begin{abstract}
APPENDIX
Gazeteer of the Red Sea localities cited in the text. The names in the first column (in alphabetical order) are quoted from published literature and maps and coherently reported in the text of the article. The second column gives the names approved by the National Geospatial-Intelligence Agency (NGA) (http://geonames. nga.mil/namesgaz/). The third column (Geographic Feature) includes both natural and artificial characteristics of the territory. Coordinates (fourth column) and country (fifth column) are similarly referred to the same source. The islands we list as NN plus number were named according to an unpublished list of the Eritrean Ministry of Marine Resources (see: De Marchi et al., 2006).
\end{abstract}

\begin{tabular}{|c|c|c|c|c|}
\hline Name as in text & Name approved & $\begin{array}{l}\text { Geographic } \\
\text { feature }\end{array}$ & Coordinates & Country \\
\hline al Hasani & Al Ḩasān̄̄ & island & $\begin{array}{l}24^{\circ} 58^{\prime} 40^{\prime \prime} \mathrm{N} \\
037^{\circ} 05^{\prime} 01^{\prime \prime} \mathrm{E}\end{array}$ & Saudi Arabia \\
\hline al-Hanish al-Kabir & $\begin{array}{l}\text { Jazīrat al Ḩanīsh al } \\
\text { Kabīr }\end{array}$ & island & $\begin{array}{l}13^{\circ} 42^{\prime} 44^{\prime \prime} \mathrm{N} \\
042^{\circ} 43^{\prime} 32^{\prime \prime} \mathrm{E}\end{array}$ & Yemen \\
\hline Assab Bay & Bay of Aseb & bay & $\begin{array}{l}12^{\circ} 54^{\prime} 26^{\prime \prime} \mathrm{N} \\
042^{\circ} 49^{\prime} 24^{\prime \prime} \mathrm{E}\end{array}$ & Eritrea \\
\hline Bab el Mandeb & $\begin{array}{l}\text { Bāb al Mandab, Bab } \\
\text { el Mandeb }\end{array}$ & strait & $\begin{array}{l}12^{\circ} 35^{\prime} 00^{\prime \prime} \mathrm{N} \\
043^{\circ} 21^{\prime} 00^{\prime \prime} \mathrm{E}\end{array}$ & $\begin{array}{l}\text { Djibouti, Eritrea, } \\
\text { Yemen }\end{array}$ \\
\hline Baka & Beka'e & island & $\begin{array}{l}15^{\circ} 00^{\prime} 53^{\prime \prime} \mathrm{N} \\
040^{\circ} 18^{\prime} 52^{\prime \prime} \mathrm{E}\end{array}$ & Eritrea \\
\hline Buri Peninsula & Buri & peninsula & $\begin{array}{l}15^{\circ} 14^{\prime} 13^{\prime \prime} \mathrm{N} \\
039^{\circ} 55^{\prime} 58^{\prime \prime} \mathrm{E}\end{array}$ & Eritrea \\
\hline Dahaila Kebir & Dahaila Kebir & island & $\begin{array}{l}15^{\circ} 09^{\prime} 30^{\prime} \mathrm{N} \\
040^{\circ} 08^{\prime} 09^{\prime} \mathrm{E}\end{array}$ & Eritrea \\
\hline Dahaila Seghir & Dahaila Seghir & island & $\begin{array}{l}15^{\circ} 08^{\prime} 00^{\prime \prime} \mathrm{N} \\
040^{\circ} 10^{\prime} 00^{\prime \prime} \mathrm{E}\end{array}$ & Eritrea \\
\hline Dahlak Archipelago, Dahlak Islands & Dahlak Archipelago & archipelago & $\begin{array}{l}15^{\circ} 50^{\prime} 00^{\prime \prime} \mathrm{N} \\
040^{\circ} 12^{\prime} 00^{\prime \prime} \mathrm{E}\end{array}$ & Eritrea \\
\hline Dahlak Kebir & Dehalak' Kebīr & island & $\begin{array}{l}15^{\circ} 39^{\prime} 35^{\prime \prime} \mathrm{N} \\
040^{\circ} 06^{\prime} 51^{\prime \prime} \mathrm{E}\end{array}$ & Eritrea \\
\hline Dahret & Daaret & island & $\begin{array}{l}15^{\circ} 54^{\prime} 15^{\prime \prime} \mathrm{N} \\
039^{\circ} 34^{\prime} 40 ” \mathrm{E}\end{array}$ & Eritrea \\
\hline Dar Solum & Dar Salūm & island & $\begin{array}{l}15^{\circ} 59^{\prime} 00^{\prime \prime} \mathrm{N} \\
039^{\circ} 56^{\prime} 45^{\prime \prime} \mathrm{E}\end{array}$ & Eritrea \\
\hline Dase & Dase & island & $\begin{array}{l}15^{\circ} 14^{\prime} 25^{\prime \prime} \mathrm{N} \\
040^{\circ} 07^{\prime} 43^{\prime \prime} \mathrm{E}\end{array}$ & Eritrea \\
\hline Dasetto & Dasetto & island & $\begin{array}{l}15^{\circ} 13 ’ 35^{\prime \prime} \mathrm{N} \\
040^{\circ} 07 \text { 04” E }\end{array}$ & Eritrea \\
\hline Debel Ali & Debel' Ali & island & $\begin{array}{l}15^{\circ} 05^{\prime} 09^{\prime \prime} \mathrm{N} \\
040^{\circ} 15^{\prime} 59^{\prime \prime} \mathrm{E}\end{array}$ & Eritrea \\
\hline Debir, Eiro, Er Rih & Gazirat 'Iri & island & $\begin{array}{l}18^{\circ} 10^{\prime} 22^{\prime \prime} \mathrm{N} \\
038^{\circ} 26^{\prime} 23^{\prime \prime} \mathrm{E}\end{array}$ & Sudan \\
\hline Dhu-ladhiya & Duladia & island & $\begin{array}{l}15^{\circ} 56^{\prime} 45^{\prime \prime} \mathrm{N} \\
040^{\circ} 022^{\prime} 41 ” \mathrm{E}\end{array}$ & Eritrea \\
\hline Dissei & Dese & island & $\begin{array}{l}15^{\circ} 28^{\prime} 18^{\prime \prime} \mathrm{N} \\
039^{\circ} 44^{\prime} 52^{\prime \prime} \mathrm{E}\end{array}$ & Eritrea \\
\hline Dohul & Dohul & island & $\begin{array}{l}15^{\circ} 54^{\prime} 34^{\prime \prime} \mathrm{N} \\
039^{\circ} 38^{\prime} 32^{\prime \prime} \mathrm{E}\end{array}$ & Eritrea \\
\hline
\end{tabular}




\begin{tabular}{|c|c|c|c|c|}
\hline Name as in text & Name approved & $\begin{array}{l}\text { Geographic } \\
\text { feature }\end{array}$ & Coordinates & Country \\
\hline Dohul Bahut & Dul Baut & island & $\begin{array}{l}15^{\circ} 56^{\prime} 50^{\prime \prime} \mathrm{N} \\
039^{\circ} 32^{\prime} 10^{\prime \prime} \mathrm{E}\end{array}$ & Eritrea \\
\hline Dumsuq & Jazīrat Dumsuq & island & $\begin{array}{l}16^{\circ} 32^{\prime} 27^{\prime \prime} \mathrm{N} \\
042^{\circ} 03^{\prime} 02^{\prime \prime} \mathrm{E}\end{array}$ & Saudi Arabia \\
\hline Dungunâb & Dungunāb & settlement & $\begin{array}{l}21^{\circ} 06^{\prime} 27^{\prime \prime} \mathrm{N} \\
037^{\circ} 07^{\prime} 02 \text { " E }\end{array}$ & Sudan \\
\hline Dur Ghella & Dur Ghella & island & $\begin{array}{l}15^{\circ} 46^{\prime} 27^{\prime \prime} \mathrm{N} \\
039^{\circ} 47^{\prime} 311^{\prime \prime} \mathrm{E}\end{array}$ & Eritrea \\
\hline Entedebir & Āndēber Desēt & island & $\begin{array}{l}15^{\circ} 42^{\prime} 11^{\prime \prime} \mathrm{N} \\
039^{\circ} 54^{\prime} 30^{\prime \prime} \mathrm{E}\end{array}$ & Eritrea \\
\hline Farasan Al-Kebir & Farasān al Kabīr & island & $\begin{array}{l}16^{\circ} 43^{\prime} 42^{\prime \prime} \mathrm{N} \\
041^{\circ} 54^{\prime} 39^{\prime \prime} \mathrm{E}\end{array}$ & Saudi Arabia \\
\hline Farasan Archipelago, Farasan Islands & Jazā’ir Farasān & archipelago & $\begin{array}{l}16^{\circ} 49^{\prime} 54^{\prime \prime} \mathrm{N} \\
041^{\circ} 48^{\prime} 38^{\prime \prime} \mathrm{E}\end{array}$ & Saudi Arabia \\
\hline Fatmah & Fatuma Desēt & island & $\begin{array}{l}13^{\circ} 01^{\prime} 31^{\prime \prime} \mathrm{N} \\
042^{\circ} 50 \text { ' } 56^{\prime \prime} \mathrm{E}\end{array}$ & Eritrea \\
\hline Gharib & Gharib & island & $\begin{array}{l}15^{\circ} 47^{\prime} 00^{\prime \prime} \mathrm{N} \\
040^{\circ} 27^{\prime} 00^{\prime \prime} \mathrm{E}\end{array}$ & Eritrea \\
\hline Handa & Hando & island & $\begin{array}{l}14^{\circ} 47^{\prime} 27^{\prime \prime} \mathrm{N} \\
040^{\circ} 48^{\prime} 24^{\prime \prime} \mathrm{E}\end{array}$ & Eritrea \\
\hline Hanish Archipelago & Ḩanīsh & archipelago & $\begin{array}{l}13^{\circ} 45^{\prime} 00^{\prime \prime} \mathrm{N} \\
042^{\circ} 45^{\prime} 00^{\prime \prime} \mathrm{E}\end{array}$ & Yemen \\
\hline Hant & Keda-Hando & island & $\begin{array}{l}14^{\circ} 45^{\prime} 37^{\prime \prime} \mathrm{N} \\
040^{\circ} 48^{\prime} 28^{\prime \prime} \mathrm{E}\end{array}$ & Eritrea \\
\hline Harat & Harat & island & $\begin{array}{l}16^{\circ} 06^{\prime} 38^{\prime \prime} \mathrm{N} \\
039^{\circ} 27^{\prime} 53^{\prime \prime} \mathrm{E}\end{array}$ & Eritrea \\
\hline Howakil & Hawakil & island & $\begin{array}{l}15^{\circ} 09^{\prime} 21^{\prime \prime} \mathrm{N} \\
040^{\circ} 14^{\prime} 54^{\prime \prime} \mathrm{E}\end{array}$ & Eritrea \\
\hline Howakil Bay & Bay of Hawakil & bay & $\begin{array}{l}15^{\circ} 02^{\prime} 20^{\prime \prime} \mathrm{N} \\
040^{\circ} 12^{\prime} 44^{\prime \prime} \mathrm{E}\end{array}$ & Eritrea \\
\hline Isratu & Isra-tu & island & $\begin{array}{l}16^{\circ} 20^{\prime} 00^{\prime \prime} \mathrm{N} \\
039^{\circ} 53 \text { '00” } \mathrm{E}\end{array}$ & Eritrea \\
\hline Jeddah & Jeddah, Jiddah & settlement & $\begin{array}{l}21^{\circ} 32^{\prime} 33^{\prime \prime} \mathrm{N} \\
039^{\circ} 11^{\prime} 53^{\prime \prime} \mathrm{E}\end{array}$ & Saudi Arabia \\
\hline Kad Norah & Gad Norah & island & $\begin{array}{l}16^{\circ} 06^{\prime} 00^{\prime \prime} \mathrm{N} \\
039^{\circ} 59^{\prime} 00^{\prime \prime} \mathrm{E}\end{array}$ & Eritrea \\
\hline Marsá al Marākh & Marsá al Marākh & inlet & $\begin{array}{l}29^{\circ} 25^{\prime} 45^{\prime \prime} \mathrm{N} \\
034^{\circ} 49^{\prime} 50^{\prime \prime} \mathrm{E}\end{array}$ & Egypt \\
\hline Massawa & Mits'iwa & island & $\begin{array}{l}15^{\circ} 37^{\prime} 00^{\prime \prime} \mathrm{N} \\
039^{\circ} 29^{\prime} 00^{\prime \prime} \mathrm{E}\end{array}$ & Eritrea \\
\hline Museri & Museri & island & $\begin{array}{l}15^{\circ} 29^{\prime} 12^{\prime \prime} \mathrm{N} \\
040^{\circ} 21^{\prime} 25^{\prime \prime} \mathrm{E}\end{array}$ & Eritrea \\
\hline NN045 & - & island & $\begin{array}{l}15^{\circ} 00^{\prime} 00^{\prime \prime} \mathrm{N} \\
040^{\circ} 30^{\prime} 00^{\prime \prime} \mathrm{E}\end{array}$ & Eritrea \\
\hline NN086 & - & island & $\begin{array}{l}15^{\circ} 30^{\prime} 00^{\prime \prime} \mathrm{N} \\
040^{\circ} 20^{\prime} 00^{\prime \prime} \mathrm{E}\end{array}$ & Eritrea \\
\hline
\end{tabular}




\begin{tabular}{|c|c|c|c|c|}
\hline Name as in text & Name approved & $\begin{array}{l}\text { Geographic } \\
\text { feature }\end{array}$ & Coordinates & Country \\
\hline Nocra & Nokra Desēt & island & $\begin{array}{l}15^{\circ} 42^{\prime} 00^{\prime \prime} \mathrm{N} \\
039^{\circ} 56^{\prime} 00^{\prime \prime} \mathrm{E}\end{array}$ & Eritrea \\
\hline Qummah & Qummāḩ & island & $\begin{array}{l}16^{\circ} 38^{\prime} 00 ” \mathrm{~N} \\
042^{\circ} 01^{\prime} 06^{\prime \prime} \mathrm{E}\end{array}$ & Saudi Arabia \\
\hline Sarad & Sarad & island & $\begin{array}{l}15^{\circ} 49^{\prime} 49^{\prime \prime} \mathrm{N} \\
039^{\circ} 54^{\prime} 15^{\prime \prime} \mathrm{E}\end{array}$ & Eritrea \\
\hline Sarso & Sarad Sarso & island & $\begin{array}{l}16^{\circ} 50^{\prime} 57^{\prime \prime} \mathrm{N} \\
041^{\circ} 35^{\prime} 26^{\prime \prime} \mathrm{E}\end{array}$ & Saudi Arabia \\
\hline Sawākin & Suakin Island & island & $\begin{array}{l}19^{\circ} 66^{\prime} 39^{\prime \prime} \mathrm{N} \\
037^{\circ} 20^{\prime} 13^{\prime \prime} \mathrm{E}\end{array}$ & Sudan \\
\hline Sayin & Siem & island & $\begin{array}{l}15^{\circ} 49^{\prime} 00^{\prime \prime} \mathrm{N} \\
040^{\circ} 16^{\prime} 00^{\prime \prime} \mathrm{E}\end{array}$ & Eritrea \\
\hline Segid & Sajīid & island & $\begin{array}{l}16^{\circ} 52^{\prime} 43^{\prime \prime} \mathrm{N} \\
041^{\circ} 54^{\prime} 40^{\prime \prime} \mathrm{E}\end{array}$ & Saudi Arabia \\
\hline Seven Brothers & Sawâbi’ & archipelago & $\begin{array}{l}12^{\circ} 27^{\prime} 49^{\prime \prime} \mathrm{N} \\
043^{\circ} 24^{\prime} 39^{\prime \prime} \mathrm{E}\end{array}$ & Djibouti \\
\hline Shadwan & Jazīrat Shākir & island & $\begin{array}{l}27^{\circ} 30^{\prime} 05^{\prime \prime} \mathrm{N} \\
033^{\circ} 59^{\prime} 21^{\prime \prime} \mathrm{E}\end{array}$ & Egypt \\
\hline Sheik Said & Shēk Seyd & island & $\begin{array}{l}15^{\circ} 35^{\prime} 34^{\prime \prime} \mathrm{N} \\
039^{\circ} 28^{\prime} 42^{\prime \prime} \mathrm{E}\end{array}$ & Eritrea \\
\hline Shumma & Shumma & island & $\begin{array}{l}15^{\circ} 32^{\prime} 14^{\prime \prime} \mathrm{N} \\
040^{\circ} 00^{\prime} 10^{\prime \prime} \mathrm{E}\end{array}$ & Eritrea \\
\hline Taba & Ţābā & settlement & $\begin{array}{l}29^{\circ} 29^{\prime} 31^{\prime \prime} \mathrm{N} \\
034^{\circ} 533^{\prime} 45^{\prime \prime} \mathrm{E}\end{array}$ & Egypt \\
\hline Taulud & T'walet Desēt & island & $\begin{array}{l}15^{\circ} 36^{\prime} 13^{\prime \prime} \mathrm{N} \\
039^{\circ} 27^{\prime} 56^{\prime \prime} \mathrm{E}\end{array}$ & Eritrea \\
\hline The Brothers Islands & Al Ikhwān & archipelago & $\begin{array}{l}26^{\circ} 18^{\prime} 53^{\prime \prime} \mathrm{N} \\
034^{\circ} 50 ’ 41^{\prime \prime} \mathrm{E}\end{array}$ & Egypt \\
\hline Tiran & Jazīrat Tīrān & island & $\begin{array}{l}27^{\circ} 56^{\prime} 25^{\prime \prime} \mathrm{N} \\
034^{\circ} 33^{\prime} 40^{\prime \prime} \mathrm{E}\end{array}$ & Egypt \\
\hline Umm es Sahrig & Um-les-Sahrig & island & $\begin{array}{l}15^{\circ} 04^{\prime} 22^{\prime \prime} \mathrm{N} \\
040^{\circ} 29^{\prime} 51^{\prime \prime} \mathrm{E}\end{array}$ & Eritrea \\
\hline Umm es Seil & Umm es Seil & island & $\begin{array}{l}15^{\circ} 03^{\prime} 39^{\prime \prime} \mathrm{N} \\
040^{\circ} 14^{\prime} 25^{\prime \prime} \mathrm{E}\end{array}$ & Eritrea \\
\hline Zabargad & Jazīrat Zabarjad & island & $\begin{array}{l}23^{\circ} 36^{\prime} 39^{\prime \prime} \mathrm{N} \\
036^{\circ} 11 ’ 46^{\prime \prime} \mathrm{E}\end{array}$ & Egypt \\
\hline Zifaf & Zufăf & island & $\begin{array}{l}16^{\circ} 42^{\prime} 43^{\prime \prime} \mathrm{N} \\
041^{\circ} 46 \text { ' } 311^{\prime \prime} \mathrm{E}\end{array}$ & Saudi Arabia \\
\hline Zimmer, Jazirat Sumayr, Sumayr & Jazīrat Zamhar & island & $\begin{array}{l}16^{\circ} 17^{\prime} 59^{\prime \prime} \mathrm{N} \\
042^{\circ} 19^{\prime} 43^{\prime \prime} \mathrm{E}\end{array}$ & Yemen \\
\hline Zubair Archipelago & Jazā'ir az Zubayr & archipelago & $\begin{array}{l}15^{\circ} 05^{\prime} 00^{\prime \prime} \mathrm{N} \\
042^{\circ} 08^{\prime} 00 ” \mathrm{E}\end{array}$ & Yemen \\
\hline
\end{tabular}

